
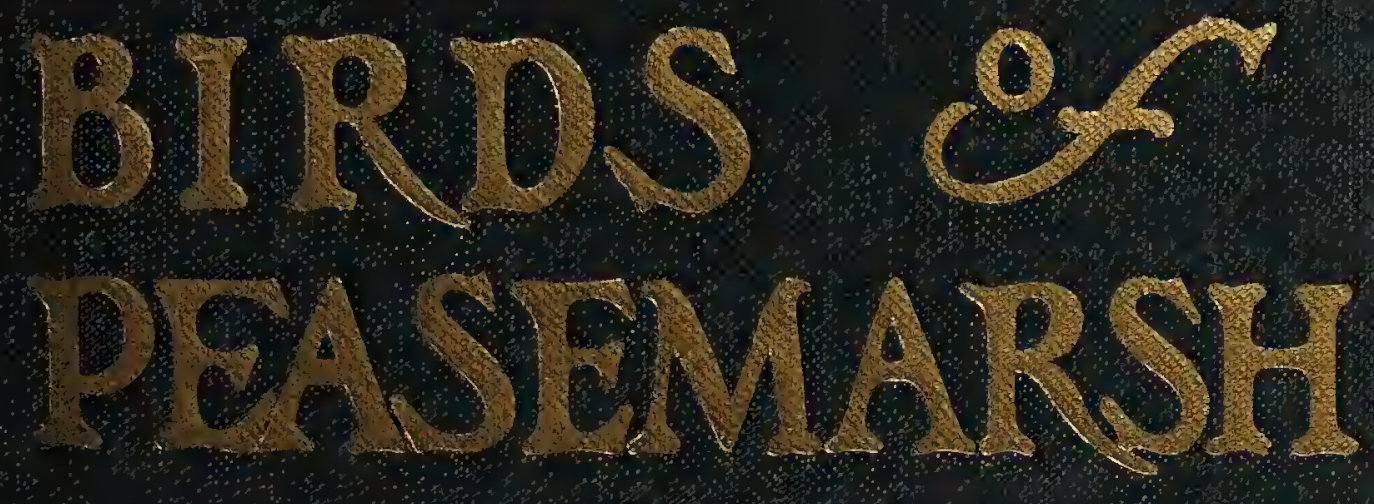

\title{
b.
}

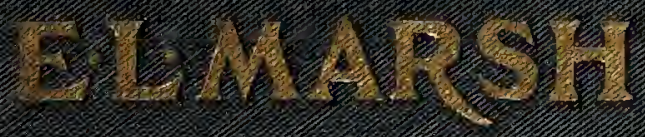





\section{BIRDS OF PEASEMARSH}



Digitized by the Internet Archive in 2019 with funding from Kahle/Austin Foundation 


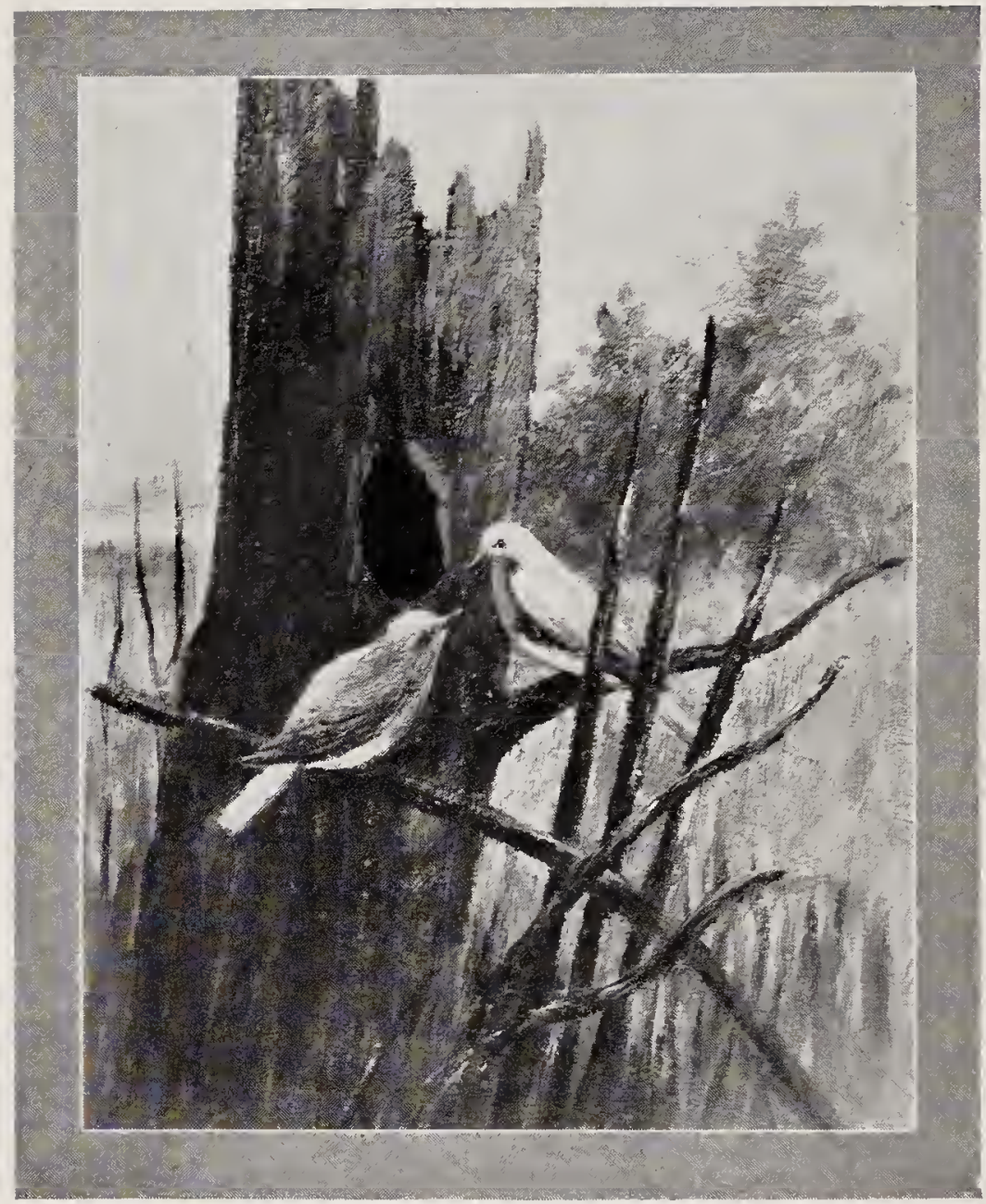

Choosing a home. 


\title{
BIRDS OF PEASEMARSH
}

\author{
By \\ E. L. MARSH
}

ILLUSTRA TED

By Photos and Sketches from The Sanctuary

THE MUSSON BOOK CO., LIMITED Publishers

Thomas J. Bała Library

TRENT UNIVERSITI

PETERBOROUGH, ONIARIC 


$$
\begin{gathered}
Q_{1685.2 .05} 0_{5} M_{3} \\
1919
\end{gathered}
$$

Copyright Canada, 1919
THE MUSS ON BOOK CO., LIMITED
Publishers 


$$
\begin{gathered}
\text { To } \\
\text { the memory of } \\
\text { my Mother and Father, } \\
\text { the founders of } \\
\text { Peasemarsh. }
\end{gathered}
$$


F the Georgian Bay region, the author of "Birds of Ontario in Relation to Agriculture," who has studied bird life throughout the Dominion, has said that it is one of the greatest of bird homes and one of which but little has been written, and that greater notice should be given to the protection of birds in this part of Canada. Concerning Peasemarsh Sanctuary, Mr. Nash has carried out this suggestion, interesting himself in all our questions, from the mysterious disappearance of Indigo Bunting's eggs to the protection of the Grouse in the bush, or the Heron on the pond. Only those who are endeavoring alone in far-away places to protect the feathered creatures can realize how much such an interest that never fails can give to the Sanctuary. 


\section{CONTENTS}

CHAPTER I

PAGE

Introduction; The Orchard in June - - 1

CHAPTER II

The Value of Birds - - . . . . . - 11

CHAPTER III

The Adaptability of Birds; The Chimney SWIFT - . . . . . . . . 21

CHAPTER IV

Barn Swallows and Their Use of Old Buildings _ . . . . . . . . 29

CHAPTER V

The Barn Swallow's Relatives - - - 37

CHAPTER VI

Birds that Nest in Hollow Trees - - - 43

\section{CHAPTER VII}

Thrushes, Thrashers, Waxwings, Kinglets,

Warblers, Vireos - - - - - - - 59

CHAPTER VIII

Flycatcher Family: Laris, Tanager - - - 71

\section{CHAPTER IX}

The Family of Finches and Sparrows - - 77 
Meadowlark, Bobolink, Oriole, Blackbird,

Cowbird -

\section{CHAPTER XI}

Goatsucker Family; Cuckoo Family; Pigeon

FAMILY - - . - - - - . - - 101

\section{CHAPTER XII}

Resident Birds - - - - - - - - 107

CHAPTER XIII

Resident Game Birds - - - - -

CHAPTER XIV

Birds of Shore and Marsh - - - $\quad$ - 121

CHAPTER XV

Shore Birds and Waders - - - - - - 129

CHAPTER XVI

Wild Geese, Swans and Ducks - - $\quad-\quad$ - 139

\section{CHAPTER XVII}

Migration of Birds -

CHAPTER XVIII

Need of Protection for Birds - - - - - 157

\section{CHAPTER XIX}

Bird Enemies -

CHAPTER XX

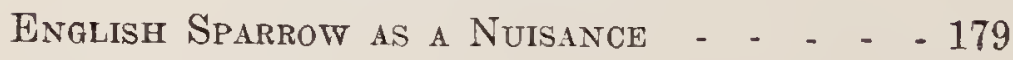


CHAPTER XXI

PAGE

Attracting Birds by Food, Drinking Foun-

tains and Nesting Material - $\quad-\quad$ - 189

\section{CHAPTER XXII}

How to Make and Hang Nest Boxes - - - 197

\section{CHAPTER XXIII}

Nesting Stites -

\section{CHAPTER XXIV}

Bird Clubs and Sanctuaries - - - - $\quad$ - 219

\section{CHAPTER XXV}

"Little Feathered Brothers" - - - - - - 229 



\section{LIST OF ILLUSTRATIONS}

Choosing a home - . - . - . - Frontispiece

(1) The Bluebird's nest inside the nest box; (2) The burrows of the Bank Swallow; (3) Temporary chimney erected for the Swifts - - - Facing page

(1) Flicker making an entranee; (2) A home which affords a better riew; (3) Young Flicker at entrance - . . . . . - Facing page

(1) The rrearing of the Oriole that has withstood the winter's storms; (2) The Vireo's nest: note loops of birch bark - . - . - . Facing page

The home of the Grouse - - - - Facing page

(1) A fox hole in the bank; (2) One red squirrel less; (3) Indigo Bunting 's nest - - Facing page 169

(1) Nest box attached to board and uailed to tree; (2) Roof, with plug to hold it in place; (3) Nest box, with straight hollow; (4) Nest box in Fig. 2, with roof adjusted - - - . - - Facing page

Photos from the Sanctuary-(1) Father Bluebird at nest box; (2) The Bittern on her nest; (3) Baby Mourning Doves; (4) Baby Bluebird the day it came out of nest box in Fig. 1 - - - Facing page 219 



\section{Birds of Peasemarsh}

\section{CHAP'TER I}

THE ORCHARD IN JUNE

A four o'clock every morning in June a glorious concert commences in the orchard. From that early morning hour until the Vesper Sparrow sings his last good night there is scarcely a moment without music. One of the earliest singers is the Song Sparrow, but the most persistent is the little Wren. Beautifully these blend with other morning songs, some at our very door, some far down at the foot of the orchard. The Brown Thrasher sings his good morning from the top branch of a tall maple, the whistling note of the Oriole comes from the elms, the Meadowlark calls from the edge of the orchard and Bobolink's silvery notes come over the meadow.

When one considers the number and variety 


\section{B I R D O F P E A E M A R H}

of songs one is constantly hearing one wonders that the birds can do anything but sing. But they work while they sing. The little Wrens have hunted high and low for the right kind of sticks to carry into their nest boxes. To-day one little Jenny Wren came home with a very long hen's feather and judging by the triumphant singing of her mate it must have been a rare treasure. Already the Flickers in the hollow tree have a young family to feed. The appetites of the young Robins are increasing every day, and to fill the little open mouths the parent birds are diligently hunting in the gardens.

The Warblers are busy going over the trees. Judging by the number of sweet warbling voices one hears the Green and Yellow Warblers are especially numerous, so they must have had a safe flight from their winter quarters far across the Gulf of Mexico. Many other members of the Warbler family have been seen. One day the Black-throated Green Warbler came to the wood-pile, a place which seems to have a great fascination for all the smaller birds.

A pair of Kingbirds have come recently to 


\section{B I R D OF PEA SEM A R H}

the orchard and this is well, for they will help keep off the Crows and Blackbirds. Until they decided to settle here, the Robins were the only ones plucky enough to attempt to drive out such bird-nesting marauders, which have grown too numerous of late for the welfare of the song birds. Up near the house one hears the insistent note of the Kingbird's cousin, the Phoebe, and from the wooded bank at the foot of the orchard comes the note of the Wood Peewee. The Bank is also the home of Chickadee and Nuthatch and some of our bright plumaged birds have found it a favorite spot. A Scarlet Tanager seems to have chosen a tree there, while another is often seen in a thicket left for the birds in the centre of the orchard. The Goldfinches are now numerous and add their sweet voices to the chorus, the Purple Finch and the Indigo Bunting are heard in bush or tree and the voice of the Yellow-billed Cuckoo comes now and then from the old Spy trees that edge the hill.

The Red-headed Woodpecker, not Downy with only the red spot, but the Woodpecker which wears red feathers on his entire head, is heard near by, but his home is in the woods 


\section{B I R D O F PEASEMARS H}

below the bank. Downy lives nearer and the sound of his tap, tap, tap reaches up to the window. From near the barn comes the liquid note of the Bluebird as he keeps watch over his nest box. He has had a trying time, for some European Sparrows have gained a foothold about the barn and have worried him incessantly.

In the late afternoon one hears the musical twitter of the Swallows and the Swifts circling about high above the tree tops. Then when night comes and the last bird song has ceased, there can be heard far in the distance the Whippoor-will and the Night Hawk. The others had the day, to these belong the night and the night flying insects. So every hour the orchard has its bird voices. What would it be without the beautiful plumage, the sweet songs, and more than all the good deeds of the feathered creatures?

June was by no means the beginning of their songs. They had been there for weeks, some coming before there was a sign of April foliage, before even the April showers had washed away the snow banks, and all through those discouraging days they trilled and whistled and 
sang that Spring was on her way. Thus they cheered the human beings who waited through snow and rain and cold for the slow coming of springtime, for birds do not forget any spot where it is possible to nest. They go where Spring comes late. Sometimes it is late in coming to Peasemarsh here on the western shore of the Georgian Bay at the foot of the Blue Mountains, but the birds do not despair; they are the same bright guests here as in all places within their range.

Always this has been a favorite spot for birds. They were here before the first white man came this way. One reads of them in the very few stories and legends that have come down to us from the Indians that once peopled this country. The Indians must have studied the habits of the birds in the very spot where they are singing in the orchard, for just under the hill was once an old Indian village, and the trail leading from it, to distant camps on the bay, crossed what is now the orchard and the meadow.

So far as we know, the Indians, going back and forth from their village, passed under the old elm where now hangs the Bluebird house. 


\section{BIRDS OF PEASEMARSH}

There were Bluebirds then, as there are now, but the Indians called them "specks of sky," and fragments of a legend have been indirectly handed down. It seems that when the birds received their clothing from the Great Spirit, the Bluebirds, having a maimed one in their family, were delayed on their way and arrived at the spot where the Great Spirit had sent the clothes just after all the feathers had been chosen by other birds. Then the Great Spirit said, because they had not deserted their weak birdling they should be clothed in fragments of the covering of his tent in the sky, and bits of the blue came down, taking the form of feathers, and sunset shades for their breasts.

The Bluebirds chose the house on the elm as their home one cold April morning, just after it was put up, and they have held it ever since, though the Sparrows tried their utmost to put them out. Judging from their apparent satisfaction at finding it, they had had a long weary search for a safe and suitable nesting place.

It was a pair of tiny Wrens that first drew our attention to the need of nest boxes for the birds. For several years these Wrens had nested just under the roof of the front veran- 


\section{B I R D O F P E A S M A R S H}

dah where the weather beaten wood, beginning to decay, left a crevice. On June mornings their singing sounded through the whole house. They never seemed to be alarmed at any noise from inside, but rather to enjoy it, and at the sound of the piano they were overwhelmed with delight. During each summer two broods were successfully hatched and added their little voices to the sweet Wren chorus.

Then it happened that early one year, before they had come back from the south, the verandah had to be repaired. New wood took the place of the old, mouldering rafter where the Wrens had nested, and this was freshly painted. Upon their return the Wrens inspected it, but alas, the little hollow and the old, mouldering wood were gone, and they were suspicious of the newness that had taken its place. They would not nest there again. They did not leave the house, however, but flitted back and forth round the back door, where there was no new wood and no fresh paint. Before long it was discovered that they were nesting in a rag bag that hung on the back of the door in the summer kitchen, and were going in and out through the open window. In that nest in the 


\section{B I R D OF PEASEM A R H}

bag they hatched out their families undisturbed by the commotion of the summer cooking; frequently they alighted on the table among the dishes. Very neat housekeepers they were. When they had gone in the fall the rag bag, except for the little nest of sticks, was as clean as before it had been occupied.

The next summer they made a nest just under the roof of the back verandah, but here they came to grief. It was a year when beechnuts were scarce and the red squirrels came to the barns and the trees about the houses for food to fill their larders. When the little Wrens were hatching their second brood a squirrel found them out. The frantic scolding of the birds brought out the occupants of the house, but it was too late to save the eggs. The squirrel had dined, and with egg smeared over his whiskers and paws had made his way off. We could only condole with the bereaved birds and promise them that if they would stay with us we would find some way of providing them a safe nesting place. The little house put up for the Wrens the next spring was but the beginning of what could be done for the safety of the feathered tenants. Three years have passed 


\section{B I R D OF PEASEMAR H}

since then. Each year there has been something fresh to do for the birds. Each year has brought back their children and grand children, and now bird houses dot the grounds. 



\section{CHAPTER II}

THE VALUE OF BIRDS

$7 \mathrm{HE}$ tragedy that came to the little Wrens is but the tragedy that has come to birds all over the country far and wide, wherever they have sought to make their homes. Time and again they have been forced to leave the spot they had chosen and search out distant nesting places. If people could realize the loss to garden and orchard and farm when even one pair of useful birds gives up housekeeping there, the loss to the whole country should one little family of nestlings be wiped out, men, women and children would work together to keep the feathered creatures with them.

The number of injurious insects destroyed by birds is beyond estimate. Anyone doubtful of the good they do should watch a pair of tiny house Wrens feeding their young nestlings and try to count the number of times in one hour that they come to the nest with food, sometimes not only with one insect but with a beakful. About thirty times an hour is a low 


\section{B I R D OF PEASEMAR S H}

average from one count made here. Multiply that by the number of hours they work; they start about four o'clock in the morning, and the babies' supper is not over until twilight. Multiply again by the number of days they are there and add to this what the mother and father must devour. Then, later, when the babies are grown and hunting for themselves and the mother and father are raising a second family, add what the young family must catch. And if a third family be raised, as is sometimes the case, if conditions have been favorable and the nest has been safe, add what the second family must hunt for themselves while the old birds are feeding the third nestlings. One must not forget that a family of Wrens consists of from four to seven or eight, which makes from eight to sixteen birdlings in the two families that are hunting insects and eating as much as they possibly can, which is an astonishing amount for their size. The answer to the problem will be a long array of figures, and it indicates the number of insects less in the garden because Jenny Wren built her nest there and was left in peace to rear her family. 


\section{B I R D OF PEASEMARSH}

We had never considered diminutive Jenny a potato bug eater, but last summer a wren house was placed in a tree which grew beside a small potato patch. Until the Wrens had flown no bugs injured those potato plants. Other birds may have helped to keep them down, but one thing is certain, the Wrens appeared to be taking a great many when very small. They would not, of course, take them when full grown, but they seemed to give them little chance to grow. It is not wise to lay down rules and regulations for any species of birds. They seem to be possessed of individuality and circumstances may alter their habits. It is wonderful how far their sharp little eyes can see. That same summer a few sweet peas grew beside the kitchen door. While all went well with those sweet peas the Wrens took no interest in them, they flew in other directions for their food. But one morning little green insects appeared on the vines and directly the Wrens were there.

Some bird landlords assert that there are objections to Wren neighbors, that they prevent other birds from nesting near them, but so far we have not known them to do anything worse 


\section{B I R D O F P E A E M A R S}

than monopolize more bird houses than they require. Apart from the value of the Wrens as insect destroyers they are charming neighbors. Their soft brown feathers and their sharp bright eyes make them very attractive creatures as they flit about the door and windows, and, more than all, their songs are a delight. Being of so confiding a nature they will sing very near to us. Last year a family of young Wrens hatched in a house near the wood shed, took their singing lessons on the wood pile, sending out from that dull, humble spot a chorus of sweetest song.

The Wren is but one of the many birds that would gladly come nearer if they found it safe to do so. There are birds that gather their food from the injurious grubs and insects of the ground, birds that live on the flies, midges and other pests of the air, and some, like the Barn Swallow, that devour the flies that are such a torment to horses and cattle. There are birds that work among the leaves of trees and shrubs, and birds that hammer away the loose bark of the tree trunks and branches, searching out the insects from underneath. Without birds the fruit grower and the farmer 
BIRDS OF PEASEMAR H

would be defeated by hordes of insect pests that would devour the trees and the crops. The cutworm alone which, by cutting the stalk at the surface of the ground, destroys every plant it attacks, if allowed to increase, would menace the production of the most fertile acres. $\mathrm{Na}$ ture, however, has given birds that feed upon the ground some mysterious way of locating these worms hidden under the ground, and strong, sensitive beaks with which they dig them out.

The agricultural value of birds has long been recognized in England. In no country are they more carefully protected, and probably in no country has there been less destruction of crops by insect pests.

In New Zealand, where wingless birds abound, they have been given sanctuaries where they are protected. Had this not been done they would have been forced to hide away in some dense thickets, and would soon have become extinct as they could not long have escaped the wild creatures that prey upon them, or the gunner and his dog. The guardian of these sanctuaries in writing of the wingless birds as insect destroyers, remarks that, "If 


\section{BIRDS OF PEASEMARSH}

they were difficult to get fruit growers would be quite keen about them."

So often the real use of wild creatures is not realized until it is too late. In understanding and protecting the birds there is no time to lose, for many have been rapidly decreasing in numbers in the very districts where they are most needed.

There is a story of a bird landlord who studied the habits of birds and endeavored so successfully to give them what they required that they came in thousands to his estate. There is also the story of the summer when an insect plague came to that country and every green thing round about was devoured, yet this estate remained as green and verdant as ever. The birds that he had attracted about him protected him from the insects that were sweeping through the land.

In Salt Lake City there is a monument, and engraven on it are the Sea Gulls coming to the rescue of a stricken people. A horde of black crickets had come down upon the land devouring every green thing, and leaving the fields of bountiful crops bare as the desert. Suddenly, from no one knew where, there came 
B IRDS OF PEASEMARSH

down into those fields thousands and thousands of Gulls, and the march of the devastating horde of crickets ceased. As they had devoured the crops the Gulls devoured them. Later the monument was erected to commemorate the event and as a symbol of the protection which the people would give to the Gulls that had saved them from starvation.

There are many instances where during insect plagues birds have come from all the country round and saved the infested district. If, however, the insect plague comes at the nesting season the birds do not gather in flocks and fly to distant places. The particular spot where birds are nesting has the advantage. The birds are always there.

If one had watched in the orchard as well as listened that June morning one would have seen the Vesper Sparrow, the Song Sparrow and all their cousins visiting the weed patches and devouring seeds. Just at that time they were eating dandelion seeds that would have blown in the wind and spread over the lawn. Later, as seeds ripen, they eat the seeds of more injurious weeds. One would have seen also that the Thrush, having finished his song in the 


\section{B I R D O F P E A E M A R H}

tree top, descends to the ground and searches for insects. The Oriole is hunting among the branches for caterpillars, the Meadowlark and the Bobolink are hunting for worms and beetles in the meadow, the Robin is digging them up in lawn and garden, while the Cuckoo does not hesitate to pounce upon a full grown hairy caterpillar, a thing at which most birds would look askance. The Warbler, Nuthatch, and Chickadee keep innumerable insects off the trees, neglecting neither trunk, branches nor leaves. Very thorough is their work. It seems all the same to these birds whether they are clinging to the branch upside down or right side up so long as their sharp little beaks can reach insects spied out by their sharp little eyes. Each one among them is an expert in its work. The Kingbird and Phoebe and the Wood Peewee are dining on winged insects, and the members of the Finch family are helping the Sparrows with the weed seeds. The Bluebird is busy gathering his particular choice of insects. The Swallows are hunting the flies, and the little black Swifts, circling about high above the elms, are busy with the insects of the air. 


\section{BIRDS OF PEASEMARSH}

The habits of one species of our insectivorous birds alone shows that, as well as being a chorus of songsters, the feathered creatures are an army of workers. The birds cannot answer in words the question, "What good are they?" which, strange to say, is still sometimes asked. But anyone who takes time to watch them for a few moments has a very forceful answer, though a silent one, "Always deeds speak louder than words." 



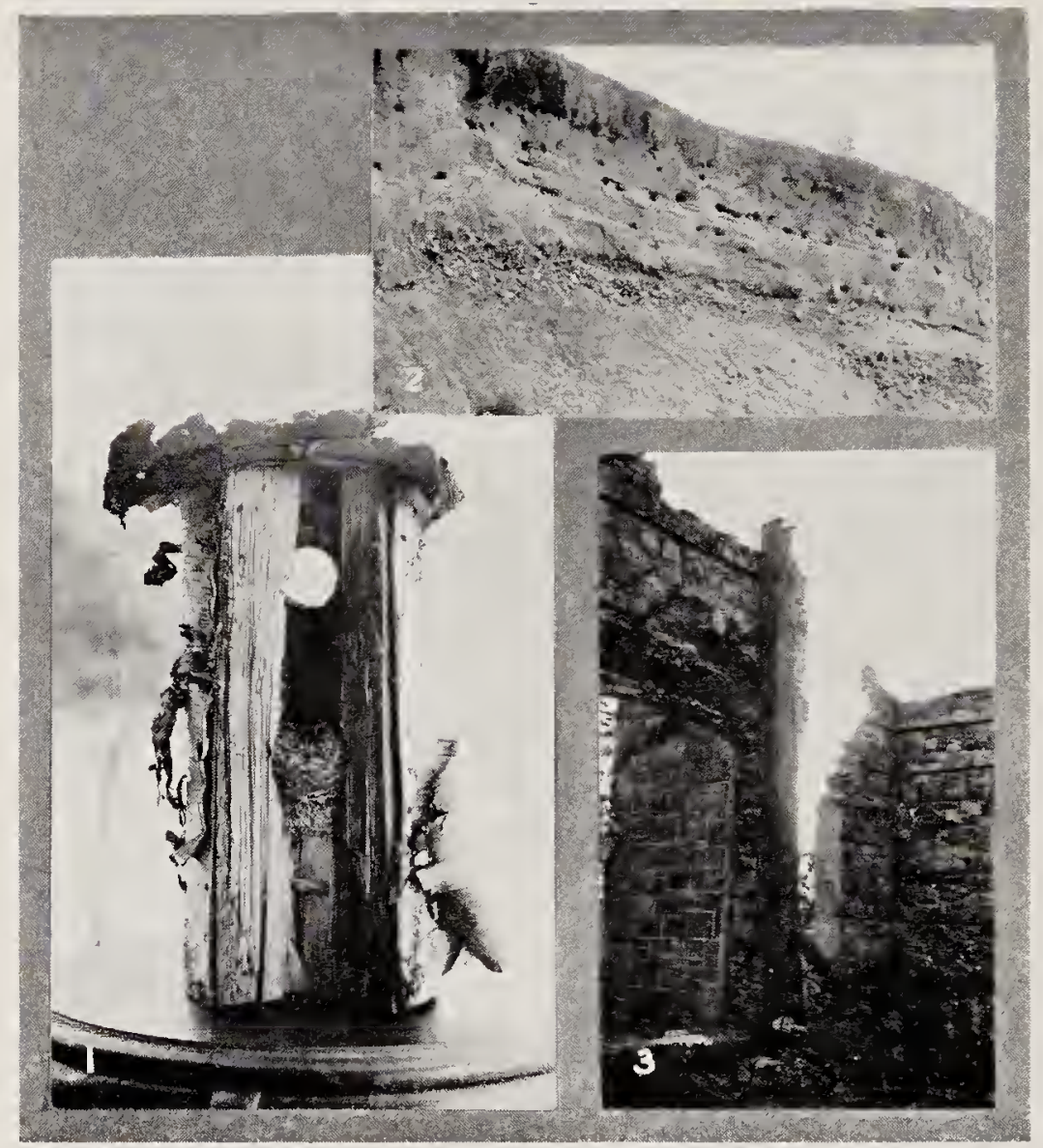

1. The Bluebird's nest inside the nest box, (Page 17t.)

2. The burows of the Bank Swallow. (1'age 35.)

3. Temporary chimmey erected for the Swifts. (Page 23.) 


\section{CHAPTER III}

THE ADAPTABILITY OF BIRDS-CHIMNEY SWIFT

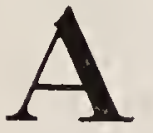

VISIT to any country home where trees are numerous and birds have been protected shows how wonderfully they have adapted themselves to human habitations and accepted any protection that human beings will give them. They are found nesting in the stable, in the barn, along the rafters, in the sheds, in the trees about the barn and house, in protected fence corners, in the garden, on the vines growing over the house, under the roof of the verandah and in the chimney.

At this very place less than three hundred years ago the birds had not seen a human habitation save those of the Indians, and had never been forced to leave their natural nesting places in the trees or the caves, among the wild ferns and grasses, or beside the silent streams and lakes where no gun had ever been heard. 


\section{BIRDS OF PEASEMARSH}

Now, except in distant parts, the lonely woods and the caves have been taken from them and the streams and lakes are no longer safe and silent. The birds must either follow the retreating woods farther and farther back, or nest near the homes of man. Many of them did not require three hundred years to adapt themselves to the changed condition and the surroundings of the white man. They gave him their confidence when he first came among them and where that confidence has not been abused the birds have made their homes for years.

One of the first birds to leave its native haunts and come to the habitation of man was the Chimney Swift. There is great danger that it may be one of the first to disappear. For most people it has already become but a memory. For some it is not even a memory, but only a romance as unreal as the tales of elves and fairies. For some, however, it is still more than a romance and more than a the chimney as surely as the coming of spring. memory, it is a real living being that returns to Those rare ones are they who have remained in some old home, with its weather-beaten 
B I R D S OF. PE A S E A R S H

gables, its shingled roof, and its chimney that stands high above the tree-tops. Down beneath the chimney is the old wood fire-place, old wood furnace, or huge wood-stove. It is a big broad chimney with plenty of room to accommodate the Chimney Swift's numerous family and still leave space enough for the old ones to move about and bring food to the little ones. In such a chimney live the Chimney Swifts, Chimney Swallows they are frequently called, though they do not belong to the swallow family.

All the bright, hot June days they give little evidence of their presence there, but at twilight, when the sunset sky is gold and crimson behind the elms, they dart out and circle widely round, high above the chimney and the tree-tops, sometimes darting downwards and then up again, then down the chimney, then out again, as if they were playing some absorbing bird game. In reality they are catching, on the wing, supper for all the hungry nestlings. When they dart down the chimney there can be heard in the room from which it opens the chatter of the little ones as the mouths open for the midges, mosquitoes and various other 


\section{B I R D OF PEA S M A R H}

insects their mother is bringing. At intervals this chatter can be heard until late at night, for in hot weather the Chimney Swifts catch their food at night and in the early morning. In the cooler days, however, they may be seen hunting for insects during the day.

A Chimney Swift's nest is supposed to contain four or five eggs, but on looking down our old chimney one year, no less than ten were counted. Whether they all hatched out we do not know, but one thing is certain, the nest was full to overflowing, for one wee little black Chimney Swift was crowded out and, tumbling over the edge, slipped down into the stove pipe, the accident causing such a twittering and chattering and fluttering among them all that the pipe had to be taken apart and the baby Chimney Swift restored to its family, otherwise the family of humans would have had but little sleep that night.

"Why do you let them stay?" some people ask. "Are they not a nuisance?" They are not a nuisance and why should they not stay? Is it not they who catch the mosquitoes and night insects, thus making our verandah a restful place on the hot summer evenings? 


\section{B I R D O F P E A S M A R S}

One winter, when the Swifts were away in the south, the house was burned and only the stone wall left standing. The Swift's chimney was gone. In the early spring when the birds were coming back we began to think about our dusty little friends and wonder where they could go. The children were in despair. They said the Swifts might think we had burned the house down on purpose so they could no longer nest with us. Such a misunderstanding with our old and valued tenants, the Chimney Swifts, would never do. Something had to be done.

Finally it was suggested that a chimney should be made of lumber and fastened up in the same place. This was done, four pieces of lumber being nailed together in the form of a square. As these boards were thirty feet long, this tall chimney, when resting on the top of the remains of the furnace in the cellar, reached up above the wall in the very place where the Swift's chimney had been. A little fire was put in the furnace, so that the smoke, escaping through the long board chimney, would give it a blackened appearance that might make the birds feel more at home. It was not quite so roomy as the brick chimney had been, but we 


\section{B I R D OF PEASEMAR S H}

had faith in their adaptability and felt sure they would be satisfied and glue their little nest of sticks on the inside wall, as they had done in the old chimney.

No birds have a more remarkable way of building their nests. They break the twigs, of which they are made, from the trees, and glue them to the chimney with saliva from their mouths. If a hot fire should be built after the nest is finished there is danger that the glue will melt and let it down. With the memory of the Chimney Swifts comes the memory of cool June evenings when the fire was not started for fear of bringing some calamity to the nest or nestlings in the chimney above.

Poor little Chimney Swifts, they are all too few! Modern roofing, modern chimneys and people with most precisely modern ideas as to heating are fast forcing these innocent little creatures out from among us. And where can they go? When the land was settled by the white man they came to his chimneys from the caves and the hollow trees, where they had natural chimneys. Now the white man has disposed of those natural nesting places. If he no longer allows them a place in his 


\section{B I R D OF PEASEM A R H}

chimneys he is driving them away forever.

The Chimney Swift has an undying place in story and in romance. The very mention of the name recalls the tales of childhood and brings up visions of buildings old and moss grown. To preserve a few chimneys adapted to their needs will save them for the children of the future, so that they, too, may watch at twilight for the little black creatures that dart upwards from some old chimney and circle about above the tree-tops as they catch their evening meal. 



\section{CHAPTER IV}

THE BARN SWALLOW AND ITS USE OF DESERTED BUILDINGS

7 HE Barn Swallow is another bird that has adapted itself to human habitations. As its safe nesting places disappeared, it came to man to make its home, plastering its tiny nest on some nook or corner of his buildings. The nest of the Barn Swallow, is very wonderfully made. Unfortunately the greatest builders often have the greatest difficulties. The useful, beautiful, unoffending Barn Swallows have had such a hard time among us that a lecturer on birds recently made the statement that they were becoming extinct.

Because they are beautiful birds, have a confidential nature, and build about the barns and out-houses they have been, in past days, a mark for boys who knew no better than to shoot them, proud of the number they were able to bring down. Bird-lovers have done much to lessen this evil. Children are learning the benefit of birds and are becoming interested 


\section{B I R D OF PEASEMARSH}

in the protection of all wild life, so that instead of boasting of the number of birds they have shot they tell of the number of nests they are protecting. Not long ago a fine marksman was heard to say, "Just to think I used to shoot the Swallows! I did not know what a sin it was." But he is making it up to the Swallows now, for he is protecting them from the annoyance of European Sparrows, as well as from other enemies.

The Swallows can nest about the stone foundations of the barn, where they are comparatively safe from cats and red squirrels, but the Sparrows they cannot evade. These will deliberately sit about and watch the hard working Swallows build their nest. The chances are they will take it away from them as soon as it is finished. If, however, the Swallows hold their own with them, they are likely to throw out the eggs, or still worse, the little ones as soon as they are hatched, and the poor Swallows are forced to build again for their second family, or leave altogether, as they frequently do. If they succeed in remaining through the nesting season it is very likely that when they return in the spring they will 


\section{B I R D O F P E A S E M A R H}

find that while they were away the Sparrows took possession, holding the nest even though they may not want to nest there.

And what a wonderful nest this European Sparrow has usurped, the sort of a nest he could never have built for himself. No one could watch a Swallow build without the greatest wonder and admiration. They can plaster a nest on a beam or wall so firmly that it will remain a fixture for years. Down in the mud puddles they find their plaster, and their beaks are their trowels. They will work away in the puddles getting mud of the exact constituency required. Then away they go, plaster it on that wonderful little structure, and back they come for more. If the season is very dry they can be greatly helped, and sometimes attracted to a place, if some mud is kept near, on some old boards or in a broken box.

Though it may take time, ingenuity and patience to protect the Barn Swallows, it is well worth while, for every particle of food they take is lessening our insect pests. If forced out of our barns and sheds to nest they will be at the mercy of their natural enemies, larger and more deadly than European Sparrows, and 


\section{B I R D O F PEA S E A R S H}

when it is too late we shall awake to the fact that there are no more fork-tailed Barn Swallows.

Often these birds search out some old deserted house or barn and there build their nests. This is for safety rather than from preference, for they seem to be naturally sociable creatures. Through sad experiences they have learned that in occupied buildings they are not always unmolested.

The farther away the Swallows are driven the more flies there will be about the buildings. Anyone who has the slightest doubt that they are the best fly catchers should watch them when they are feeding their young. Back and forth they flit, catching flies to fill the open mouths. Each day they are bringing comfort to the four-legged creatures of the barn yard.

In the old horse stable here we have had, for many years, a Barn Swallow's nest plastered on the side of one of the beams. Other pairs nest about the old sheds, but this pair have clung to their nest in the horse stable. Each year they have hatched twice. Last year they brought out the first family in safety, and it was a family any Barn Swallow might well be 
B I R D OF PEASEMAR S H

proud of as they flitted about the yard catching flies for themselves. But they came to grief with the second lot. These were found one morning lying dead on the stable floor. A pair of European Sparrows that all summer had dodged our efforts to get them must have done the deed. So the next year we shall have one family of Swallows less to catch the flies in our barnyard.

In a stable not far away the fork-tailed Barn Swallows had nested in safety high above the horses for a number of years. Then came a summer when a new chore boy appeared, and scarcely had they begun to hatch their first nestlings, when down came the nest, and the little broken eggs lay scattered on the stable floor. The Swallows would not go into the stable again all summer, and all summer long the horses were tormented by a horde of flies. Had that boy, when a child at school, heard something of the value of birds and learned to regard them as friends and neighbors that Swallow's nest would never have come down, and the old farm horses could have taken their meals in peace.

It is little wonder that such experiences make [ 33 ] 


\section{B I R D OF PEASEMAR S H}

the birds go to the buildings unoccupied by man. In looking through an old deserted church that years ago had been the centre of an Indian mission, it was found to contain eight nests of fork-tailed Swallows that had found their way in through some open niche.

"So the old church is still doing missionary work," said the bird lover who lingered there.

One of the most picturesque homes of the birds is an old house on a foothill of the Blue Mountains, overlooking what was once an Indian battle ground. Outside the steep roof, picturesque gables and quaint knocker; inside, the carved staircase, broad fireplace and wall cupboards in unexpected corners proclaim its age. It is the boyhood home of one of Canada's brilliant men who passed away only a few years ago. For some time the old home has been unoccupied by human beings, but the feathered creatures had found it out. Little Wrens nested in crevices about the buildings and fork-tailed Swallows plastered their nests under the eaves. One night a violent storm of wind and rain broke a pane of glass in one of the upstairs windows. A pair of Barn Swallows that Sparrows had chased from a near-by 


\section{B I R D OF PEASEMARSH}

barn found it, and built their nest inside the room, just over the door. This room proved a haven of safety for the birds. No cat could reach it, no red squirrels could run up the window pane to the hole where the birds went through, and carry off the nestlings. No nest robbing creature could enter there. There was nothing about the house to attract the European Sparrows, no chickens were being fed and no grain was dropped about, so the Swallows were unmolested. They came year after year, and with them came many of the young of the year before. Anyone who chanced to approach the old house would see at all times birds circling about the chimneys, the gables and the tree tops, adding much to the picturesqueness of the sight:

This year the house has been occupied for a few months, but the family living there have not used the room where the Swallows have their nests, nor have they disturbed them in any way. The birds come in and out as before. They may well let them stay, for they have kept down the flies, while the Chimney Swifts have kept the mosquitoes in check, and the Wrens nesting in the crevices outside, the 


\section{BIRDSOF PEASEMARSH}

Flickers in the hollow trees, and all the other birds that have found a haven there, have done their share towards keeping the old garden and the orchard trees free from insects.

There is nothing remarkable about the condition of affairs at this old home. The birds have found safety and so they have come in greater numbers each year. Every country home might have the same bird guests and the same freedom from insect pests if the birds were protected from cats, squirrels and other enemies, man included, and permitted to have suitable nesting places. There are no more valuable tenants than the feathered workers, and none among them is more in need of hospitality and appreciation than the fork-tailed Barn Swallows. If we would keep them with us it is time to consider their needs while some still linger. 


\section{CHAPTER V}

THE BARN SWALLOW'S RELATIVES

DESIDES the Barn Swallow we have all his cousins, the Bank Swallow, the Tree Swallow, the Cliff Swallow, and the Purple Martin working late and early to keep down the flies, gnats and other winged insects that otherwise would make our summers unbearable. And, like the Barn Swallow, all the family are growing rarer as their old nesting places are taken from them.

Large numbers of Bank Swallows have been going farther from cultivated lands, an evidence that the formation of the river banks is changing and the high sand bank, where they would be unmolested, is disappearing. Nothing could be more interesting than to watch these birds in nesting season. Unlike the Barn and Tree Swallows, they nest in colonies. For their nests they have burrowed into the bank so cleverly that they seem safe from all bird enemies. Creatures that live along the streams, however, sometimes search them out, 


\section{B I R D OF PEASEMAR S H}

and there are instances where colonies of Bank Swallows have been destroyed by mink.

These birds soon learn to know those who are frequently about the sand bank, and will go in and out feeding their young without the slightest fear. But if they notice that they are being observed by a stranger, they will flutter about and alight upon almost every other crevice in the bank than that which leads to their nest. If the stranger sits down to watch they will invariably manage to dart in at a moment when his eyes are turned away, though this precaution is hardly necessary, for their nests are so deeply burrowed in the bank that it is not at all likely he could reach them. They have odd little safety devices too. Frequently they make several excavations connected by little tunnels, so that their exit and entrance need not be through the one leading directly to the nest, thus they can deceive a pursuer, or, if need be, escape from the nest.

Here on the Indian River, about half a mile from the Georgian Bay, where the sand banks have been left in their natural state, there are several colonies of Bank Swallows. One colony nests where the river flows through [ 38 ] 


\section{B I R D S OF PEASEM A R H}

what was once the site of an Indian village. Some of the oldest residents who can remember the bank as it appeared in those days, say it was high and sandy in places then as it is now; so it is likely that it has always been the home of the Swallows, and this is doubtless why swarms of black flies that have troubled other places have not existed here.

Sometimes in the early summer evenings the whole colony will join with the Swifts and Barn Swallows and fly about above the tree tops, here and there, in graceful curves and circles. It is a beautiful sight to watch hundreds of these birds circling above the house and barn and elms and aspens, especially when, as they come downwards or rise upwards, their wings catch gleams from the setting sun. Children will watch them for hours trying to distinguish, even at that distance, the fork-tails of the Barn Swallows and the blunt tails of the Swifts.

Another member of the Swallow family that, like the Barn Swallow, makes a nest of mud, is the Cliff Swallow. This bird in its natural state plasters its nest under cliffs, and hence the name. It, too, will come to the buildings 


\section{B I R D OF PEA S E A R S}

of man if unmolested, and plaster its nest on any protected niche of the wall outside. Usually it builds directly under the eaves of any old building where it appears likely to be undisturbed. Like the Barn Swallow it is a very desirable tenant, and as it is willing to come and live on our very buildings, we can have its services close at hand if we will but encourage it to come.

The little Tree Swallows have great difficulty now-a-days in finding a nesting place where they can have any degree of safety. They make their nests, which are woven of straws and grasses and lined with soft, downy feathers, in holes in trees or stumps, preferably in the vicinity of water. They are, however, much more easily helped than the Bank Swallows. It may not be possible to supply a sand bank, but it is always possible to put up nest boxes, and properly made ones will be gratefully accepted by Mr. and Mrs. Tree Swallow.

The Tree Swallows have decreased greatly in numbers since the old days of Indians and forests. Hollow trees, hollow stumps and decaying rails are very difficult to find and about barns and sheds are many enemies; and al- 


\section{B I R D OF PEA S M A R H}

ways there is the European Sparrow. Swallows seem less able or less inclined to hold their own than some other species of birds. If the gentle Tree Swallows are persecuted by the Sparrows when locating for the season they are very likely to leave and not return again. The men whose farms they leave are the losers. Instead of the useful family of Swallows they are left with an aggressive nuisance that may keep away other valuable small birds, as we shall read later.

The Purple Martin is the largest member of the Swallow family and a very beautiful bird. Like the Bank Swallows, the Martins nest only in colonies, but they build their nests in holes in trees or stumps. Unfortunately they have still greater difficulty than the Bank or Tree Swallows in finding a nesting place. A sand bank for a dozen or more, or a hollow tree that will accommodate one nest is hard enough for a feathered creature to find in cultivated lands, but hollow trees that would accommodate from twelve to twenty nests is almost out of the question. Thus the Martins have been forced farther and farther away. From many districts they have disappeared so long that houses 


\section{B I R D O F PEA S E A R S H}

put up for them remain unoccupied for years, not necessarily because the houses do not suit their requirements (though this is often enough the case), but because no Purple Martins have passed that way to see them.

The Swallow family is one of the most desirable feathered families. Not one among them takes a particle of vegetable matter, their entire food consisting of troublesome insects. A few pairs of Tree Swallows near the house, and some Barn Swallows in the stable, will help much to give comparative relief from flies and mosquitoes all summer long. That they are not more numerous is not surprising when their way is so full of difficulties. Like all birds that get their food from the insects of the air, often they are decreased in numbers during untimely storms which clear the air of insects. Though they have been known to resort to the ground to hunt when the insects are too chilled to fly, the flurries of snow which often accompany the storms make this impossible. One cannot cultivate the Barn Swallow and his relatives without a growing sympathy for these invaluable birds. 


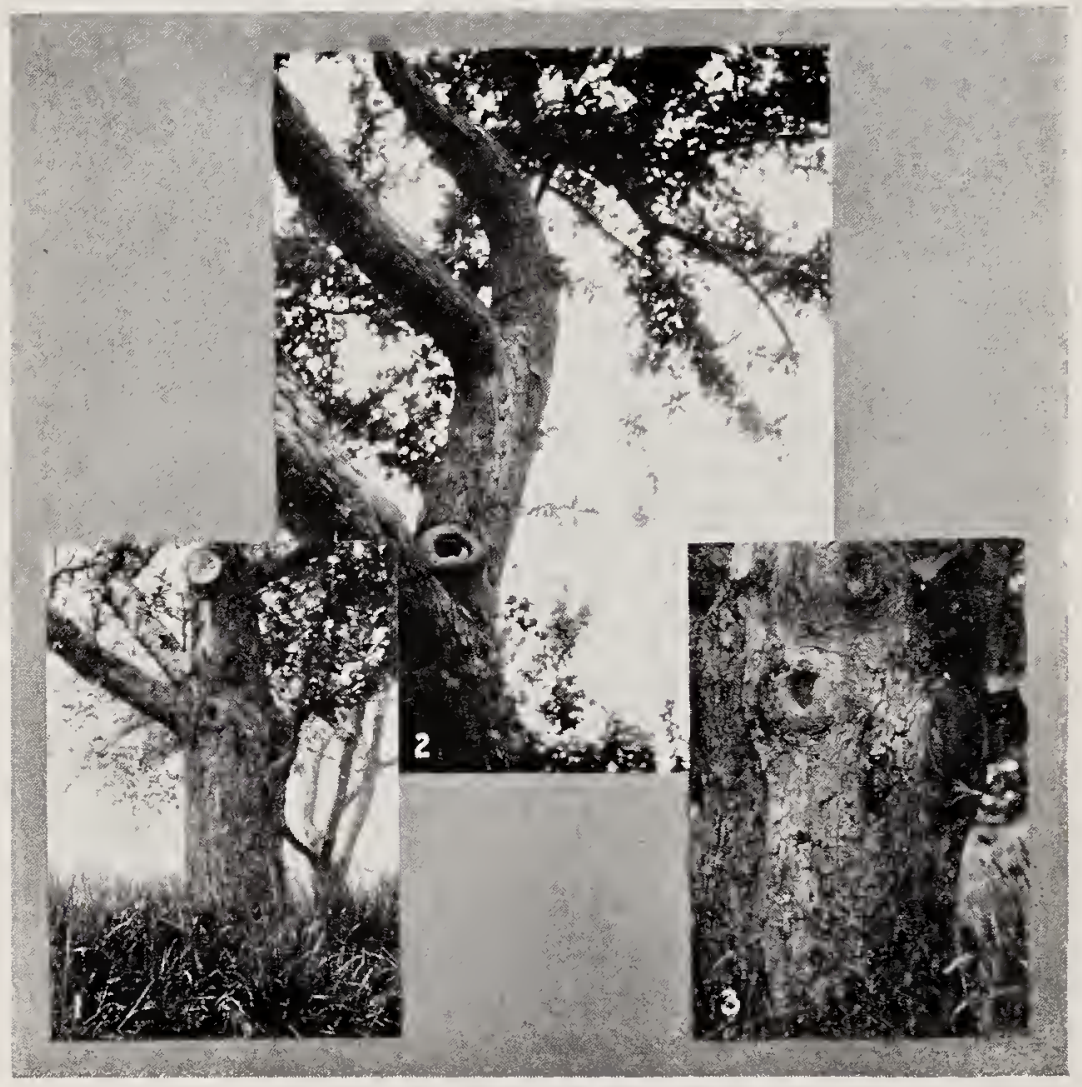

1. Flicker making an entrance (Page 40.)

2. A home which affords a better view

3. Young Flicker at entrance. (Page 41.) 


\section{CHAPTER VI}

BIRDS THAT NEST IN HOLLOW TREES AND STUMPS

T AST spring the Flickers were in the orchard early in April, before there was any appearance of spring foliage and when the fields were bleak and bare. Before the nest boxes were put up they had examined all the trees that gave the slightest evidence of a hollow centre. One of the main limbs of an apple tree had been cut off, and the portion where it had been cut was decaying in the centre; evidently the Flickers took it for a hollow tree and commenced boring a hole as round and smooth as any bit could have made it. When they had gone in a couple of inches and found no further evidence that the tree was hollow they gave it up and tried another, which turned out to be really hollow; and after making an opening they secured an excellent nest. Hard pushed for a home they must have been to work so long at the hard apple wood. This tree had been preserved for them after many arguments with the men, who said it was in 


\section{B I R D O F P E A E M A R S}

the way of the plough, that it gave the orchard a shiftless appearance, and that they could not see the sense of going round a tree that no longer bore fruit, and many other reasons why the tree should come out.

But it was saved for the birds in the end, and in it the Flickers spent a very busy time. The decayed wood they pecked from around the opening made a soft sawdusty lining, for the Flicker builds no nest inside his house, and here they hatched a family of five. Weary work it must have been to feed them all, and the old Flickers had no time to be disturbed when a camera appeared, but flitted in and out of the nest and were easily photographed.

Before very long the strongest of the family appeared at the opening of the nest, calling hoarsely for his mother to hurry with the dinner. One day when he was thus engaged a big Crow appeared, the Crow that only the day before had carried off a young Robin. The young Flicker ducked his head down and kept very still; all his brothers and sisters were quiet also; not a sound could be heard from the tree that a moment before had been a very bedlam of demanding voices. The old Flickers 


\section{BIRDS OF PEASEMARSH}

had been nowhere in sight when the Crow appeared, but instantly they were both on the spot. They were not to be taken unawares by a bird-nesting Crow. The Crow knew it, and soon went off to trouble them no more.

It was not long before the first young Flicker came over the edge and began to try his wings, and the one next strongest took his place at the opening, till he too was out. Judging by the fluttering about and the different tones one heard, this was an anxious time for the old birds. But in a remarkably short time all the young ones could follow them about for their food. As they grew older and were able to hunt for themselves, the old birds would disappear through the day and the young ones would have to get their dinners as best they could. But towards evening the family was reunited, and one might suppose from appearances that the young were giving an account of the day's work. Then they had supper together in the orchard, or on the corner of the lawn, where they had found an ant hill. One evening the smallest of the family went up to the mother and opened its mouth appealingly, but she would not feed it. Very quickly and very 


\section{B I R D OF PEASEMAR H}

forcibly she gave it to understand that it was now a grown up young Flicker and the days of following its mother about for food were gone forever.

Poor little Flickers that in a few short weeks must learn all the ways of the world of birds! Only a few weeks before they were babies, one family in the hollow tree, another in a nest box, and another in a crevice in an old stone wall. Now they must hunt their own meals, avoid bird dangers, and in this the old familiar advice "try, try again," does not apply at all; the first mistake means tragedy, and more than this, they must soon be ready to start on the long journey to the winter home. The birds find no one to give them a lift on the way. Their little wings must take them every mile they go.

Of all the Woodpecker family perhaps the Flicker, High-holder, or Golden-winged Woodpecker as it is sometimes called, has been inconvenienced most by the changing conditions of the country. Possibly this is because its food is somewhat different from that of the other Woodpeckers and it desires to nest nearer the cleared land, for the Flicker is really a ground [ 46] 


\section{BIR D S OF PEA S E A R H}

feeder and will devour great quantities of ants and grasshoppers and ground insects. But, poor Flicker! where he finds the hunting ground that he requires it is hard to find a decaying tree or a hollow stump in which to rear his family.

The most beautiful member of the Woodpecker family is the Redheaded Woodpecker. With his body all clear black and white, and his head a brilliant red, he is a very noticeable guest should he chance to visit the orchard in the early spring. He is unfortunately more shy and much more rare than the Flicker. As he works among the trees and nests in hollow trees or stumps, he has retired with the clearing of the land and the disappearance of any abundance of trees. His beauty has made him a mark for the gunner, but fortunately this danger is growing less as his value is better known. A suitable nest box would attract him and he would pay high rent by the work he would do among the orchard or shade trees.

Here, where they have hollow trees in the bush and swamp below the hill, they have never chosen to occupy a nest box, though they are often in the orchard and near the orchard. 


\section{BIRDS OF PEASEMAR S H}

Evidently they prefer their own natural sites when procurable.

A far-seeing bird lover has remarked that of all the Woodpecker family the Redhead is most in danger of being lost to the farms. When he states as evidence that in motoring for thirty miles through the country he saw only one (though Flicker and Downy were quite numerous), his note of warning rings true.

There is this about Redhead, if he once consents to keep house in a hollow tree or a nest box, he will come year after year, and so, carefully guarding his nesting place will help to keep him with us.

The Redhead and little Downy, the black and white Woodpecker with the red spot on the back of his head, and his cousin Hairy, that resembles him so closely, are among our most beneficial workers among the trees. Their sharp beaks can dig the grubs out of the wood or hammer away the loose bark to get the insects from underneath. Hairy and Downy also nest in holes in trees, as do the Nuthatch and the little Chickadee, but as these birds spend the winter with us we shall read of them 


\section{B I R D OF PEASEMARSH}

and of their good deeds among the trees in a chapter on resident birds.

There is another member of the Woodpecker family, however, whose usefulness is sometimes wrongly questioned. This is the Sapsucker, easily distinguished from the others by his scarlet throat. Mrs. Sapsucker, however, wears no scarlet at her throat. Sapsucker's name denotes the habit which has brought condemnation upon him, although authorities on birds declare that his sapsucking does not injure the trees, and that in other respects the bird is as beneficial as his relatives, Downy and Hairy and Redhead.

Long before man found out the use of sap this woodpecker would bore small holes in the bark in the spring when the sap was running. This is why he is so often seen motionless on a tree trunk. He is waiting for the sap which is running from the hole he has made. Some, however, believe that he does this more for the insects that the sap attracts than for the sap itself.

Here, near the house, is a maple where every spring the Sapsucker comes, and late and early may be seen on the tree where he has tapped it. 


\section{B I R D OF PEA S E A R S H}

Possibly something in the location of the tree attracts him. He is always seen on this particular one, though others are near by. This Sapsucker's tree is just as vigorous and its foliage as green and shady as that of the other maples.

In any case we know of no evidence that his sapsucking has ever killed a tree, and very often those who condemn him most are they who do not hesitate to tap their maples, taking from them much more than would flow from the holes the Woodpecker has made. It is just another instance of the Robin in the cherry tree. The Sapsucker has helped to save the trees, but the moment he helps himself to just a little of what the tree produces out comes man's gun. If the birds could think human thoughts and speak in human language what a story they would have to tell.

Sapsucker's nest is also in a hollow tree or stump, but unlike Downy and Hairy, he goes south for the winters with his cousin Redhead.

It is not always that an entire family of birds nest in the same way as does the Woodpecker family. Some families differ widely in their housekeeping requirements. The Crested 


\section{BIRDS OF PEASEMARSH}

Flycatcher is the only member of his family to nest in a hollow tree or stump. His cousins, Kingbird and Wood Peewee, build their nests usually on low trees, while his well known cousin, Phoebe, is sure to be found building on the rafter of some old building, or in a niche of some wall, or possibly under an old bridge. The Crested Flycatcher has not consented to live very near to us. It may be that he prefers to leave this hunting ground to his cousins, of whom there are many, or it may be that his tastes are better suited in the wood below the bank.

The boys who have the advantage of climbing trees and watching the bird world in the early morning from some high look-out point in the top of an elm or maple, say that a pair of Crested Flycatchers arrived at the orchard one morning in the spring and appeared much interested in a nest box on the sunny side of an elm, but before they decided to locate they quarrelled with their domineering cousins, the Kingbirds, already in possession of the bank, and departed straightway to the woods.

The nest box was afterwards appropriated by a pair of Wrens that had failed to find an [51 ] 


\section{BIRDS OF PEASEMARSH}

unoccupied wren house. The Wrens, appreciative of any attention, are increasing so rapidly where nest boxes are supplied, that one is not always ready to accommodate the number that arrive. Fortunately, of all the birds that nest in boxes, the Wrens are the easiest to please, and will accept almost any sort of a house. Though the Wrens are later comers than many birds, they claim the old nesting places with the most joyful outbursts of song. Probably it was the song of the Wren that gave origin to the stanza sung in Ireland by peasant lads the morning after Christmas, as they went from house to house carrying the branch of an evergreen tree on which was perched a little bird.

"The wren, the wren, the king of all birds. St. Stephen's day he was caught in the furze. Although he is small, his family is great. Get up, young ladies, and give us a treat."

An authority on birds, who recently visited the Blue Mountain district of the Georgian Bay, remarked that the Bluebirds were more numerous here than in many other parts. Had his visit been made some years ago he would have found more Bluebirds than we have now. 


\section{B I R D OF PEASEMARSH}

If they are more numerous in this district than in other parts they must have decreased universally, and it is quite time this was given serious consideration. Bluebird houses have been placed in many gardens by bird enthusiasts, but something more should be done on the farms for such useful and beautiful birds.

As the Bluebirds are naturally shy they will seek nesting places first in the country. But though we have vast stretches of farm land, a safe and suitable nesting place has not been so easy to find within the last few years, when clumps of trees and bits of swamp and bush have been disappearing so rapidly. Time was when there was scarcely a farm without a few acres of some sort of bush and swamp, and rotten cedar stumps or hollow trees could be found almost anywhere. Moreover there were rail fences then, a great boon to birds that nest in a hole, for they are sure to find a hollow rail somewhere, and the long grass or bushes in the fence corners made excellent cover for the young.

Now it is not only the bush and swamp that has gone, but picturesque rail fences are also 


\section{B I R D OF PEASEMAR S H}

disappearing and stiff wire ones are taking their places. True these have posts, but they are too new to have holes and sometimes they are painted, and newness and paint are foreign to the feathered tribe.

All this has forced the Bluebirds nearer the orchard and house, where they have to be satisfied with any sort of a home they can find. Seldom can they get one where they are safe from cats, and always they are in danger from red squirrels. Then, if the nest happens to be near the buildings, they will have the European Sparrows to torment them.

Nothing at Peasemarsh has given more pleasure-or profit-than the Bluebird houses. Nothing adds more to the beauty of the grounds than the bits of sky blue flitting here and there or resting on the gate posts. No birds are of more benefit to agriculture. Those that have nested here for several summers lose much of their shyness and let us know all the secrets of their housekeeping. It was some time before they became accustomed to the camera, however, and it was not until they had babies to feed and had to get back and forth from their house in spite of that new, silent terror beside 


\section{B I R D OF PEASEM A R H}

it, that a picture could be taken. Photographing them gave an excellent opportunity for observing their habits. Their house was on a huge elm just at the edge of the barnyard. Under it were a few big stones, and the old gateway through which sheep and cows and the pony and old horse passed to and from the pasture. To one side was the old pear orchard and a stretch of uncut grass leading to the apple orchard. Back and forth the Bluebirds flitted, sometimes down the old lane, sometimes through the orchard, and sometimes far back across the pasture to the spring and the bush at the foot of the hill. When taking their longest journeys they would be from fifteen to twenty minutes in returning. Occasionally they would meet and greet one another at the nest, at other times one would come and go again before the other returned. Once, when the camera grew alarmingly near, the mother bird was the first to come. She flew to a branch near by and looked at it from all directions. She was afraid to venture past it to the nest box opening. Holding firmly to the beetle in her beak she waited. The father bird came with a very long worm and they con- 


\section{BIRDS OF PEASEMARSH}

sulted together. Then, although it was the mother bird's turn, he flew nearer and nearer the nest box until, with one brave dash, he gained the opening and darted in. He fed his open-mouthed offspring, performed his housekeeping duty, cleaning the nest since his last visit, and returned to his timid mate, flapping his wings in triumph. As we watched he tried to take the beetle from her beak to carry it in for her, but she turned her head away, scorning his offer. No, she intended to do her own dangerous work. Trembling, she flitted nearer and nearer. The babies twittered, knowing that she was near, though she made no sound. Again she flitted nearer, till with one bold dash she entered. Her mate waited to see her safely out, though he was by this time due to be back with another worm. She came in a moment, flying straight to him for his approval. They embraced each other, and side by side they flew away for more insects, two bits of clearest blue, passing across the old barn yard lane to the field beyond.

A few days afterwards, Cecil, an almost constant companion when among the birds, came running in, exclaiming breathlessly, "The 


\section{B I R D OF PEA S M A R H}

Bluebirds are out, the Bluebirds are out, where is the camera?"

Seizing the camera we hurried out, round the old barn, to the Bluebird tree. There were the excited parent birds with their family of nestlings out of doors for the first time and trying their wings. No wonder they were excited. Now the young ones not only had to be fed, but kept out of the hundreds of dangers that beset their way. Moreover, all their education had to be given them, and a bird's education means not only advantages, but their very life. One little bird had flown down to the middle of the big stone under the tree, and here we photographed it as it stood looking with wondering eyes at the world about it. The day was cloudy and the little grey creature did not show up very well on the big grey stone. Bluebirds, like other bright plumaged birds, do not get their coloring until they are older and stronger and better able to avoid dangers. Possibly alighting on the stone, which it so perfectly matched, that it was hard to distinguish it, was the result of its first lesson.

After taking the photograph we wished the Bluebirds luck with their family and left them. 


\section{B I R D OF PEASEMARSH}

It was more than a casual wish, for if the family lived to grow up and come back another year it would mean much to the farm. The number of insects less we should have to contend with would run into millions and billions.

The Bluebird belongs to the Thrush family, but as the other members of the family do not nest in hollow trees they are mentioned in a later chapter. 


\section{CHAPTER VII}

THRUS HES, THRASHERS, WAXWINGS, KINGLETS, WARBLERS, VIREOS

$7 \mathrm{HE}$ birds that nest in holes in trees and can be accommodated with a nest box form a very small proportion of the feathered population. Some of the most valuable birds build their nests high in the tree tops, some on horizontal limbs, some on firm crotches, some very near the ground, others on the ground. Probably the Robins are the most adaptable, placing their nests on many different sorts of branch formations and on ledges at different heights from the ground. Last summer one pair nested high up in a willow tree by the barn, another in a maple, another in the hawthorn bush, and another pair on a ledge in the stone wall, while several pairs were in the orchard making their nests in the sheltered nooks formed where suckers had grown out from limbs that had been cut back in pruning. 


\section{B IR D O F PEASEMARSH}

Bird families that are closely related are said to belong to the same order. The Robin belongs to a family in a large order of birds in which there are many families. But the Thrush family, to which it belongs, is one of the most valuable. It is also one of the most musical, for the Thrushes, unlike their brother the Robin, are renowned for their wonderful voices. It was of a member of this family that the poet wrote, "I hope to hear before I go the field note of the Veery."

Besides the Veery, sometimes called Wilson's Thrush, we have the shy Wood Thrush, the Grey-cheeked Thrush, the Olive-backed Thrush and the Hermit Thrush. These all nest in trees or bushes near the ground, but the Hermit Thrush sometimes nests on the ground. Early in May the Thrushes arrive from the south, preferring to nest in secluded swampy woods, where their songs are heard all through the early part of the summer. By August the Wood Thrush and the Veery are silent, and without farewell they soon flit away to the south. In nesting season the Hermit Thrush has a very sweet call note, much like the first note of its song, and if you can come near them 


\section{B I R D S O F P E A S E M A R S H}

unobserved you may hear this sweet call to the mate on the nest. Some members of the Thrush family are rare here, and being so shy and retiring they are easily alarmed. As insect destroyers they are very valuable, their food consisting largely of caterpillars when small, and the grubs found on the ground or just under the earth. Unfortunately none of these Thrushes are at all numerous. They are going with the clearing away of the woods, their cool and quiet nesting places.

The remaining members of the family, the Robin and the Bluebird, are not so retiring. The Bluebird, the Thrush that nests in hollow trees, was mentioned in the chapter on birds that nest in that way. Of all the Thrush family the Robin is the best known, the old standby. Not easily alarmed and able to endure the cold of early spring, it never fails to come, with its bright breast and its cheery note, to our very door announcing the coming of spring. Though not a song bird, it is so cheerful and familiar that we do not miss the music. What would a summer be without the bright "red breasts" hopping about on the short grass of the lawn, stopping now and then to dig out a 


\section{B I R D O F PEA S M A R H}

luckless worm or calling "cheer up, cheer up, cheer up" from the leafy tree tops. Besides, it is one of our most useful birds, devouring great quantities of army worms, cut worms, wire worms and injurious bugs and beetles, and coming to our gardens and our orchards for them. The poor Robin, so often blamed for stealing cherries, has paid in advance and paid many times over for all he takes.

\section{MOCKING BIRD FAMILY}

This is a family closely related to the Thrushes and consisting of only three members, the Mocking Bird, the Brown Thrasher and the Catbird, all slender, long-tailed birds and beautiful singers. The Mocking Bird lives only in the south, the other two are with us every year. The Thrasher is sometimes called the Brown Thrush, although it does not belong to the Thrush family. This beautiful chestnut-brown, long-tailed bird with the spotted breast, is very familiar in our orchards and the tree clumps. Early in the morning and in the evening it sings its beautiful song in the tree tops somewhere near its nest, which is always carefully hidden on the ground or near 


\section{B I R D S O F P A S E M A R H}

the ground. Sometimes in the spring when the foliage is late in coming out it will resort to the ground and hop about in search of insects, a dot of rich, warm brown on the cold green.

Our earliest memory of the Catbird was one evening in June when the sweetest of bird songs was poured forth from a small evergreen at the corner of the verandah. We peeped out very carefully lest we should alarm the singer, and there was a satiny, slate-colored bird singing a song sweeter and more varied than that of its fine-voiced brother, the Thrasher. Finishing its song it flew away to the shrubbery, where was its nest, and we heard its cat-like meuw, the note which has given it its name. There are still many who have not listened for its singing and do not know it has any note besides its cat call. They have missed much, for it is one of the finest bird singers we have.

This year the Catbirds were our nearest neighbors. They arrived upon the lawn early in May and the barberry hedge seemed to take their fancy from the very first. They made no rash decisions, however, but inspected every available bush and tree with great care, and after each decision they returned to the hedge. 
B I R D OF PEASEM A R H

Their greatest difficulty seemed to be to decide in which particular part of the hedge to locate. They spent a whole afternoon flitting in and out of it. They examined it on the south side of the house and they examined it on the north side of the house. The north side, where the branches of an old apple tree hung protectingly over it, seemed to be their choice when evening came. In the cold, grey dawn of the early morning we knew for a certainty that they had decided to remain, for a song of exquisite sweetness came through the open window; it was the home song of the most accomplished musician of the sanctuary, and the memory of it will remain long after the nesting birds have gone.

Both the Thrasher and the Catbird live entirely on insects, especially caterpillars and beetles, during the early part of the season, and so are very valuable in the garden. When the elderberries ripen they feed on these, and bushes of elderberries will always attract them.

\section{WAXWINGS}

The Waxwing belongs to another family of this order of birds. There are two species, but [64] 


\section{B I R D O F P E A E M A R S}

the Cedar Waxwing, or cherry bird, is the only one to nest here. That it is a beautiful bird is about all that is usually said of the Cedar Waxwing, for though it destroys some insects, it is not considered so valuable as many other birds. As it has the habit of visiting gardens and orchards in small flocks when cherries and berries are ripe, one wonders if they have devoured insects enough to pay their board while in the orchards. It has a good trait, however, which is frequently overlooked. It is an expert fly catcher, sometimes seeming almost to turn somersaults in the air after them.

\section{KINGLETS}

To the same order but to a different family belong the little Kinglets, Ruby-crowned and Golden-crowned, and the little Grey-blue Gnatcatcher that seldom comes so far north. The Kinglets nest in low trees, but usually farther north, so they are only visitors here. In the early spring they make their way northward, stopping on the way to examine our orchards and woods in search of tiny insects and insect eggs. They are the means of preventing millions of these from developing and 


\section{B I R D OF PEASEM A R H}

injuring the trees. In the autumn we have another visit from them when on their way south. Though some of the Golden-crowns remain in sheltered evergreens in southern Ontario all winter, they have not done so here.

\section{WARBLERS}

Over twenty members of the large Warbler family have watched over our trees. Some of these make only fleeting visits, usually nesting in more southern parts of the Province. Some others, like the Kinglets, nest farther north and stop only while on their way back and forth from their summer home to their winter home. But fully a dozen different members of the family have nested with us. Of these the Green and Yellow is one of the most numerous.

Most of the Warblers nest in low bushes near the ground: Last summer the boys who live below the hill watched a nest of little Green and Yellow Warblers in a lilac bush that grew beside their gate. The fifth egg was the last to hatch and that baby was small and weak, and a few days after it died. The old birds pulled it out of the nest and let it drop down among the leaves on the ground at the root [66 ] 


\section{B I R D OF PEASEM A R H}

of the lilac. That was the bird's funeral. But four were left to be fed, with the result that the lilac and all the bushes and trees near by were free from the tiny insects that the Warblers live upon.

Another very common Warbler is the Black and White Warbler. Usually it nests on the ground at the foot of a decaying tree or stump. The Black-throated Green Warbler is also quite common and is frequently seen among our trees in the early spring. The American Redstart, known by the red orange on the centre part of the wings, is also here, and makes its nest on the crotch of a low tree. Last year they nested near the lake shore road; though we never found the nest we saw the Redstart roosting on the telephone wires almost every time we passed by in nesting season, and one bright morning the family of four little Redstarts were all there in a row.

The Oven Bird belongs to the Warbler family, taking its name because its nest is shaped something like an oven. Built on the ground, it is covered over and has an entrance at one side like the door of an oven. There is also a Mourning Warbler and a Pine Warbler 


\section{B I R D OF PEASEMAR S H}

that nests in the pine trees, usually farther south. Our own Canadian Warbler is one of the most beautiful, its favorite nesting place is on a bank among the roots of old trees or stumps.

The Warblers are most useful birds among the trees. As so many of the insects that they devour are small and undeveloped, they are not always given full credit for the good they do. They are a family that guard the trees from the ground to the very tip. Some search for insects among the fallen leaves; others examine the bark of the trunk and limbs for tiny insects that larger birds have missed; others go from branch to branch clearing the leaves of insects; others catch insects that are flying about the trees. One of the greatest values of these birds is their habit of devouring newly hatched caterpillars and of feeding the larvae of these caterpillars to their young. Since the caterpillars are the greatest leaf destroyers we have, and as trees cannot breathe without their leaves, the Warblers have a large share in saving them for us.

We have also watched these tiny birds gathering leaf eating beetles and bark beetles. 


\section{B I R D OF P E A E M A R H}

Of the bark beetles one ornithologist says: "These beetles' eggs are soon deposited and the resulting larvae bore away among the vital tissue of the tree along the inner surface of the bark. If their increase is not checked a year or two of their work is sufficient to destroy the noblest tree of the forest. The Warblers, however, attack these borers as they mature and emerge from their burrows. In an orchard they are invaluable. The Black and White Warbler, which is so often seen on the tree trunks in the summer, is the greatest destroyer of borers, though others also eat them."

\section{VIREOS}

Another family not unlike the Warblers are the Vireos. The family, however, is much smaller, consisting of only six members. Only three of these have ever been seen here, though the others may appear in other parts. Like the Warblers they work chiefly among the leaves and branches of the trees. They are constant singers and always hunting for food, for their appetites seem insatiable. We have frequently watched a Vireo in a willow tree by the house catch and devour a caterpillar without losing a 


\section{BIRDS OF PEASEMARSH}

note of its song. Their nests are shaped like little cups and fastened to a twig or the end of a forked branch in a low tree. The nest in the illustration was found in a pear tree by the boys who, when picking pears, were attracted to it by the narrow strips of birch bark so fantastically woven in it. Surely they are artists to have designed such a home. 


\section{CHAPTER VIII}

FLYCATCHER FAMILY, PRAIRIE HORNED LARK, SCARLET TANAGER

S early as the middle of March we hear
the familiar "Phoebé, phoebé," shrill,
loud and persistent, and we know that the first member of the Flycatcher family has arrived. The others follow in due course. The Wood Peewee, daintier and smaller than Phoebe, never fails to appear. Occasionally Least's Flycatcher, still smaller, consents to come. Usually we have the Crested Flycatcher at various places on the farm, but as they nest in hollow trees they were mentioned in the chapter on birds that nest in that way. There are always numerous pairs of Kingbirds.

Phoebe, however, is an old standby, and the only one of the family that comes to our buildings to nest. For many years one pair have lived just over the front door, building their nest in a notch of one of the stones in the wall under the verandah roof. Once in three or four 


\section{B I R D OF PEASEMARSH}

years they would pull the nest down and rebuild it, other years they would simply re-line it or add a little fresh moss to the outside.

Other pairs of Phoebes nest about the sheds, and down under the little railway bridge over the stream flowing from the bush a Phoebe's nest has been built ever since we can remember, the roar of the passing trains disturbing them not at all. The favorite look-out point of those that nest under the verandah is the telephone wire outside the window, from which they dart after every winged insect they see. Their peculiar manner of jerking the tail has given them the name "Wag Tail" among the children.

The Wood Peewee nests down on the orchard bank among the trees, and usually watches for its breakfast from the end of some dead limb. It is very like its cousin, Phoebe, but easily distinguished from it by its smaller size and the white bars on its wings, and also because it does not "wag" its tail. Its call, "Pee-a-wee, pee-a-wee," is slower and more musical than that of the Phoebe.

Least's Flycatcher, or Chebec, as it is sometimes called, is smaller than the Wood Peewee 
B I R D S O F P E A S M A R S H

and not so numerous here. It accompanies its singing, which sounds not unlike its own name, Chebec, with both a movement of the tail and the head. It has also white bars on the wings.

Our largest member of the family is the Kingbird, and fortunately a very common resident. The Kingbirds are easily distinguished by the white fringe at the end of the tail, but if this fails to identify them watch for a pair of dark-colored, light-breasted birds that dare to chase a bird-nesting Crow out of the orchard, frequently flying above him and giving him such jabs with their beaks that he is glad to squawk his promise to stay away henceforth.

Being good sized birds they build rather bulky nests ten feet or more from the ground in some bush or tree. They are adepts in defending themselves, and woe betide any Crow or Blackbird that comes too near. They are the guardians of the bank here, for by defending themselves they are protecting all smaller birds that nest anywhere near.

The value of the Flycatcher family is very great. As the name implies, they live principally on winged insects and do not touch cultivated fruit, though sometimes in the early 


\section{B I R D OF PEASEM A R H}

spring the Kingbird will be driven to eat the berries of the sumach.

\section{THE LARK}

We have but one member of the Lark family, the prairie Horned Lark. One day in March, driving along a country road we saw a group of them on the roadway just ahead. They were very easy to distinguish, for their two little horns are especially noticeable when they are pecking for food on the ground. Flocks are sometimes seen in February and March, doubtless on their way farther north, though they have been known to nest here. They make their nests on the ground in the open fields. Some of these birds are said to spend the entire winter in the southern part of Ontario and the northern part of the United States.

\section{THE SCARLET TANAGER}

If the Tanager family is a small one, its sole member known here is one of our most brilliant birds. The Scarlet Tanager is easily recognized by its beautiful scarlet plumage and contrasting wings and tail of black. In a 


\section{B I R D OF PEASEMAR H}

season when the foliage is late in coming out he is very noticeable among the dull branches. The Tanager's nest is built on a horizontal limb of a tree, usually in some secluded spot. Last spring a pair came almost to the door, apparently looking for nesting material, but we could not induce them to stay and nest there. Later we found that they had gone to the larger trees below the bank.

Beside the brilliant Tanager his mate looks very plain in her coloring of olive green and brown and greenish yellow. One of nature's means of protecting the nests of bright plumaged birds is to clothe the mother bird in quiet shades. If she were bright she would attract attention to the nest, but her coloring blends with the trees and the material of the nest. When bringing out her family she escapes notice, while the father bird, with his bright plumage, can draw attention away from the nest by simply flying in the other direction. 



\section{CHAPTER IX}

THE FAMILY OF FINCHES AND SPARROWS

WITH the exception of the Warbler family, that of Finches and Sparrows is one of the largest. Some of this family are our best known birds, coming in the early spring and remaining with us until the last migrating birds are going. Some only visit us in the spring and fall on their way back and forth from their nesting places farther north. Others spend their winters with us and make the Arctic regions their summer home. The birds of this family are both insect eating and seed eating. Though they devour the seeds of many noxious weeds they do not touch cultivated grain and are most useful on the farms. The only objectionable Sparrow we have is the European species.

Of our native Sparrows, the little Chipping Sparrow, noticeable among the others by its brownish mahogany head, is the most familiar. These little birds are always very tame, and, if there are not too many European Sparrows, 


\section{B I R D OF PEASEMARSH}

come hopping about the door for crumbs. Usually they make their nests in low trees and bushes, sometimes in the vines that grow about the porch. There is never a country home without a Chipping Sparrow's nest somewhere about. These trusting little birds come very close to us for protection, for they are so often unfortunate, their low nests being reached by cats or squirrels, or usurped by European Sparrows. Last year a pair here nested in the barberry hedge beside the stone wall, bringing out a very interesting family of four, and their first flight was from the nest to the table in the porch.

The Song Sparrow is a bird that would perhaps be more missed than any other should we have a spring without it. It is one of the earliest sweet singers, and its song seems more like sacred music than that of any other bird. Song Sparrows are always at Peasemarsh for Easter Sunday, and what sweeter Easter music than theirs could we have? Sometimes they arrive early in March and sing all through the cold, raw days while we wait the real coming of spring. Like "Chippie," they will come to the door for crumbs and grow very tame. One 


\section{B I R D OF PEASEMARSH}

late, cold spring when the foliage was much delayed, our little Song Sparrow would creep into the Barberry hedge for shelter at night. On one occasion a light suddenly appearing in the window near by it apparently took it for the sunrise and sang its little song, though about twelve o'clock on a cold, dark April night.

The poor Song Sparrow, nesting in tall grass or low shrubs, frequently comes to grief through prowling cats, or has its nest pulled to pieces by scythe or mower. A Song Sparrow here once made her nest in a little cluster of thistles, and it was noticed just in time to save it from the scythe. For the sake of the little nestlings the thistles were left uncut. But one thing is certain, the birds would not let all the seeds drop.

Closely resembling the Song Sparrow is the Vesper Sparrow, but always distinguished from it by its white outer tail feathers, which show plainly in flying. To some the songs of these birds may seem much the same, but those who listen carefully will find a great difference, which was aptly expressed by a young musician who said, "Their voices are something 


\section{B I R D O F P E A E M A R S H}

alike, but the Vesper Sparrow does not sing the music the Song Sparrow sings." The nest of the Vesper Sparrow one comes upon in most unexpected places on the ground. The Field Sparrows usually nest on the ground also, though sometimes they build in low bushes. The Grasshopper Sparrow is another very common little friend in our fields.

The Sparrows that nest farther north are always welcome guests. We cannot call them tenants, because they simply visit us as they pass between their summer and winter homes. We watch eagerly for the coming of the White Throated, the White Crowned and the Fox Sparrows. The White Throats and White Crowns are easily distinguished, as their names are descriptive, and so white are their crowns and their throats that there is no mistaking them. In some seasons they remain much longer than others. When they stay for several weeks we are likely to have a late, cold spring, this doubtless being the reason why they are in no hurry to pass on to their nesting places. Throwing out crumbs will bring them to the door, where they can be watched to great advantage. The Fox Sparrow, when with us, is [ 80 ] 


\section{B I R D OF PEA S E A R H}

always much shyer. But though he does not come so near, his voice reaches us. When on sunny April mornings he mounts to the tree tops and pours forth his glorious notes, he fills the air with music. Unfortunately his stay is frequently shorter than that of the other two.

Upon their return visit, about the middle of September, these Sparrows have their families with them and make quite an extended stay, hunting out our weed patches and devouring great quantities of seeds.

Usually they have gone their way by the time their cousins, the Tree Sparrows, come from the north to take a final look at our weed patches and glean what the others have left, for the Tree Sparrows come with the Snow Birds and tell us that winter is on the way. Their names did not come from their manner of nesting, for they nest on the ground or very near the ground, and their nesting places are many hundreds of miles north, in Labrador and near the Hudson's Bay.

\section{FINCHES}

Of all the Finches the Goldfinch, wild Canary some people call it, is the best known here. 


\section{B I R D OF PEA SEMAR S H}

With their clear, yellow coloring and black wings and tail they are very beautiful birds. High up in a fork of a branch of a maple tree just outside the window a pair made their cup shaped nest last year. The tall maples are their favorite nesting places. Only rarely are their nests found in low bushes, but frequently they nest in a tall apple hedge here, and, flying in and out against the dense green, they look like rare gold. They are among our most persistent seed eaters, and, when a pair alight on a tall thistle, so intent will they be on getting the seeds that one can come very close to them. They are late in beginning their housekeeping, flitting irresponsibly about when other birds are searching their nesting material, and only beginning to build when many birds have already nestlings to feed.

Curiously enough the Purple Finch is distinguished by its crimson color, very vivid on its head and breast. The wings and tail, however, are a dull, brownish shade. The mate is dull grey brown, her breast white but well streaked with brown. It would be very hard to find her while on her nest or guarding her little ones, so like the nest and the branches [ 82 ] 


\section{B IRDS OF PEASEMARSH}

does she appear. The nest is usually in a low evergreen or unpruned apple tree. One wonders if the Purple Finches were named after the eggs, which are spotted with a dull shade, frequently purplish.

One cold, bright May day we saw an Indigo Finch, or Indigo Bunting, the bird with the blue body and rusty black wings, perched upon the top rail of the fence surveying the thicket just inside the orchard which we had left for the birds. For some time he remained perched thus. The wildness of the spot and the many sprouts and low bushes must have looked good to him, for he flew over to it and disappeared among the opening foliage. Though we watched for him we did not see him again and feared he had thought unfavorably of our bird home. But a few weeks after we saw grey and brown Mrs. Blue Finch gathering small sticks and straws and flying with them to the thicket. Perhaps he had chosen a bush to nest in that day and gone in search of his wife. In any case they went to housekeeping there. Low bushes in sheltered spots are favorite homes with them, as they nest only one or two feet from the ground. 


\section{B I R D O F PEASEMARSH}

There will be less dandelions in the lawn and less thistles in the fence corners if the Finches are near by to devour the seeds.

It is interesting to notice how the habits of bright plumaged birds keep them where they are least conspicuous. The Indigo Bunting generally sings on the top of a bush or tree where his vivid blue coloring blends with the background of the sky.

Another of the Finches is the Pine Finch or Pine Siskin, a northern Finch that loves the pine woods. It is very fond of the seeds of birch, or pine, or spruce, and an abundance of these trees may attract it. Though it nests farther north it sometimes visits us in small flocks in the fall.

\section{SNOW BIRDS}

To this family also belong the Juncos and the Snow Buntings, Snow Birds or Snow Flakes they are sometimes called, because they have so much white that in flocks they look like huge snow flakes.

In the autumn the Juncos appear here in large flocks. One October morning they simply surrounded the house, perching every[ 84 ] 


\section{B I R D O F P E A S E M R S H}

where about, on the porch, on the window ledges, on the shutters, on the vines over the windows, their white beaks showing very white indeed against their taupe-grey, satiny feathers. They were returning, with their families, from their nesting places in the mountains or the spruce woods. The Juncos and the Snow Buntings visit the weed patches that rise above the snow of early winter. They come again in the spring and search out what they have missed in the autumn. True to their name the Snow Buntings nest within the Arctic circle, the land of snow and ice.

\section{REDPOLLS AND LONGSPURS}

One cold, bright day about the end of February sweet musical twittering brought us to the window, and there among the trees was a large flock of Redpolls, the first we had seen that winter, which had been uncommonly cold. They seemed quite tame, evidently having been attracted by the birch and cedar trees among which they were dining, the seeds in the catkins of the birch being a favorite food. Creeping quite close we examined the flock carefully through an opera glass. Some had very crim- 


\section{BIRDS OF PEASEMAR S H}

son crowns and beautiful red rose breasts. Some had only dull red crowns and no rose on the streaked breasts. Others had no rose at all and looked very like other little Sparrows. So we knew they were mother and father Redpolls and young Redpolls in all their distinguishing feathers.

The Redpoll is never a regular winter visitor, and it was some time since we had seen so large a flock. The visit, however, was but a fleeting one. The next day they were gone. Where had they come from and where were they going, those tiny, sweet-voiced travellers in that twenty below zero atmosphere?

The Longspur's home is in the far north. If he should call at the sanctuary it would be a surprise, for he has never led us to expect him. We are told that he is a very sweet singer when at his nesting place on the arctic coast. Nature gave rare music to those lonely places when she sent the Longspur to rear his family there.

\section{CROSSBILLS AND GROSBEAKS}

Two other members of the family are irregular winter visitors. So beautiful are they that we try to cater to their tastes by way of 


\section{B I R S OF PEASEMARSH}

food, hoping to induce them to come as regularly as the Snow Birds. These are the Crossbills and the Grosbeaks. The Rosebreasted Grosbeaks, however, will nest here if they find a suitable place. They are shy, retiring birds until they find that they are among friends who will protect them. With their black heads and throats, rich, dark red breasts and a little red on the wings and the other parts black and white, they make the most striking appearance of all the Grosbeaks. The real value of this bird, an appetite for potato beetles, should be better known. The Pine Grosbeak nests in the far north.

To look at the Crossbill's beak one would wonder how they manage to eat. But they manage very well indeed, that is what their cross bills are for. Cone-bearing evergreens, such as hemlocks, spruces and pines always attract them. With their cross bills they are very expert in gathering the seeds. Their nests are usually found in the cone-bearing trees.

The Red Crossbill is a rich vermilion red, but Mrs. Red Crossbill is grey, with a little greenish yellow on her breast. The White Winged Crossbill is more of a rose shade, but 


\section{B I R D O F P E A E M A R H}

with white wing bars, while his wife is grey, with some greenish yellow, and has also the white wing bars. The bright coloring of these birds looks very rich and warm against the snow and green of a late fall landscape.

It is most unfortunate that the spruce and pine groves are disappearing, thus lessening the visits of these attractively plumaged birds.

\section{TO WHITT TO WHEE}

We have seen that this family ranges from the plainest little sparrow to some of the most beautiful birds. There is one more member, a very handsome bird, To Whitt To Whee.

To Whitt To Whee comes early, sometimes arriving with the first little grey Sparrows. The first time we noticed him close to the house we heard something scratching like a hen among the dead leaves under the maple and supposed it was one of the hens, until we heard a hoarse To Whee and knew that To Whitt To Whee was there and that he had no cold, that hoarse To Whee or Chi Whee was just his natural voice. He kept on scratching and uttering his hoarse To Whee at intervals, as if he had no other means of expression, so al- 


\section{B I R D S OF P E A S M A R S H}

though we knew of his song, it was a surprise when he mounted a gate post and sang his sweet, strong notes. One day he was scratching and pecking so intently on the lawn that he paid no attention to us as we sat watching, and came within a few feet of us.

The children call him the bird with the white apron, and, indeed, with his glossy black head and throat and wings and rich chestnut sides, the white breast does look like an apron donned to protect his handsome dress. To Whee's wife is light brown where he is black, the other feathers the same as his, so she is not easily seen when on the nest, which is usually on the ground beside a stump or fallen log or brush heap.

One should not rake up the dead leaves too early if one wishes to attract To Whee, who likes to scratch among them for his dinner of insects. 



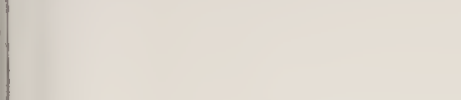
,

,

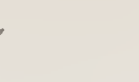




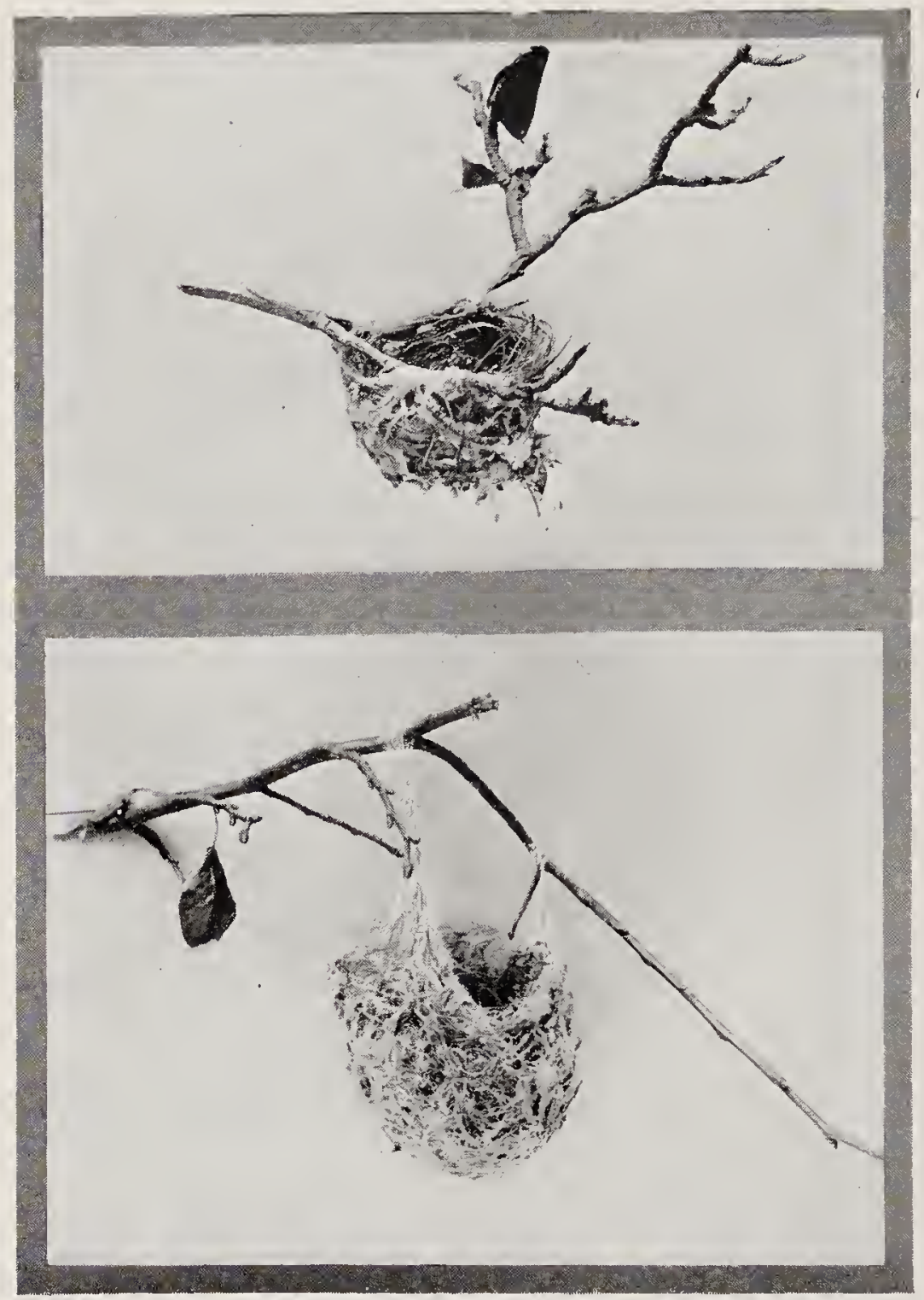

1. The weaving of the Oriole that has withstood the winter's storms.

( Page 92.)

2. The Vireo's nest: note loops of birch bark. (Page 67.) 


\section{CHAPTER X}

MEADOWBIRD, BOBOLINK, ORIOLE, BLACKBIRD, COWBIRD

70 another family belong our valuable Meadowlarks and Bobolinks that build their nests upon the ground, the brilliant Orioles that hang their nests from the branches in the tall elms, the Redwinged Blackbirds and their undesirable relatives, the Crow Blackbirds that do so much bird nesting, and the Cowbirds with their well known habit.

The Meadowlark is one of the early birds to arrive. From March until November it is working for the farmer. The number of insects that one pair alone will dispose of in that time would make serious ravages in the crops. Those who are advocating greater production should not forget the part of the Meadowlark. Some authorities on birds tell us that the young Meadowlarks are ready to leave the nest before the hay is cut, but this does not always happen, especially in the 


\section{B I R D OF PEASEM A R H}

alfalfa fields. Moreover some Meadowlarks are often behind the others in bringing out their families. This was the case on the farm last summer, when down in the meadow young Meadowlarks were big enough to fly about hunting their own food, but up in the clover field, which the men would be cutting any day, we had reason to believe was a Meadowlark's nest that would be in serious danger. Perhaps this pair of Meadowlarks had come to grief with their first nest and making a fresh start had delayed them until haying-time. So we attempted to locate the spot where their little ones were and protect it from rake and mower. To do this sounded easy, but Meadowlarks are very wise and wonderful. Were they not so they would have become extinct long ago.

Standing very still among the tall clover we saw the Meadowlark alight so near that we could hear the young when she went to feed them. Directly the bird flew up, we kept our eyes on the particular clump of tall grass from which she emerged and walked quickly to the spot. Not a sign of Meadowlark's nest! Had we mistaken the particular spot? Walking a little way off we watched again. But the 


\section{B I R D O F P E A S E A R S H}

Meadowlark dipped in at a moment our eyes were raised to look at a Bobolink singing near by. Again we were sure we heard the little ones and that the Meadowlark flew out from the same spot, and we examined every inch of the ground about there, but found no nest. And all the time the old birds circled anxiously about, confirming our belief that the nest was somewhere near. Our searching had aroused their suspicions and they tried to lead us away by dipping down at another place. The Meadowlarks in the lower field would not have minded our presence in the slightest, but this was evidently a pair that had not nested here before.

Presently, convinced that we had not found their little ones they went back where the hay had been cut, short grass being their best hunting ground. Partly hidden by the grass we sat down near the spot where we thought they had their nest, and waited. It was a long wait. The resourceful boy explained it by saying that worms might be getting scarce. .At last, however, the birds came flying over towards us with food in their beaks. One circled up to the rail fence and alighted on the highest post. 


\section{B I R D OF PEASEMARSH}

The other came nearer and alighted cautiously on the grass. The boy jumped up at once to see just where. Immediately the one on the post called to the other. It flew up, and together they went back to the short grass and they would not come again while we were there.

We searched again for the nest, while the small boy decided that it was not the difficulty in getting worms that had delayed them, but that they had been planning how to get to the nest without being seen, and their scheme was that one should fly to the nest while the other watched from the high post, and, if we were still there, call to it to come back.

Our search was in vain. So carefully was the nest concealed that surely it would be safe from the ravages of crows and blackbirds. Some days afterwards we found the spot low on the ground and domed over. The young birds had flown then. So one nest was safe, a thing which every year is becoming more unusual, for no bird is beset by greater dangers. Cats, red squirrels, crows and weasels all prey upon the Meadowlarks and, nesting in the meadows as they do, they would seldom rear [ 94 ] 


\section{BIR D O F PEA SEMAR S H}

their families had they not learned to conceal their nests so cleverly.

\section{BOBOLINK}

One cannot think of the Meadowlark without being reminded of his cousin, the Bobolink, for they live in the same alfalfa fields and roost on the same old fence rails and the same old barnyard gate-posts. We have seen a Meadowlark on one gate-post and a Bobolink on the other, each from that look-out point guarding his mate on the nest on the ground in the alfalfa. At this season Bobolink is dressed in his most beautiful plumage, his head, breast and wings look like jet-black satin and his back like richest brocade. No birds sing more sweetly to their mates on the nest than the Bobolinks. It is usually some time early in July before their young are ready to leave the nest, and, when nesting in alfalfa, the first crop of which is cut before that, their nests, like those of the Meadowlarks, often come to grief. By this time Bobolink ceases to sing and changes his beautiful plumage for a dress very like that of his plain brown mate. His real work has begun. He has a family to feed and 


\section{B I R D OF PEA SEMARSH}

to teach to avoid the dangers that beset them, and their perils are many, for all the enemies of the Meadowlarks are the Bobolinks' enemies too.

The young Bobolinks also encounter other dangers than those from the agricultural implements, prowling cats and bird-nesting Crows and skunks and weasels. In the ricegrowing states, when migrating, they are blamed for helping themselves freely to the crop and are often shot. Some ornithologists assert that the Blackbird does more harm than the Bobolink. If this be the case, it is to be hoped it may soon be thoroughly understood and so useful and beautiful a bird as the Bobolink spared to return to us.

\section{THE ORIOLE}

While Meadowlarks and Bobolinks nest on the ground their cousins, the Orioles, build their nests on the high-drooping branches of the tall elms. Wonderful architects they are to weave those hanging nests and fasten them so securely, from the four corners, to the branches that droop protectingly over them. 


\section{B I R D O F P E A E M A R H}

It is wonderful how these fragile looking structures withstand the winds and storms of winter and still retain their shape. Not far from the house are two elm trees just a few rods apart. In one is an Oriole nest of last year. In the other is a nest a pair of Orioles have just completed. So strongly made are those hanging structures, that, if there is any difference in the appearance of the old and the new, it would take the practised eye of the birds to detect it. What could reflect more credit upon the builders? We have never known the Orioles to occupy the same nest a second season, though they may build again in the same tree.

Only two kinds of Orioles are known here; one, the most brilliant, easily known by the black head and wings and red-orange breast of the male, is known as the Baltimore Oriole, sometimes called Fire Bird or Golden Robin, and is quite common; the other, not so brilliant a bird, but very beautiful when you have a close view, with rich greenish yellow and brown shades, is known as the Orchard Oriole, and is very rare in our orchards so far north. Early in May the Orioles announce their arrival by their whistling song, usually coming 
BIRDS OF PEASEMARSH

from the tops of the willows or the elms, or among the orchard trees. Much as we have wished to watch them weave their wonderful nests, we have never been able to do so. They choose a location so high and so sheltered by the branches that all we could see were the birds flying in with the material they had gathered. By the middle or latter part of June, when walking under the tree in which they have built, we can sometimes hear the call of the babies in the nest, which sounds like té-de-de, té-de-de.

If the Orioles were at all numerous in any orchard it would be comparatively free from caterpillars, and we should have no tent caterpillars in our gardens, and should never need to spray currant and gooseberry bushes. It is one of the birds that is important to the fruit grower. On one occasion a person with a small garden and one or two fruit trees bearing their first blossoms declared the Oriole a nuisance because it had picked some blossoms, and hastily concluded that the Oriole shou!d be shot, together with other birds that had wished to sample the blossoms. Such owners of small gardens might consider that out in the [ 98 ] 


\section{BIRDS OF PEASEMARSH}

country, where birds are more numerous than in any city garden, fruit trees blossom and fruit forms in such large clusters that everyone who wants a fine quality must thin them out; so the birds do not take very many blossoms. They have been spending most of their time getting insects and caterpillars. The Oriole especially has a tremendous appetite for tent caterpillars, often searching them out when they have escaped the spray. Moreover he is always watching, an advantage far above any spray device. The birds do not tell how many trees they have saved from destruction, and if on rare occasions they are seen helping themselves to a few buds, or a few cherries, it should be remembered that if everything they have done for the trees were recorded, it would be more than the human owners have done.

\section{BLACKBIRDS, COWBIRDS}

Of the Blackbird, cousin of the Bobolink, the Meadowlark and the Oriole, three kinds are found here; the large Blackbird, known as the Grackle or Crow Blackbird, the smaller Blackbird, sometimes called Rusty Grackle, and the Redwinged Blackbird. The Crow 


\section{B I R D OF PEASEMAR S H}

Blackbird is one of the worst nest robbers we have, and so we shall read of him in the chapter on bird enemies. The smaller Blackbird nests farther north, and is only a visitor here. The Redwinged Blackbird is not a nest robber, but in some ways a beneficial bird. Of late it has not been so numerous as one might wish, probably because the marshes where it likes to nest are being cleared and drained. It is one of the earliest arrivals, and also has the distinction of being one of the most dramatic of the feathered folk. All through the early part of the season it sings in strong, liquid notes, accompanied by twists and turns and graceful bows.

The Cowbird, another member of this family, is most undesirable, as it builds no nest, but lays its eggs in the nest of another bird, usually one smaller than itself, and pays no more attention to it. The small owners of the nest are forced to feed the young Cowbirds, which usually manage to get all the food and crowd out the little birds. The Cowbird is also mentioned in the chapter on bird enemies. Thus we see invaluable Meadowlarks and Bobolinks and Orioles have some relatives of very uncertain character. 


\section{CHAPTER XI}

GOATSUCKERS, SWIFTS, HUMMINGBIRDS, CUCKOOS, PIGEONS

$7 \mathrm{HE}$ order of birds to which belong the families, Goatsuckers, Hummingbirds and Swifts, is one of the most interesting and most curious that we have in the Great Lake region. Members of each family of the order arrive here every spring, and all summer we have an excellent opportunity to observe their habits. It is evening before we hear the -Vhip-poor-will in the bush below the bank, for while the other birds sleep the Goatsuckers are on duty, so its work is just commencing. This bird of the night devours the night flying moths and beetles, lessens the number of June bugs, and sometimes on still gloomy days, has been known to feed upon ants on the ground. It is a bird of the woodland and the woodland streams, though frequently it ventures out along the edges of the farm land, and sometimes at night it can be heard among the trees beside the house. The Whip-poor-will lays its 


\section{B I R D OF PEASEMAR S H}

eggs upon the ground among the ferns or the dead leaves in cool and shady retreats. The disappearing of the woodlands is making it a very rare bird in many places. One wonders if still more extensive cultivation will not soon drive it altogether from some localities.

The Whip-poor-will's cousin, the Night. Hawk, is not so retiring, and may be heard anywhere in country or in town when evening draws near. It is specially attracted by streams and rivers. Whether the peculiar sound of its downward glide is made with the wings or with the mouth has long been a matter of conjecture. The huge mouth and tiny beak by which this bird is always known are given it for its work of gathering in the night flying insects of the air. The eggs are deposited on the ground, but it does not hide them so carefully as the Whip-poor-will, for sometimes they have been found in the pasture fields.

Why should the Night Hawk and the Whippoor-will be called Goatsuckers? the children often ask. One boy answered it by explaining that it was because their big mouths suck in the flies that trouble the goats and sheep and cattle in the fields. 
B I R D OF PEASEMARSH

The Swifts are enough like the Goatsuckers to pass for cousins any day. But we have already read of them and their homes in our chimneys. The Hummingbird, however, is a very tiny relative of the Goatsucker, though it has the same distinctive characteristic of being constantly on the wing. Its diminutive nest is plastered on the horizontal branch of a tree, and is so grey and brown and green that one may look straight at it without seeing it. Little Rubythroat is always with us in apple blossom time. We hope to give him a little more attention, arranging to have a succession of bloom at his disposal so that he will always be a summer tenant.

\section{CUCKOOS}

The Cuckoos are birds whose good deeds, opening leaves and buds bring to mind. These slender, long-tailed birds clear the trees of a vast number of caterpillars. We have no other bird in the orchard that will devour the hairy caterpillar when full grown.

Two Cuckoos come to the orchard every spring, the yellow-billed and black-billed; apart from this difference they are very much 


\section{B I R D OF PEA SEMAR S H}

alike. They can be distinguished, however, by their note, the coo-coo call of the yellow-billed being lower and sweeter and softer than that of the black-billed. Both are slender, long-tailed birds with the upper parts brown, a slight olive tinge on the back and the lower parts white. They are fond of old orchards, especially unpruned orchards, and tangled thickets and overgrown fences. As they usually nest in low trees it is quite easy to avoid their birdlings when spraying the orchards.

There is only one other member of the Cuckoo order, and that is one of very little importance to the farmer, the Kingfisher. $\mathrm{He}$ is not much like the Cuckoo, but then when birds belong to the same order but not to the same family they should be called second cousins, and that is a sufficiently distant relationship to warrant distinct differences. We seldom see him anywhere, except down by the stream. Poor Kingfisher, his rent is always overdue, for he spends all his time fishing and pays no attention whatever to our injurious insects. Still, he is a handsome, cheery tenant, and we should not want our sanctuary to be without him. There is this to be said in his 


\section{B I R D O F PEA S M A R H}

favor, he attends strictly to his own affairs and troubles no one. Moreover, his loud note, like a very big rattle, is a welcome sound when in early spring it comes over the fields while the winds are still blowing off the ice.

\section{PIGEONS}

To another order belong the Pigeons. The Mourning Dove is all we have now. Years ago the beautiful Passenger Pigeon came and went in great flocks. That day is passed. The Passenger Pigeon is no more, and very rare is his shy cousin the Mourning Dove. It may be that Mourning Doves are decreasing in numbers because they cannot find the proper nesting places, although they have never been very particular where they lay their two white eggs. Nests have been found in old grape vines, on old stumps, on the top rails of old fences, or in low trees. So exposed have these locations been that their eggs have been known to have been blown off by the wind or the swaying of the branches, and for the same reason their babies sometimes come to grief. Such careless homemakers and parents of such small families are not likely to increase their numbers rapidly, 


\section{B I R D OF PEASEM A R S}

and the fact that they nest several times a season is the only thing that saves them.

Even though they have so wide a choice in nesting sites it is often impossible to find a safe location. For several years they had nested here about an old, overgrown, moss-covered shed. One spring a very tidy member of the family declared that the overgrown rubbish of locust sprouts, wild plums, honeysuckle and sumacs should be cleared away, the shed repaired and Norway spruce planted where the sprouts had grown. So this was done, but alas, for our Mourning Doves! When they returned, the over-grown shed was no more and we have never since been able to find their nest.

The Mourning Dove is interesting here because it is now the only Wild Pigeon. It is useful because of its economic value, living as it does exclusively on seeds, and a large proportion of its food being the seeds of our most injurious weeds. It is a beautiful bird and one which every sanctuary should attract and protect. 


\section{CHAPTER XII}

\section{RESIDENT BIRDS}

WHEN winter comes and the migrating birds are far away in the South, we still have our good friends the resident birds, that stay with us through the cold and storm of a northern winter.

Walking under a willow tree one December morning a piece of bark fell across our path, and looking up we saw the little Nuthatch, with its long beak and keen bright eyes. It flitted to another branch and hammered away a bit of loose bark, breaking it away in search of insects. Not far away the Chickadees were busy flitting up and down the tree trunks. Bye and bye the Woodpecker came in sight. So there were Nuthatch, Chickadee and Woodpecker doing the very thing that we would pay a man three dollars a day for doing much less thoroughly.

Later, there came a day of sleet and rain, followed by frost, which covered the tree trunks and branches with ice. What would the little 


\section{B I R D OF PEASEMARSH}

black and white Woodpecker, the long-beaked Nuthatch and the short-beaked Chickadee do now? The wind blew as it sometimes blows on the Georgian Bay. If forced to go to the woods they might not come back to the orchard. In a sheltered nook behind the hedge we hung a piece of suet. The first to come was the Woodpecker. His little feathers blew back and forth as he bored out his dinner. Then came the Nuthatch. The suet was freezing hard now and he had to hammer away before he could get a bite. He was rewarded at last, for he broke off such a big piece that he flew away with it to some spot where he could do proper justice to it. The Chickadees came next and pecked and pounded. They seemed to be satisfied with smaller pieces. Sometimes they made a good meal out of the crumbs the other birds dropped.

The suet was moved gradually nearer and nearer the house, until it was just outside the window. Although it was kept there always it did not stop the work the birds were doing. They were among the trees whenever possible. But the fact that when hungry a bit of food was always waiting for them kept them in the orchard. And so all winter long they worked 


\section{B I R D S. O F P E A S E M A R S H}

for us. Besides their work we had the pleasure of their visits at the window, and a delightful break it made in the dreary winter days.

Later in the season a Blue Jay came. The other birds always flitted away when he flew into the hedge or drew near the suet. Doubtless with good reason they had no love for him. But his feathers were beautiful. On a grey day he was a soft grey blue, and when the sun shone upon the snow he was the beautiful color of the sky, with flecks of white like the fleecy clouds. When perched upon a limb with the sky for a background he was so like it that one looked twice to see him. Even the dark bar about his neck was like the branches of the trees against the sky.

In spite of his beautiful feathers he has not a prepossessing face, and one can easily believe all the stories of his sins. His powerful beak and the big pieces of frozen suet he can break off, all go to show what tragedy he might bring to the nests of our most desirable birds. $\mathrm{He}$ devours some insects, but does he do enough good to offset his sins? Still, he is a cheery winter visitor, and perhaps it is too soon to condemn him. 


\section{BIRDS OF PEASEMARSH}

By the latter part of March these resident birds in most places are seldom seen. They have gone off to search out hollow trees where they can nest. Suitable nest boxes would keep them with us and increase their numbers. But Woodpecker and Chickadee nest very early, so their nest boxes should be up the fall before. A piece of suet hung near a nest box will attract them to it. It is possible that the birds may use these boxes to sleep in during the winter as they do the hollow trees, and in that case they are almost certain to remain and nest. Chickadees usually prefer a hole in a soft birch stub, so a house made for them of a decaying birch log is one most likely to find favor.

In the early spring the Red-breasted Nuthatch never fails to come to the orchard trees. At this season it is a very bright little bird, its reddish brown under parts giving a touch of warm coloring to the leafless branches. Late in the summer, when the leaves are out and we do not need its brightness so much, its red colouring fades and it becomes more like its White-breasted cousin. But though it has the same short tail and the same long beak, it is so much smaller that it 


\section{B I R D S O F P E A S E M A R S H}

can always be distinguished. There is no mistaking the Nuthatches. No birds have the same long slender beaks, and no birds do just the same sort of work on the tree trunks and large branches, caring not at all whether they go head downwards or head upwards so long as they can secure the insects they are in search of. The Nuthatch family, consisting of these two members, is a very valuable one.

When the Chickadees accompany the Nuthatches we may know that the work in the orchard will be very thoroughly done. Their strong beaks dig out the insects that would do much injury. But if by chance they should miss any insects, or if some borers should be so deeply imbedded in the bark that their beaks prove not the right tools for digging them out, there are two Woodpeckers that winter with us, Hairy and Downy; and Downy, at least, may be along any day.

If one watches the Woodpeckers at work one will notice that they have a different action from other birds in tapping on the trees. It is usually Downy we see, for the Hairy Woodpecker, the larger of the two, prefers the woods, 
B I R D OF PEA S M A R H

and does not come so often to cultivated orchards. But if Downy is given fair play he will be there with the Chickadees and the Nuthatches, and any fruit grower who does not realize what an expert he is in extracting borers and the larvae of the coddling moth should watch him at work. His beak can tear open the hardest cocoon the caterpillar can weave. Downy likes to keep his head up, and if he comes down a tree trunk he does so tail first.

Like the Chickadee and the Nuthatch, the Downy Woodpecker can be attracted to a nest box by suet, but a nest box that he will accept should be like his natural home in the woods. The most satisfactory are made out of sections of a decaying $\log$, the excavation flask shaped, and an inch or so of sawdust in the bottom to take the place of the peckings that drop when he hollows out his own nest in a tree.

There is still another helper in the orchard, little Tree Creeper. Its whole existence is derived from the trunks and branches of the trees. Its nesting place is the crevice under a flake of bark. Though a resident bird in the north, it is seldom seen here until late winter or early spring. It has several distinct little 


\section{B I R D S OF P E A E M A R S}

ways of its own. In ascending a tree its tiny body is very close to the trunk and partly supported by its tail, hence its name, Tree Creeper. It hunts only when ascending. When as high as it prefers to go it will flit to the ground and start up again, either on the opposite side of the same tree, or another tree.

These hard-working birds that stay with us through the frost and snow and storm of the long winter should have all the protection that human beings can give them. 




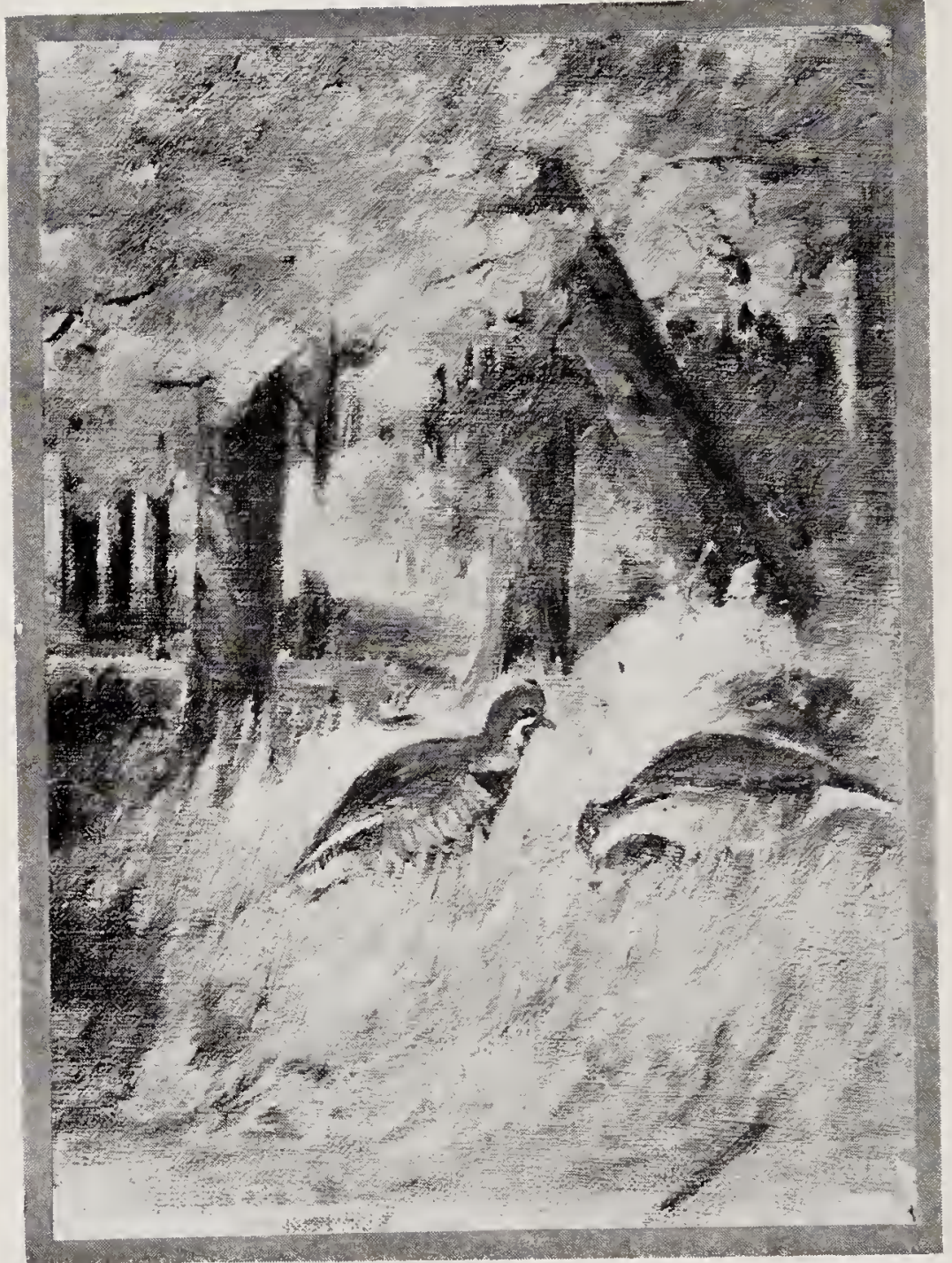

The Home of the Grouse. (Page 112.) 


\section{CHAPTER XIII}

\section{RESIDENT GAME BIRDS}

T ${ }^{\mathrm{HY}}$ have we so many potato bugs? The answer in a Quail district is very simple, we have shot little Bob-White.

Poor Bob-White, the best potato bug destroyer in the country, has gone the way of all the finest game birds. Outside of carefully guarded sanctuaries where are these birds to be found? Only in very secluded spots, and even there they have not been safe from the gunner for any length of time. Now that they have been given greater protection it is to be hoped that they will increase throughout their range.

The birds of this species which the gunner missed in his autumn "sports" were usually decreased in numbers by the snow in mid-winter, for, since they do not migrate and the humans for whom they worked for eight months of the year usually forgot them for the remaining four months when deep snow covered the ground, they were often unable to get food. 


\section{B IRDS OF PEASEMARSH}

They can withstand the cold if they have enough to eat, but without food they either succumb or are too weak to escape from such enemies as the Great Grey Owl, which make serious ravages upon them.

Where Quail exist they can be protected and the flocks saved by building a simple shelter and keeping it supplied with food. Waste grain would answer the purpose. But even this may not enable them to increase. Any that are spared to nest in the spring are at the mercy of the cat, poor Bob-White's most serious enemy apart from the gunner. In his home on the ground his ten or fifteen eggs, or nestlings, are protected only by an arch of grass, and where the cat finds them not one of the birdlings will be left alive; and each of these was soon to become a destroyer of our most injurious insects.

Considering all the dangers that beset the way of this little friend one cannot wonder that it has disappeared from many parts that were once considered Quail districts.

As it is a resident bird and a home bird, seldom going any great distance, the sanctuary can do very much towards increasing its num- 
B I R D OF PEASEMARSH

bers. Though we are so far north, we hope to try entertaining some Bob-White for a year, to see if with plenty of food and shelter they would thrive here. If a time should come when in every potato patch we should hear their whistling, Bob-White oh Bob-White, it would indeed be a happy day for the farmer.

When Bob-White eats weed seeds all winter he has a great appetite for meat in the spring. It is then that insects are at hand. Here are a few facts that have been gathered by investigators: "Everywhere Quail is an eater of weed seeds and insect pests." "In two states it has been estimated that Quail eat 1,341 tons of weed seeds in every year." One farmer reported his fields full of Quail and no damage from weevils. Another report stated that one hundred potato bugs were found in the crop of a Quail, and still another farmer reported that Quail were walking between his rows of potatoes picking the bugs off perfectly clean as they went.

PARTRIDGE

"What queer little brown hens out by the barberry hedge," said our guest one October [117 ] 


\section{B I R D OF PEA S E M A S H}

morning. We had heard a shot down in the bush, for this was before our sanctuary notices were posted, and we knew that "little brown hen" was a little hunted Grouse, or Partridge, that had been driven to our very door for protection.

We hurried out across the orchard, down the bank and round the edge of the bush. As we passed the grove of cedars there was a loud whirring of wings and a group of Partridge taking cover there, startled by our approach, flew off. Round by the lake we traced the gunner and saw him start towards town. Fortunately he had not shot anything, but he had alarmed the birds. It had always been hard to protect them, and although the bush and swamp with the uplands and the wooded bank where the white birch grew, was an ideal spot for them, they had been growing very few.

It is little wonder that the hunted game birds have all sorts of devices to save their young. None is more appealing than that of the mother Partridge when she tries to attract attention to herself by pretending that she has a broken wing. A very pathetic figure she makes, sometimes keeping only a few yards ahead of a pur- 
B I R D S OF PEA S E M A R H

suer. If he could disappear for a little while he would soon hear her clucking to her babies to bring them out from the dried leaves and ferns where they had hidden. It has been said of young Partridge and young Quail, that they can disappear from your sight while you are looking at them, without your having the slightest idea where they have gone. They seem to know just where they can dip down among the vegetation and match it so perfectly that they cannot be distinguished.

Like the Quail they are home birds. In winter when the snow is deep they burrow down and find shelter under it, where they spend the nights. They are sometimes caught by foxes as they leave this snowy shelter, for these sly animals will follow any track that they make when going in and out. And often in the late, dusky afternoon, when returning to these shelters, they fall a prey to the Great Grey Owl or the Horned Owl.

At times when the snow is very deep it is difficult for them to get food. Sheaves of wheat or oats tied to the tree trunks, ears down, and just above the snow, is one way of supplying them with food. 


\section{B I R D S O F PEA S E M R S H}

Their value as game birds is not their only use. Like Quail, they are valuable weed seed and insect destroyers. They are specially fond of grasshoppers, and late in the summer are often seen on the grassy uplands that edge the woods searching for these insects. 


\section{CHAPTER XIV}

BIRDS OF THE SHORE AND THE MARSH

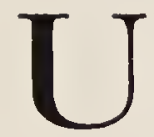

TP the Indian River, nestling in one of its small, deep curves, was a hay field that was the scene of a sad tragedy. Where the field bordered on the river bank the ground was soft and moist and the grass grew tall and rank. Here, unknown to anyone, the Bittern had made her nest of sticks and coarse grasses. Like all birds, she had chosen a nesting place where she was not easily distinguished. The Bitterns, pointing their beaks upwards among coarse, rank stocks, look like structures of the vegetation, and so, although often their note, which sounds so like the stroke of a mallet on a stake that it gives them the name of stake driver, had been heard, no one knew just where they were nesting. Excellent timothy grew in some parts of the field and, as that year hay was scarce, the mower was run over even that coarse grass near the river, and in its route along the bank it came upon the nest of baby Bitterns and two were killed. 
The driver regretted the accident chiefly because he feared the Bitterns would not return to nest there another year. True birds of the marsh, cousins of the Herons and the Storks, they are solitary creatures, and make their nests where they are not likely to be disturbed. In the spring when the wild flags are beginning to show green they come from the south and search out their nesting places. In every sense they are home birds, seldom wandering far from the spot they have chosen so long as they can get their food, which consists mostly of fish, frogs and lizards. When they nest near by one hears all through the early summer that thumping sound which gives them the name of Stake Driver or Thunder Pumper.

The agricultural implements are the least of their dangers, for usually they nest on land too rough and swampy for cultivation, or where the farmer would get poor returns for his labor were he to attempt to drive his mowing machine over the ground. The Bittern has been more in danger from the gunner and his dog than smaller birds of swamp and shore. Now that the beautiful Herons are gone from most of their old haunts, such birds as the Bitterns 


\section{B I R D S O F PEA SEM A R S H}

become the victims of the gunner. They have smaller cousins, known as the Dwarf Bitterns, numerous in some places. But the American Bittern needs greater appreciation and protection, especially now when the motor cars and motor boats take the irresponsible sight-seer among their solitary homes.

The Heron is one of the most beautiful and perhaps one of the most unfortunate of our large birds. Because it is tall and stately and rare, and found only in lonely places, it has been a mark for tourists who want some socalled trophy of their visit to the country. Years ago Herons nested here in colonies, but now are seen only in pairs. Great Blue Herons are frequently observed on the mill pond of the Beaver, the shrubs and rushes of the islands of the pond giving them the desired cover.

Another bird of the Marsh, though a member of a different family, that has often fallen a victim to the sight-seer is the handsome Crane. At a summer resort on the Georgian Bay only a year ago, when some children were telling of what their fathers had seen and done, one little ten-year-old said with triumph, "Father saw a Crane; he shot at it and almost got it." 
B I R D OF PEASEMARS H

Had her father got that Crane it would doubtless have figured as a stuffed bird in his library and its little nestlings would have been left to starve. It is the fate that has befallen many of these birds. Their size and their habit of standing motionless in the water watching for fish make them an easy mark for the tourist. And their haunts are in country places where laws for their protection have not always been enforced. They are not fishers only; Cranes, Storks, Herons and Bitterns are all destroyers of insects.

Where Cranes have been protected they become very trusting. Just at the mouth of the Indian River on our lake shore front, an artist was sketching one bright, late afternoon when the sound of wings drew her attention and directly a shadow crossed her canvas and a Crane lit in the shallow water in front of her, only a few yards away from the boys bathing in the river. The boys continued to splash about, shouting to one another to "Look at the Crane." The Crane, quite undisturbed, stood motionless watching for a fish, and the artist had time to sketch it into the picture before a splash (the movements were too rapid to be 


\section{B I R D OF PEASEMAR H}

distinguished) told that the fish had been caught and away the great bird flew to the nestlings beside the stream in the swamp.

The stately Crane added much to the picturesqueness of the landscape. It was the touch of life which nature had given to complete the picture. How beautiful such spots must have been years ago before its beautiful, unfortunate cousin, the White or Whooping Crane, had been slaughtered for its feathers, and when it, too, stood in the shallow water watching for fish for its babies, and adding its wonderful beauty to nature's picture.

It is to be hoped that before all our beautiful birds are gone we shall realize that they are treasures in our keeping and that for our care of them we are responsible to those who come after us. Had the plume-hunter, the feather dealer, the woman who wore the feathers, and the gunner who wanted to shoot every beautiful feathered creature he saw realized this in the past, there would be some White Cranes fishing in our streams to-day.

The Coot is a bird so often mentioned by the poets that the name never fails to call up some picturesque spot by stream or lake. "I 


\section{B I R D OF PEASEMARSH}

come from the haunts of the Coot and Hern," and many another verse have been familiar since our childhood. Belonging to the same order as the Crane, the Coot has the peculiarity of sometimes building a "floating nest," that is, it will make its nest on some clump of coarse grass or stalks growing just over the water and swayed by the movements of the water. On one occasion the grass on which was the nest was cut away in getting out some logs, and though it floated across the pond the bird went back to it and the young were hatched in safety.

Like the Coot and the Crane and the Bittern, the Loon is becoming more rare in settled parts. Though it belongs to a different order (the diving birds), its home is in lonely places by the water side, and as these haunts become invaded by tourists the Loons must go. But another reason for their disappearance is the clearing away of bushes and trees from the water's edge, making it no longer a nesting place for the Loon, which likes to nest where it is hidden by overhanging foliage.

To another order belong the Gulls and Terns, but they, too, are shore birds of won- 


\section{B I R D O F P E A E M A R S}

derful intelligence, if one could call it that. Across on the north shore a boy found two young Gulls whose parents had evidently come to grief. He carried them home, and every night when he came in from work he took them down to a small stream and caught tiny fish for them. Soon they learned to watch for him, sometimes going long distances to meet him. And when he took his fishing pole and started down the path to the stream they waddled along behind. Beside the stream they sat, one on each side of him and, as he fished, he gave a fish first to one and then to the other until their supper was over. Then they would waddle back to the house with him and go to bed each in its own corner. They grew rapidly and when the summer had passed they were full grown Gulls. As they had had no parents to teach them and had not mingled with other gulls, the boy wondered whether they would fly south. But one day they disappeared, and that night they did not come for supper. They had gone on the long, long fly. And the boy wondered how they would find their way and if they would ever come back to him again. But the charms of the south did not make them 


\section{B I R D OF PEA S E A R H}

forget their home in the north. Early one spring morning two specks of white came flying through the air and alighted on the roof of the summer kitchen that the boy had carried them to when they were young and helpless. 


\section{CHAPTER XV}

THE SHORE BIRDS AND WADERS

7 HOUGH the Killdeer belong to the order of shore birds and waders when with us, fortunately for the farm, they spend more time in the pasture than along the shore.

There are some pairs of Killdeer that have nested here for many years and have become so tame that they will run along directly in front of us when we go out to catch the horses or drive in the cattle. As runners they excel most other birds. They will run along over the ground until a stranger might suppose it was their only way of crossing that field and that their wings must indeed be small and weak. Then, suddenly, they will raise their wings and fly, not high, but usually just above the ground. If they have been startled they will utter a peculiar note of alarm at the moment they cease to run and spread their wings to fly.

Their wings are a surprise to those who have only seen them run. They are by no means 


\section{B I R D OF PEA SEMAR S H}

small, but big and powerful looking and beautifully marked. It is only in flying that the Killdeer's plumage shows to advantage. But they do not fly far. The chances are they will alight on the first stone or mound they come to and wait until your approach and then trot along ahead again, flying only when you have almost reached them.

They nest in the fields, if four eggs on the ground could be called a nest, and in such unprotected spots are their eggs frequently found that one wonders that little Killdeer are ever hatched. Sometimes they do not even take the precaution of laying their eggs on the sod, often in seeding time they are found on the ploughed land. One day when the men were rolling a field they came upon a Mrs. Killdeer sitting upon her four clay coloured eggs. They moved the eggs, Mrs. Killdeer following, though protesting, and settling down upon them when they were placed upon the ground again. Before the field was sown the eggs were moved four times, yet in due course the little family was hatched.

Of all the odd-looking little creatures the baby Killdeer are the oddest. Their little [ 130 ] 


\section{B I R D O F P E A S M A R S H}

heads look like tassels, and when they run they are like tassels blowing away. As soon as they are big enough to move about they must follow their mother when she is catching their meals, for she will not bring food to them any longer than is necessary. By following her up they learn how to hunt for themselves, for soon, very soon, baby birds must make their own way in their world of dangers and disasters.

The food she is catching for them consists of earthworms and insects, beetles being a particular delicacy. Hunting over the fields from morning till night a family of Killdeer will dispose of a large number of injurious insects. They are the farmers' friends and he may well stop the team to move to a place of safety the Killdeer's eggs when he comes upon them.

Only towards autumn do these birds leave the farms where they nest and gather in flocks along the shore of rivers and lakes. They are meeting to arrange for their long journey south, where they must go when the frost comes and they can no longer find food with us. They must use their beautiful wings now. Perhaps there is something in the philosophy of the small boy who said they ran in the summer in- 


\section{BIRDS OF PEASEMAR H}

stead of flying to save their wings for the long fly. In any case, it is on the wing that they bid us good-bye, leaving our meadows silent and lonely. But their haunts in the south will not make them forget their old nesting places. Some bright morning next April we shall hear their cheerful, "Kill-deer, kill-deer," and there they will be, circling about and settling down upon the same old stones and mounds, or hunting their food about the little ponds which melting snow has left in the hollows.

One June day, we made the discovery that a family of weasels had made their home under the old stone fence on the edge of the pasture. In vain we laid in wait for those crafty enemies of the birds. That night, sleeping in a tent, we were awakened by the Killdeer cry of alarm. Had the weasel crept stealthily upon a young Killdeer sleeping soundly, its head tucked under its wing, on one of the big, flat stones, a favorite resting place? It was impossible to tell what tragedy had been enacted.

Closely related to the Killdeer and much like them, are the Snipes and the Sandpipers, that make lonely spots on the beach so full of life and cheer. Along the Nottawasaga Bay 


\section{BIRDS OF PEASEMARSH}

where the sand on the beach is packed hard and one can motor for miles along the water's edge, flocks of Sandpipers will sometimes fly just ahead of the car, stopping to look for food now and then when they get a little way ahead, but taking to wing again directly the car overtakes them, as if they enjoyed the race and gloried in the fact that they were always ahead.

Well it is for the Sandpipers that they can fly in safety so close to man. They have more unfortunate cousins that would not dare to do so, lest they should not be left alive to win the race. The Curlews and the Woodcock are these relatives, unfortunate and always in danger because they are game birds. The sad story of the Esquimau Curlew that nested in the barren lands of the north, and for its winters flew many thousands of miles to the south, is mentioned in a succeeding chapter. Men lost sight of the fact that the living bird was valuable as an insect destroyer, and shot them for the market in coast towns when they brought but a few cents each. As grasshopper destroyers alone the Curlews were of much economic value to man; passing, as they did, in large flocks over so great an extent of territory, they 


\section{B I R D OF PEASEMARS H}

frequently arrived in some district just in time to check the devastations of a plague of grasshoppers, or some other injurious insects destructive to vegetation.

The Woodcock would be with us now in all our woods and swamps had it been protected. "It is the game bird" writes one ornithologist. This is the reason of its going. That it is migratory makes its protection a very difficult matter. The Woodcocks may fly away in the autumn and not be alive to return in the spring. They are sometimes called Night Pecks or Bog Birds. That is because they thrust their long beaks into the soft earth for worms. The beaks are perfectly straight and longer than the head, soft and very sensitive. They seem to know by feeling the earth with their beaks in just what particular spot they will get the worms.

The eggs, usually four, are laid, in most places, before the end of April, earlier by those that nest farther south. Their nests are on the ground among the leaves and sticks. When danger threatened their little ones the Woodcock have been known to carry them away by holding them with their feet as they flew. 


\section{B I R D O F PEASEMAR S H}

The large, beautiful eyes of the Woodcock are dimmed by the light, and it gets its food mainly at night in the swamps and low meadows, but in very wet seasons it would sometimes hunt on higher land, while in dry seasons it would resort to the creeks and the banks of the rivers.

The poor Woodcock has been persistently pursued in spring and summer, in nesting season and out of nesting season, and in the winter when it migrates to the south. It has been hunted in daylight when the light has dimmed its eyes, and at night when it has been dazzled and confused by lanterns and torches. The wings in flying make a whistling sound, and when in open meadows it thus draws attention to itself and is easily shot.

In writing of the Woodcock, Baird, one of the best authorities, says: "In past days it resorted in the winter in very large numbers to the low land that borders the Mississippi. It was safe there from ordinary hunting, but 'fire hunting' was resorted to in the following manner. The sportsman, armed with a doublebarreled gun and wearing a broad-brimmed hat, proceeds, on a foggy night, to these [ 135 ] 


\section{B I R D OF PEA S M A R H}

marshes. A stout negro carries on his head an open vessel supplied with burning pine knots. The hunter follows the torch bearer, his eyes protected by his hat from the glare of the light. The birds are seen sitting about on the ground, staring in dazed bewilderment, and are often killed in great numbers in this illegitimate manner."

The help that bird sanctuaries can give in bringing back this bird is the only thing that will save it from complete extermination. Everyone who owns a bit of property on which there are low, wet fields, marshy grounds and woodland, the favorite resort of the Woodcocks, should endeavor to encourage and protect them. There is always a chance that some may return in safety in the spring and that the numbers will increase. As insect destroyers they amply repay for any time and trouble taken for them. Their food consists of worms and several kinds of larvae which they find under leaves and the debris of swampy woods. But the real reward is far beyond material things. It is the securing for future generations of a valuable wild bird that is in our keeping. To secure success international inter- 


\section{B I R D OF PEA SEM A R H}

est should be taken in the saving of this bird, otherwise when protected in one country it would be shot in another. Every sanctuary that gives it safety and a home is doing something towards arousing interest in the protection of this bird which alone will prevent its going.

As the birds belonging to the order of Shore birds and Waders nest on the ground, their greatest four-footed enemy of recent years is the homeless cat. The settling of the country has brought them nearer the habitation of man, where the cats abound. Occasionally their eggs are trampled by sheep and cattle. Killdeer, Snipe and Sandpiper are not very particular where they deposit their eggs, and the settling of the country has not deprived them of nesting places. But the Woodcock is not so fortunate; with the disappearance of the woodlands invaluable springs are drying up. A bit of swamp where there is good cover and plenty of old stumps and fallen logs, beside which they like to nest, is not often found in a farming district. 



\section{CHAPTER XVI}

\section{GEESE, SWANS AND DUCKS}

T'T is in apple picking time that the flocks of wild Geese pass over Peasemarsh on their way to the south. When the first flock was seen last fall there was such frantic shouting to us from the orchard that we rushed out fearing some of the boys had fallen from the long ladders that reached to the top of the spy trees. Reaching the orchard, breathless, we were greeted by the reassuring, "Look at the wild Geese! Look! Quick!" We looked, and there flying through the air was a noble squadron of Canada Geese. The peak of the Blue Mountain so near the shore a few miles to the south-east causes them to fly high, unless they rest at the mouth of the Indian River, or in the sheltered bay below. Several flocks rested there last fall, and in the early morning were seen rising up from the water and setting out upon the journey southward. In the early spring they pass again northward, homeward. 


\section{B I R D OF PEASEMAR H}

That flocks are left alive to migrate says volumes for their intelligence.

The most beautiful relative of the wild Goose is the wild Swan. A few are still left and every spring make their way to their nesting places in the Arctic. One of their greatest dangers of the journey is at the great waterfall of Niagara. Frequently they alight at night in the smooth water above the fall and when asleep are apparently carried down into the current, and then nothing can save them from being swept over the falls. Often some are wounded by being swept against blocks of ice, others are only stunned and would recover and go on their way, but frequently are killed by men that lay in wait for them. Geese and Ducks are also sometimes taken in this way. It is to be hoped that the migratory law for the protection of birds can be enforced to prevent these noble travellers from being slaughtered while struggling to free themselves from the danger of the mighty waterfall.

A wild Swan was found recently wounded on the ice on the shore of Lake Erie, near Dunnville, by a Mr. Docker and rescued by him. This magnificent bird had met with mis- 


\section{B IRDS OF PEASEMARS H}

fortune when it had still thousands of miles farther to fly to its home on the Arctic shore.

It has always been hard to protect the wild Ducks here. Years ago they were very numerous, but they disappeared rapidly as rifles became more plentiful and motor cars brought the gunners from neighboring towns, but now that they have special protection here a few have come back.

On the other side of the river is a pond long known as the Duck pond, having been given its name in happier days for the Ducks, when they dared come in large numbers to the Georgian Bay. At one time this pond measured over a hundred rods in diameter. Children were warned to be careful when boating or skating there, for the pond was very deep; in fact it was vaguely whispered that it was bottomless. Around it grew reeds and bushes that sheltered the Ducks.

But alas for the great pond! the fire got into the bush around it, and before it could be checked most of the trees about the pond were swept away. After this it dwindled until it became but a small frog pond, with no shelter about it for the wild Ducks. The Ducks that 


\section{B I R D OF PEASEM A R H}

come to the shore now resort to the sheltered bay.

"What good are they if they are to be protected so you cannot shoot them?" is a question frequently asked. Those who take no pleasure in the homeward flight of the weary travellers that have covered thousands of miles exposed to every danger, should consider the history of the birds. When the white man first came they were everywhere. When Montreal was but a group of huts, the little Ville-de-Montreal, it was but a few minutes' walk to flocks of innumerable numbers of Ducks. This was what the white man found when he came. Has he any right to wipe them out of existence so that his children and his children's children will never see them? $\mathrm{He}$ has gone a long way towards wiping them out already, and each year they are growing still less. It is time to let the wild Duck migrate and nest in safety. To the success of the protection of the sanctuaries depends the increase here, for men who do not need them for food will gain access to their haunts and disregard any laws limiting the number allowed each hunter. 


\section{B I R D O F P E A E M A R H}

There are many incidents to prove that Woodducks, Mallards and Golden Eyes can be attracted by safety and food to suitable nesting sites. The Mallards, as they make their nests of sticks, grasses and feathers on the ground, require only the necessary environment, but the Golden Eyes and Woodducks, nesting in hollow trees, can be supplied with nest boxes. There are incidents when Golden Eyes have nested in chimneys. It is said that when young Ducks, hatched therein, are ready to leave the nest, the old Duck sits on the top of the chimney and waits for them to climb up, fall over the edge of the roof and from there fall to the ground. Strange to say this adventurous entering of the outside world has no ill effect upon them.

In the swamp here we hope to re-instate the Woodduck, the most beautiful of all its family, and believed by some to be the bird nearest extinction. Years ago it was distributed all over the wooded portions of Ontario, arriving in the province about the time the ice disappeared from the lakes and rivers. Hollow trees near water were always likely to contain a Woodduck nest. When [ 143 ] 


\section{B I R S O F PEA S M A R H}

ready to leave the nest the young would have to scramble up and fall over the edge, or else be carried out in the mother's bill. The story of an early settler here comes to mind. Working in the bush near a stream he sat down for his noon-day lunch and presently discovered that just in front of him was a Woodduck tree and that the mother bird was carrying her offspring one after the other out of the tree to the side of the stream beyond. This shows that Woodduck nest boxes should be not far from a pond or stream to be suitable, for the ducklings must be taken to the water while they are still small.

In writing of this bird Coues says, "The spring shooting on its breeding ground has made it rare in many places where it was once common."

And McIlwraith in his "Birds of Ontario," says, "Owing to their great beauty these birds are much sought after by all classes of sportsmen and are now seldom seen, except in retired ponds and marshes where they breed."

Wild Ducks have been frequently domesticated. An instance is mentioned by Baird where wild ducklings taken when young were 


\section{B I R D OF PEA S E A R S H}

fed freely on cornmeal soaked in water, and when they grew up "caught flies with great expertness."

The story of little Quack, told by a cousin of a Canadian Ornithologist, who spent her childhood in Muskoka, shows how companionable they will become. Little Quack belonged to a family of ducklings whose mother had come to grief. They were rescued by the children of this family, taken home and given to a mother hen. Every day they went swimming in the stream, the frantic foster mother cackling, flapping her wings, and running down stream after them. Weasels and other four-footed bird enemies living along the stream learned to watch for their daily swim, and each night the hen came home with a duck less, till only one was left. To save this one from the dangers of the stream the children took it to the house. They named it Little Quack and it soon installed itself as a member of the family and learned to waddle along behind the children wherever they went. It went to school with them, and would hide under the desks until school was out. On the way was a little bridge it could not cross itself, and would al- 


\section{B I R D O OF PEASEMAR S H}

ways wait to be carried over, calling after them if they forgot to do so. It learned to know the friends they visited, and had its favorites among them. At one house was a little child that would pull it about and disturb its feathers, which it disliked intensely. When they arrived at this home for a visit Quack would disappear, but was always within hearing. When they were ready to go home they would say, "Come Quack, we are going," and Quack would answer from the dark corner under some chair or sofa and out he would come. 


\section{CHAPTER XVII}

\section{MIGRATION OF BIRDS}

THE flock of wild Geese flying high, like specks against the grey November sky, is one of the greatest wonders in the world of feathered things. They have come from their home in the far distant Arctic, and there among the clouds they are heading straight for their winter home hundreds of miles away. For weeks before the Geese fly south, flock after flock of smaller birds have been going, some disappearing in the late summer, others in the early autumn, others when cold winds are blowing and the Geese are flying south. The few migrants that are left are gathering in flocks and any morning we may find them gone. Where do they go, and how do they find the way?

In the old days when the Redmen sat about their campfires watching the shadows grow deeper, they pondered over such great mys- 


\section{B I R D OF PEA SEM A R H}

teries as the setting of the sun, the rising of the moon and the blowing of the wind, and among these was that mystery of the autumn, the passing of the birds. About those wigwam fires strange tales were told of warriors that had travelled down the great streams and had come upon flocks of birds feeding among the trees and shrubs that were never leafless, and bathing in the pools that were never,frozen; and there grew among the Redmen a legend of the travels of the birds. It seems that when the Great Spirit first sent the Snow Chief down to earth He made pathways in the sky with fleecy cloud flecks that only birds could see, and all those birds that could find no food when the Snow Chief reigned over the land, were to follow those pathways and they would lead them to food and warmth and sunshine. But when the Snow Chief took his robe of snow and ice from off the earth they must return again to the old nesting places. And ever since along those pathways in the sky the birds have travelled every autumn and homeward every spring.

The White man simply says it is the birds' sense of direction that shows them the way. [ 148 ] 


\section{B I R D OF PEASEMAR S H}

But as to why they go by certain routes he gives no answer.

So far north as this one seldom sees the large flocks of birds that gather together in migrating season in the region of Lake Ontario and Lake Erie, but the birds that have nested here gather in small flocks before starting away. Sometimes many of them disappear early in the season, but very few have really gone. They are merely off along the lakes and rivers or in the fields and woods. For the education that must be given the young birds before they set out upon the long fly these birds require a wider stretch than their nesting sites. The little ones must try their wings and learn to avoid the dangers by the way. The most remarkable thing in the migration of birds is that the nestlings of a few months before set ont upon that stupendous journey. Many of t!ee birds that have nested in the sanctuary come back to the old nesting place as if they were saying good-bye. Then some morning we awake to find them gone.

It is impossible in one short chapter to follow the journeys of all our birds. The story of these wonderful travels would fill many 


\section{B I R D OF PEASEMAR H}

volumes. But by considering the distance travelled by a few of the best known birds one can form some idea of the migratory flight.

Many of the birds that nest with us go upon a very long journey, some to the Central or the Southern parts of South America. Our Bobolink winters in Brazil. He seems to time his journey so that he reaches the rice fields of the different states through which he passes, when the rice is at its best. So regularly does he appear that he is called in some places the rice bird. Our Green and Yellow Warblers cross the Gulf of Mexico. We are told that often they are overtaken by storms that force them down nearer and nearer to the surface of the water. When their plumage becomes soaked and heavy, flying against the wind is almost impossible, and many are caught by the crest of the waves as they dash up. Others, becoming exhausted, drop into the water. After storms in migrating season the shore for miles is sometimes dotted with the bright colored bodies of these little travellers.

When the Blackpoll Warbler rests for a few days in the orchard one cannot look at it without marvelling that those tiny wings can take 


\section{B I R D OF PEASEMAR S H}

it on so great a journey. It, too, will cross the Gulf of Mexico, but it has already flown thousands of miles from its nesting place in the Arctic.

Our Chimney Swifts winter in Central America, our Barn Swallows in the tropics. Our Kingfishers and Yellow Billed Cuckoos have been known to visit Bermuda. Some birds that nest in the far north, winter in the southern part of South America. Others, like the Robin and the Blackbird, do not winter farther south than the southern part of the United States.

The small birds, such as Wrens and Warblers that cannot fly fast enough to escape birds of prey, migrate by night. The shy, retiring birds, such as Thrushes and Woodcocks, also migrate at night. Those that migrate by day are the strong flyers like the Blackbirds, Swallows and Crows, or those birds which in their native haunts are not so shy and retiring and are accustomed to making long flights where they have not much cover. Among these are the Robins and Bluebirds and some of the Finches. Strange to say the Hummingbird is among those birds which migrate by day. But 


\section{B I R D OF PEASEM A R H}

the Hummingbird knows that its wings are a marvel.

It is remarkable that the birds should know when to start and where to meet in flocks for the journey. But the greatest wonder is that they find their way, though they fly too high above the earth to be guided by it. Often one flock of the same species will be days behind another, yet they keep to the same route, as if, according to the Indian Legend, they really had pathways in the sky.

The return flight is equally wonderful. After their travels of many thousands of miles the birds not only find their way back to the particular garden, or orchard, or tree clump, or stream where they nested the year before, but they arrive there at almost the same date each year. Some cold day in March we waken to hear our little Song Sparrow, one of the first to tell us that spring is coming; a little later we hear the Meadowlark and the liquid notes of the Bluebirds that have returned to their last year's nest box. One after the other they all come home, each announcing its arrival in its own peculiar way. It is usually about the first of May before the Wren is singing on his 


\section{B I R D OF PEASEM A R H}

nest box, and Mrs. Wren will follow in the course of a few days.

It may be that we miss some of the last year's guests. The sad part of migration is that some will fall victims to the perils by the way. To the dangers of the journey that have always existed, man has added many more. His lighthouses are a deadly allurement. Innumerable birds, attracted by the lights, strike against them and are killed. Telegraph and telephone wires are sometimes fatal obstructions to birds at night, or when struggling in blinding storms. But still more serious have been the ravages of the gunner and the plume hunter, who find their work easiest in migrating season.

Fortunately the birds have staunch friends among the human beings who have long contended that feathered travellers should be wards of the Government and have safe conduct on their journeys. The International Treaty between Great Britain and the United States for the protection of migrating birds in the United States and Canada, passed in 1916, is the greatest step that has ever been taken in this direction. If this law is enforced through- 


\section{BIRDS OF PEASEMAR H}

out these countries it will undoubtedly result in the increase of many forms of bird life, but especially game birds and large, rare birds.

It is a sad fact that it was the coming of the white man that made such a law necessary. The Indian in his original state looked with reverence and wonder at the bird world. Though he took birds for food he apologized to them for doing so, pleading his necessity, and wishing them all good things in the spirit world. To the red man the wild things were little brothers. When that sense of reverence and comradeship for all living things gave place to our materialism only carefully enforced laws could save birds from being slaughtered when on their wonderful journeys.

But though we have shot the Albatross we have stories to show that comradeship for wild creatures did exist sometimes among the pioneer white men.

Not long ago an old man of the passing generation was telling of a night many years ago in his lonely log house. An early fall storm of wind and sleet and snow had been raging most of the day, and, as night descended, there came down about his door a flock of wild 


\section{B I R D OF PEASEMAR S H}

Geese that had struggled against it as long as they could. Wet, bedraggled and weary they sought shelter under the projecting roof of his cabin. There they remained until the early morning.

"And did you not have a shot at them?" asked the youth of to-day.

The old man of the generation that is passing looked at the boy of the generation that is coming and answered,

"No."

He looked out across the broad fields beyond. He looked again at the boy and said:

"There is room for all earth's travellers." 



\section{CHAPTER XVIII}

NEED OF PROTECTION FOR BIRDS

$7 \mathrm{HE}$ feathered creatures live in a world beset by dangers. Each year hundreds and thousands meet some tragic, untimely end. Many times they are overtaken by storms and either perish from the elements or starve to death because in a world of hurri.. cane and sleet and rain they cannot get their food. On all sides they are in danger from natural enemies of the wilds that have hunted them from earliest times. But by far their greatest danger has come from man and the enemies that man has brought to them. When one considers what the birds have done it seems incredible that from him they have had most to fear.

The storms cannot be prevented, but the little feathered creatures need any protection from them that can be given. Often they are sadly in need of food when their natural sup- 


\section{B I R D OF PEASEM A R H}

ply is cut off by the elements. In extremely cold weather it is only food which keeps their little bodies warm, and if they cannot get it they soon perish. When snow is very deep the seed-eating birds are entirely dependent upon what they can gather from stray stalks that rise above the snow. Frequently even these are covered by drifts, and then such birds as Quail are liable to starve to death in large numbers. Supplying food in sheltered places is a great help to both resident and migratory birds, especially the early comers that are liable to be overtaken by storms.

To protect the birds from their natural enemies is not always possible. For the birds that come to our own premises, however, much can be done towards keeping down wild creatures that prey upon them. By doing this not only will the birds already there be protected but their numbers will rapidly increase, for safety is the greatest attraction that birds can have. Abundant food supplies will draw them to a spot, but freedom from danger means much more. Scarcity of food they can overcome by flying long distances and hunting late and early, but they are no match for snakes, crows, 


\section{B I R D O F P E A E M A R H}

weasels, skunks, or the great grey Owls when they come upon them unawares or carry off their nestlings.

But since the greatest danger has come from man, it is from him that they most need protection. There is an old well-known story of a king who was very fond of cherries and had some fine specimens growing in his palace garden. One day, it seems, he became very angry because he found a bird pecked one among those brought to him and he straightway made a law compelling all the men to turn out and kill all the birds in all the kingdom. So this was done, and he expected that now he would have beautiful cherries and not a bird-pecked one among them. But, alas for his hopes, he had no cherries at all. The insects that the birds had lived upon attacked the trees in such hordes that soon they all died.

That mistake, made long ago in olden times, has been repeated year after year. The shooting of Robins in cherry trees has not ceased. The only thing that will protect the Robin is education in the value of birds. The Robins are naturally insect eaters and if they are seen helping themselves to a few cherries, who would 


\section{B I R D O F P E A E M A R S H}

begrudge a few sour cherries to so hard a worker as a Robin? They are only taking that to which they have earned a right. Had the unfortunate king known what would happen if the birds were gone he would doubtless have spared them.

If all the birds have done for trees were recorded it would be much more than human owners have done. Education and interest in the value of birds will in time protect them from the ignorance and thoughtlessness of human beings. Children who learn to attract and protect them, and watch and study them, will never grow up to give them anything to fear. They will never make the Robin, or the Barn Swallow, or the Meadowlark their targets. With a large proportion of the human race the birds are coming into their own.

There are some, happily a very small proportion, however, who have done dark deeds in the world of birds with their eyes wide open. They are those who seem to have no thought for anything beyond petty dollars, and so long as their dark deeds will bring them dollars there is little hope for the birds they have wronged. Strenuous laws may keep them in 
B IRDS OF PEASEM A R H

check, but usually their deeds are carried out far back in the wilds where they can escape the law. Knowledge of their work given broadcast to the world may prevent a market for their produce, and this alone would bring to an end their crimes against the feathered creatures.

The misery and destruction that man has brought upon birds for a little gain is one of the saddest stories that history has to tell. Beautiful plumaged birds have suffered most. Among these were the Great White Heron and the White Egret. The Great White Herons, which nested in colonies, were at one time abundant in different parts of the United States, and feather dealers sent men out to their nesting places, because at nesting time their plumage was most beautiful, and also because they were then easiest to get, for no terrors would make them leave their helpless little ones in the nests. The men hid in the bushes and shot the parent birds as they came to the nest with food.

Deceitful means were also used to get these birds. Sometimes a wounded one would be placed in a thicket, round which the men hid, 


\section{B IRDS OF PEASEMARSH}

knowing that by its calling it would attract others to it and they could then be shot.

What did these hunters care for the little ones left to call vainly for mothers that would never come again? Night came on and no mothers' wings were spread protectingly over them. The cold grey morning came and they called again more faintly, and still more faintly, until they were too weak to be heard. Soon they, too, were dead. But what did the men care? They were to receive a few paltry dollars, and thoughtless women would wear the feathers taken from the dead parents of the dead baby birds.

There have been lonely islands where beautiful birds have made their homes, changing the dull rocks and sands to a spot of beauty and song. Market hunters have found them out and visited the islands, leaving them desolate spots, strewn with the mutilated bodies of the once lovely feathered creatures. And all this change because the feathers are used for millinery purposes and desired by women who ignorantly fancy they make them more attractive.

The story of the beautiful Heron and the story of the Snowy Egret, whose feathers are [ 162 ] 


\section{B I R D O F PEA S E M A R H}

torn from it while it is still living, should be told in every millinery store, and to every woman who wears them, told over and over again until, instead of the beautiful plume in her hat, she sees only the wounded bird. Then, perhaps, the hunter will have no market for the produce of his murder. But until that time only the most carefully guarded laws will protect the birds of beautiful plumage.

How much such laws need to be carried into effect is shown by the history of bright plumaged birds that have been almost wiped out of existence. The Great White Heron and the Egret, once so numerous, have become very rare. The Trumpeter Swan and the Whooping Crane are almost gone. Even our tiny, bright colored songsters sometimes fall a prey to the plume hunter.

But it is not only millinery purposes that are causing the destruction of birds. Side by side with the loss of bright plumaged birds comes the loss, in some cases the extermination, of those that come under the head of game birds. Hunters who cannot be called sportsmen are responsible for the extinction of valuable birds and the decrease of others to such an alarming 


\section{B IRDS OF PEASEMARSH}

extent that without greater protection they, too, will be gone.

The story of the Esquimau Curlew is one which everyone should consider. No story sounds a clearer note of warning. Eighty years ago these birds migrated in great flocks of many thousands. Far in the north they nested, from Alaska on the west to Labrador on the east, while the Barren Lands, the land the Indians who accompanied Hearne to the Arctic Sea, called the land of Little Sticks, because only stunted trees grew there, was their favorite nesting place. Their winters were spent in the southern part of South America, near Cape Horn. Twice each year their wings carried them the length of two continents. Fortunately their nesting places were so far north that they could not be slaughtered there, for few white men could reach them. There were no fast trains to the Barren Lands of the Arctic, and the Indians and Esquimaux, as we have seen, were not guilty of exterminating wild creatures. Any not needed for food were allowed to live. It was the white man who wiped out the Esquimau Curlew. He attacked them when in dense flocks they made their [ 164 ] 


\section{B I R D OF PEASEMARSH}

way south in the fall on that long, long flight from the Arctic to the southernmost part of America. On the way they had well-known resting places. Men found out these resting places and the date at which the Curlew were due there, and fell upon the weary birds as they alighted. At some places when they were roosting at night on the beach banks, packed close together, men went out with lanterns and slaughtered them by hundreds and thousands. They were killed off Labrador, off Newfoundland, off the New England coast, at any spot where they attempted to rest.

Terribly decreased in numbers they at last tried to escape their human enemy by changing their course, flying, instead of along the eastern coast, inland as far as the Mississippi. They were only to find that the human beings who should have protected them were there also to kill them. The fact that they were wonderful birds, with almost human instincts, only helped in their destruction. If one were wounded and called to the others they would come back to it and hover round it. In spite of their own danger they would not leave it and men, no better than savages, taking advantage 


\section{B I R D OF PEASEMARSH}

of this, would shoot them down even as they tried to help a wounded comrade.

That wonderful flight is a thing of the past. The flocks of Esquimau Curlew are gone. Within the last few years, it is said, that only occasional specimens have been seen-and shot. Even now, when the story of the Curlew is known, those few rare birds have not been left in safety to increase their numbers.

That far northern land of "Little Sticks," by nature the home of these valuable birds, is now a lonely spot. The nesting season comes and goes. There are no more dense flocks of Curlews. It is indeed a barren land.

Still more numerous at one time was the Passenger Pigeon, known throughout Canada and the United States. These birds abounded in such flocks that their flight is said to have darkened the sun. But alas, they, too, have gone. They were slaughtered at their nesting season and as they migrated. The story of the Passenger Pigeon gives the most forceful proof that no birds, no matter how numerous, can long withstand the attacks of man in their breeding grounds. Too late men awoke to the fact that they had completely wiped them out. 


\section{B I R D O F P E A E M A R S H}

In the old home of the Pigeon they had become extinct.

The changing condition of the country, for which man is responsible, is the cause of one of the greatest needs for the protection of birds. Bush, shrubs, clumps of bushes, long coarse grass, weeds, brush heaps, hollow stumps, trees, and old rail fences have been rapidly disappearing, so that the birds have but little hiding place. They are exposed to danger from their old enemies, the wild things, and to danger from man and the enemies he has brought them, among which the domestic cat is the most deadly. Not only are cats a serious menace to full-grown birds, but those that nest on the ground have no safety where cats exist in large numbers, or where homeless cats are allowed to roam.

The clearing of the land and the existence of the cat has had as much to do with the decrease of Quail as have the most unscrupulous gunners. Little Bob-White's nestlings have again and again been devoured, the whole nestful at a time, by that sly, watchful, green-eyed enemy that creeps near on padded feet and springs upon them unawares. 
B I R D OF PEASEMARS H

All that are left of our game birds are in danger of extermination. Any occasional pair that might happen to venture near the habitation of man should be carefully guarded. Unfortunately they are usually hunted until they, too, are gone.

As the land has been cleared and the birds find less natural protection, the weapons for their destruction have become more deadly, and, with a network of railways, motor boats, and motor cars, the means of reaching their haunts more rapid and direct. Without greater protection from man the last remains left to us of the once great flocks of these shy, wild, feathered things will be wiped out and we shall see when it is too late that they have vanished from the earth forever. 


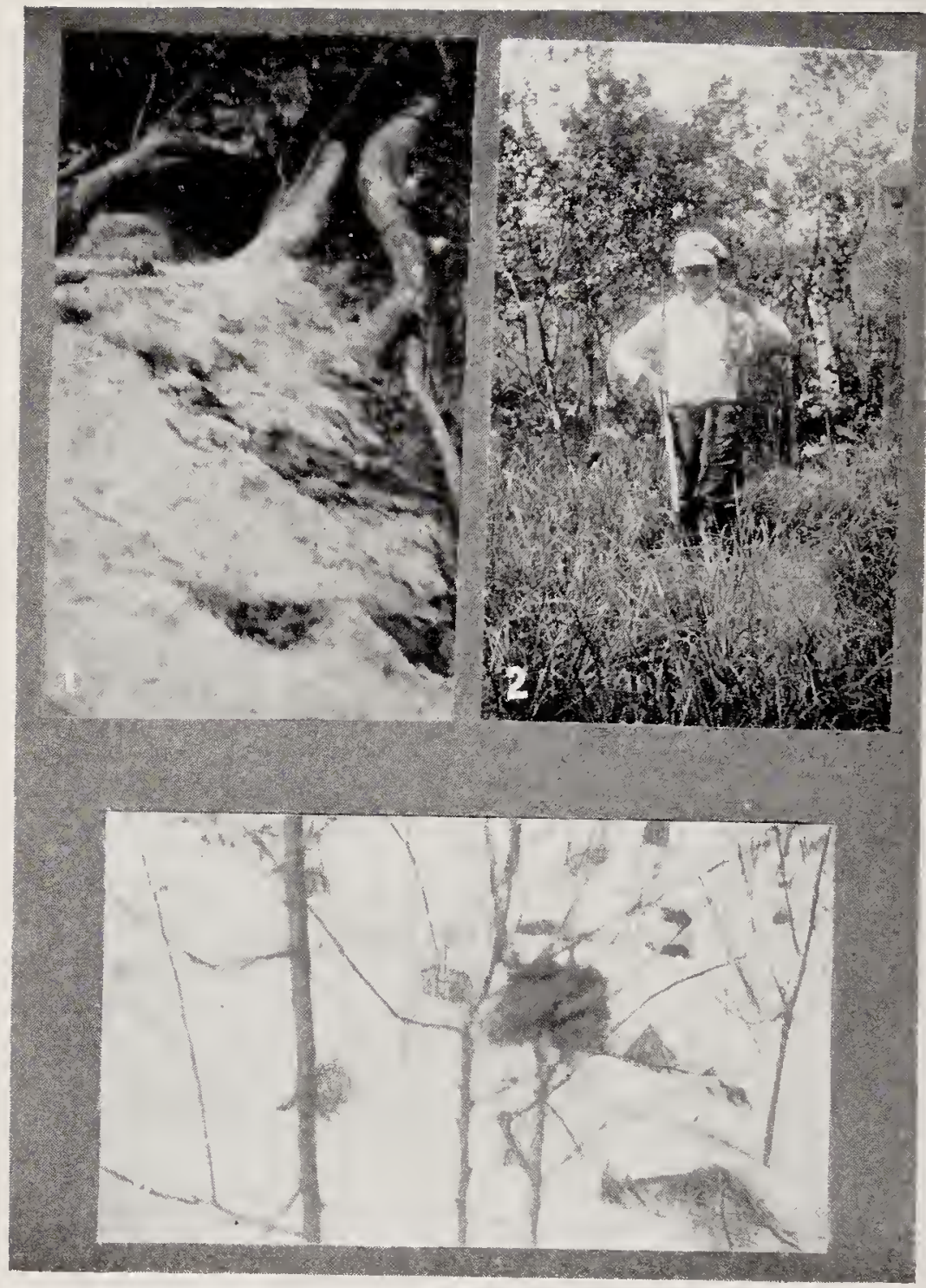

1. I fox hole in the bank. (Page 168.)

2. One red squirrel less. (Page 169.)

3. Indigo Bunting's nest. (Page 205.) 


\section{CHAPTER XIX}

FEATHERED AND FOUR-FOOTED BIRD ENEMIES

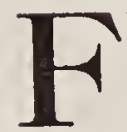

EATHERED enemies are those from which it is very difficult to protect our small birds, and unfortunately some have been rapidly increasing in numbers. Much has been written of the good qualities of the Crow, of his sins perhaps we have not heard enough. It is not easy to condemn in wholesale fashion a bird that figures so largely in fables of our childhood, and that school books from time immemorial have termed the wise old Crow. In spite of tradition, however, the Crow has become, in some districts, one of our most serious bird enemies.

In the old days, the days in which the fables and the early school book stories originated, the Crow was not so serious an enemy of our smaller birds, for comparatively they were not so numerous. They had enemies of their own to keep them in check. Huge Owls were the terror of the Crows at night, and Eagles and 


\section{B IRDS OF PEASEMARSH}

Hawks, besides four-footed enemies which do not now exist in cleared farming districts, depleted their numbers. What Crows there were then had to be on the alert for their own enemies and were not so likely to go bird-nesting. They knew that if they attempted to move stealthily about watching some bird to see where its nest was, they were very likely to be pounced upon by a creature bigger than themselves, whose approach they had not noticed. So the Crows did not increase so much in numbers and were not able to cause the decrease to any extent of the song birds. Nature preserved a balance.

Since the days of the writing of the fables man has interfered much with the balance of nature. With his coming and the clearing of the land the enemies of the Crows have almost gone, and the consequent increase in the number of Crows has been a great drain on the Crow food supply. A hungry Crow will soon acquire the bird-nesting habit, not only robbing the nest himself, but passing on the habit to his children and his grandchildren. The fables hold good so far as the wisdom of the Crow is concerned. Clever criminals are the most dangerous, so the Crow soon becomes an adept 


\section{B I R D OF PEA S E A R S H}

in bird-nesting. When food is scarce there is not a nest on the hill-side the location of which he does not know; he knows, too, when the nestlings will be big enough to make a meal. When a Crow is seen moving silently about among the trees, usually in the early morning or late in the day, one may be fairly sure of the business he has in hand.

During the last few years the Crows have been very troublesome here. They are especially on watch for the young Robins, and have been known to come up almost to the house and carry off a Robin that had been for some days out of the nest. They have done this in spite of the most frantic efforts of the old birds to ward them off. The smaller birds are almost entirely at their mercy where European Sparrows are allowed to nest about the buildings, for it drives them farther out, where they can have no protection. Since man is responsible for the increase in the Crow population, he owes it to the small birds to step in and re-instate the balance of nature. The Crow enemies cannot be brought back, but the number of Crows can be lessened in every district where they are too numerous. In coun- 
B I R D OF PEASEMARSH

try places it has become of vital importance that small birds should be protected from them.

All that has been said of the Crow applies also to the Crow-Blackbird, and applies with emphasis, for the Blackbird will glide in and out of the thickets where the song birds nest, escaping our notice more easily than a Crow. The Blackbird has also increased in numbers and unless kept in check but a small proportion of the nests of the song birds can escape.

Another bird, the Shrike, has been known to take not only nestlings, but the adult birds where they can be obtained. Somewhere near the farm a pair of Shrikes have nested for two years in succession and evaded all efforts to induce them to move their housekeeping operations farther on. Their lookout point is usually a telegraph wire along the road near the river. The boys when fishing one evening saw a Shrike pounce upon and kill a Bluebird. The Shrike, however, is an insectivorous bird and protected by the Migratory Bird Convention Act.

A bird that has a different way of exterminating nestlings is the Cowbird. Where a Cowbird egg is deposited in a small bird's nest it 


\section{B I R D O F PEASEMARSH}

usually means the destruction of the rightful nestlings. The large Cowbird egg takes up half the room in the nest, and the big birdling hatched from it will very likely squeeze the little birdlings out altogether, or crush the eggs before they are hatched. Warblers' nests should be examined wherever possible and any Cowbird's egg found there removed. Sometimes the birds will build another story to the nest, above the Cowbird egg, and there have been cases where the Cowbird has returned and laid an egg in the upper story.

In some localities it is claimed that the Bluejay destroys as many eggs and nestlings as the Blackbird, but with us it has never been the case, as the Bluejay exists in very small numbers and does not haunt the orchard and gardens in all seasons as do some other birdnesters.

Besides these feathered enemies there are those commonly called birds of prey, certain Owls and Hawks, but as these prey upon domestic fowls as well, they will always be more or less kept in check, and besides they destroy a great many bird enemies, which to some extent balances the injury they do. Even the 
B I R D OF PEASEM A R H

Screech Owl, usually considered a beneficial bird, will devour small birds, catching them when they have gone to sleep at night; and the Great Horned Owl is very destructive to bird life. But be this said in his favor, he sometimes kills Crows. He also destroys a great many rats and mice. The Great Grey Owl and the Snowy Owl occasionally visit us, but only in severe winters, and when they come the Chickadees and Nuthatches usually disappear, returning again when the Owls are gone. Hawks will never become very numerous in the settled districts where poultry is kept. It is a mistake, however, to condemn all the Hawks, for some are very beneficial, and while they may take some small birds, they destroy a great many bird enemies. Probably the least harmful is the little Sparrow Hawk, as it lives mostly on mice and grasshoppers. The handsome Marsh Hawk might also be classed among those not objectionable. There are others, however, that would be a great menace to the birds were they allowed to become numerous. The Sharp Shinned and the Coopers Hawk are the most destructive to bird life.

Of the four-footed enemies happily a few, such [174 ] 


\section{B I R D O F P E A E M A R S}

as bears, wolves and wild-cats, have disappeared with the settling of the country. But where they have gone the cat has come. The cats, like the European Sparrows, have been brought by man, and unless man will keep them in check they will become a still greater menace to bird life. Some cats are inveterate bird hunters, apparently preferring them to rats or mice, and for the birds that nest on the ground there is little or no escape. A tax on cats, similar to the dog tax, might help to some extent, as it would undoubtedly lessen the number of stray cats and prevent them being kept by irresponsible people. If each cat wore a little bell it would save a great many grown birds, as they would be warned of its coming, but this would not save the nestlings. Those in nests on the ground or in low bushes, and even in the tree tops would still be at their mercy, for some cats are great climbers. Neither would it save the young birds learning to fly. These are more often pounced upon by the cat than by any other bird enemy. A cat should never be kept where birds are being attracted, and no bird-lover should own a cat unless he is prepared to keep it in when the birds are nesting. 


\section{B I R D O F P E A E M A R H}

Of the wild four-footed bird enemies some are still left. By far the most clever of these is the fox. However, they also destroy bird enemies, and besides, the poor foxes are hunted themselves. Except in very lonely, far-away places, they are not left long in peace, their skins are too fashionable in the world of humans for life to be a very certain course for them. Were it not for this they would be a serious enemy to the birds, for they are adepts in searching out and catching their prey. They have been known to spring up to catch small birds on the wing. But probably they have done the greatest harm to Partridge and Quail, tracking them to their coveys under the snow.

Mink have been a great menace to the birds along the streams, but they have grown too rare in most places now to do much harm. So long as the value of their fur continues to increase they are not likely to become very numerous in a settled country.

Weasels are one of the worst of the bird enemies. They hunt by scent and are wonderful climbers; moreover, they kill for the sake of killing. However, they prey upon poultry as 
B I R D OF PEASEMARSH

well, and so are likely to be kept in check. Wherever they occur they destroy some bird enemies.

The red squirrel is one of the chief of fourfooted menaces to bird life in cultivated lands. They have been seen devouring both eggs and nestlings. Nearly all red squirrels seem to be bird-nesters. The nests of all small birds, especially those that nest in hollow trees, are at their mercy. Some squirrels deliberately watch the birds to learn where the nests are. Here at the farm they have been known to gnaw the entrance of a wren box until they could enter and devour the eggs. After this tin was put round the openings of the wren boxes, or the trees protected by tin on which the nest boxes were hung. One of the first duties of a Sanctuary owner is to rid the grounds of the red squirrel. 



\section{CHAPTER XX}

THE EUROPEAN SPARROW AS A NUISANCE

$\mathrm{O}$

NE problem confronts every bird landlord. It is how to keep out that persistent nuisance, the European Sparrow.

The farmer bird-lover is more troubled with these pests than any other, for the constant feeding and handling of grain will bring them about, no matter how systematically he tries to get rid of them. These Sparrows were more troublesome here a year ago than they had been for some time before. Possibly this was because the sheep had been kept through the winter at the barn, about which we had been trying to attract the birds, and oats had been fed them out in the troughs in the barnyard. A certain amount of wheat had also been kept at the barn. So, altogether, the Sparrows must have been attracted from neighboring barns, for the summer before we had reduced them to only an occasional pair. 


\section{B I R D OF PEASEMAR H}

It was not until spring, however, that we realized how many had come. During the winter they hid round the barn and sheds and did not trouble the Chickadees and Downy Woodpeckers that came to the window for suet. But with the first indication of spring their aggressiveness began and they took possession of the wood-pile where Chickadee and Downy had liked to come. Later, when the White Throated and White Crowned Sparrows came to us to rest a while on their way to their nesting grounds, and would hop about the door gathering the crumbs we had thrown out for them, the European Sparrows commenced chasing them off. On one occasion when a White Throat braver than the others ventured near, the quarrelsome chattering of the Sparrows brought us to the door, where we discovered that they had simply surrounded the unfortunate White Throat. We scattered the chattering mob and White Throat took refuge in the barberry hedge, and from there made his escape, but it was some time before he ventured to the door again.

We could only promise the White Throats and all the others that we would see to it that 


\section{B I R D O F P E A S M A R H}

another year these ill-mannered birds would not be there to torment them.

"Easier said than done!" said some one who heard our solemn vow to the bird world. And this we, too, learned before the summer was over.

Their next victims were the Chipping Sparrows hopping about the door for crumbs, and when Mrs. Chippie began to build in the barberry hedge, it required constant watchfulness to keep them from tearing down her nest or throwing out her eggs.

All this was a small matter compared with the trouble they caused at the nest boxes. The little Wren houses they could not enter, the opening to admit Jenny being too small for them, so they had to content themselves by sitting on top waiting for her to return from the south so that they could keep her from entering. They had a long wait, for Jenny is a late comer. She is an adept at dodging the Sparrows when she does come, moreover, she is equal to fluffing out her feathers, thus doubling her size, and scolding Mr. Sparrow with much vigor, so we did not need to worry about her. Besides she has been here long enough 


\section{B I R D O F PEA SEMAR S H}

to know that the humans in the house will back her up in anything she does.

But the Bluebird houses and the Purple Martin house were a different matter, as the Sparrows could go in through the entrances of these. It is said that if the nest boxes are placed low enough the Sparrows will leave them alone. Though these houses were placed at various elevations, some as low as they could be for the birds for which they were intended, there was hardly one within sight of the barn the Sparrows could get into that they did not usurp and would have held had they not been driven out or shot, though in many cases they had paid no attention to them until some birds had selected them. Frequently even after they had chosen their own nesting site they would hover round a nest box they did not want, apparently just to keep away other birds.

Their "dog in the manger" attitude was most noticeable with the Bluebirds. They tried their best to drive them all away to the dangers and uncertain nesting-sites of the country beyond. If a pair of Bluebirds came to examine a nest-box, at once a group of Sparrows appeared, and their quarrelsome chattering could 


\section{BIRDS OF PEA SEM A R H}

be heard everywhere. They contradicted the theory that European Sparrows will not go far from the barns. They were at the nest-boxes down the drive, and even those on the elms that lined the road. The Bluebirds in the house by the barn held their own, although they were new comers, but down the drive in a house on a maple near the road, a pair were less fortunate. They built their little nest inside of the house, but before the first egg was laid the Sparrows had worn out their patience. If the Bluebirds left for but the shortest time the Sparrows were in the nest-box and carrying in coarse grasses for a nest of their own. They would fly at the Bluebirds when they returned. Finally the Bluebirds became completely discouraged and with quiet dignity took their departure, leaving the farm with one pair of beautiful, useful birds less, and in their place a pair of worthless nuisances.

We took the house down, finding inside the dainty little nest Mrs. Bluebird had spent so much care and labor upon, and we laid in wait for the usurpers.

A pair of Green and Yellow Warblers trying to nest in a barberry bush in the edge of the 


\section{B I R D OF PEASEMAR H}

lawn had a very similar experience, and there were times when we feared the Swallows would give up and leave. One pair had a specially trying time, as the Sparrows remaining through the winter had taken possession of their nesting place when they returned in the spring. And all this time constant efforts were being made to get rid of the Sparrows.

This is one of the first and one of the most persistent difficulties of those who try to attract the birds, and it has discouraged many a young bird lover, frequently causing him to give up trying to attract the birds or furnishing nest boxes for them, for he sees that his efforts are merely increasing the number of European Sparrows. It is a difficulty which must be overcome if our native birds are to nest near us.

Apart from this the European Sparrow is an objectionable bird about the farms, for it devours much grain in the barn and the fields, especially wheat, a product the country now can ill afford to spare. A reliable ornithologist states that a flock of fifty of these Sparrows will eat a quart of wheat or its equivalent each day.

To rid the premises of European Sparrows [184] 


\section{B I R D OF PEASEMAR H}

is not an easy undertaking and requires both skill and perseverance. It is not work for children or the inexperienced, but should be done by those who know the birds, or serious mistakes may be made. Pulling down their nests is seldom effectual, as they can have another of the rough sort they build ready in a day or so. The winter or very early spring, before the other birds have come back, is the best time to go about it. Poisoned grain is highly recommended as a means of exterminating them, but it is a means to which very few would care to resort. It is a dangerous experiment, too, for without the greatest care something might get the grain for which it was not intended.

Some bird protectors have made the astonishing assertion that they have been able to get rid of these sparrows by giving them grain soaked in strong whisky or brandy. One objection to this was aptly expressed by a nineyear-old boy, who said that it might be all right in town, where there was no place for the Sparrows to hide, but on the farms they would crawl out of sight round sheds and barns and when they were sober they would come out as good as ever after their spree. It is not a dangerous 
B I R D O F PEASEM A R H

experiment. The nine-year-old boy tried it and his little chipmunk got some of the whiskysoaked grain and went on a three-day spree, at the end of which it was back looking for more. Those who advocated using the whisky, however, declared that it caused the Sparrows to leave the premises.

On the whole the shot gun has given the best results and even if used after other birds have come in the spring, they soon learn that it is not being aimed at them.

If one succeeds in getting rid of the European Sparrows a careful watch should be kept for any that may happen to come from other places, for if left alone they will soon increase in numbers again.

It should always be remembered that man is responsible for the presence of the European Sparrow on this continent. Wherever man has interfered with the distribution of nature some harm has been the result. These Sparrows were brought from Europe to the United States about sixty-three years ago. So anxious were some of the people of the United States to get them that on one occasion as many as one thousand birds were sent to Philadelphia in a 
B I R D O F P E A S M A R H

single lot. It is difficult to understand why the Sparrows should have been imported, as there is very good evidence that men were warned against bringing them to this continent. Some ornithologists believe they were confused with the English Hedge Sparrow, which is a wholly beneficial bird in its own country.

Probably the Sparrows were imported by those who are always looking for something new and give little thought to the possible results. In any case the bringing of this bird to this country has wronged the faithful native birds that are working so well for us. Had the men who imported it not been altogether blind to the results of their action, they must have seen that it could never be classed as an insectivorous bird, but was a hearty grain-eater and would aggressively take possession of barns, sheds and stables and drive away native birds. Moreover, they would have seen that it multiplies more rapidly than any other bird, sometimes raising from four to six broods in a year, and each brood consisting of anywhere from four to seven nestlings. In an astonishingly short time it spread over all the United States and Canada. And many a Swallow and [ 187 ] 


\section{B I R D O F P E A E M A R S H}

Bluebird returning some cold spring day, weary from the long, long fly from the south, found the arrogant new-comers in possession of the old nest or nesting-place and were obliged to go off into the wilderness, where there was no protection from their natural enemies.

Since man has brought this trial into our bird world, already filled to overflowing with difficulties, it is man's duty to endeavor to remove it. Bird lovers who are doing a little towards keeping these Sparrows in check are helping to bring peace to the native birds, that by right is theirs.

There is this to be said for the European Sparrows. They are not to blame for being here. They are not natives of this country of long, cold winters. Perhaps this has made them more aggressive and troublesome than in their native land. 


\section{CHAPTER XXI}

ATTRACTING THE BIRDS BY FOOD, WATER AND NESTING MATERIAL

7 HOUGH safety is the greatest attraction that birds can have, they do not know at once that a certain place will be safe for them. Only time convinces them of that. They can readily be attracted, however, by food, water and nesting material. The food must not fail them when the natural supply is cut off, drinking fountains where they can bathe and quench their thirst must never be dry, and the supply of nesting material, which is often very difficult for them to obtain, must be there when they need it.

As to the foods which attract different birds one should be guided by experience. For the insect-eating resident birds, such as Woodpeckers and Chickadees, nothing is better or easier to provide than a bit of suet in some sheltered spot where they will be safe from cats when feeding upon it. But for most birds [ 189 ] 


\section{BIRDS OF PEA SEM A R H}

the best sort of food and that which can always be relied upon, for its being placed there is not dependent upon the memory of some human being, is the natural food for the birds, that grows upon the ground or on bushes, or trees or shrubs. Unfortunately, this is sometimes very hard for the birds to obtain. The clearing of the land has wiped out such bushes as sumac and elderberry, and such vines as bittersweet and the wild clematis that in old days filled many of the fence corners, making these as well as a haven of safety for the birds, an abundant food supply which seldom failed. Some of the berries were likely to hang on all winter, and to be there when the migrating birds returned in the spring, so that they could always fall back upon them if they were overtaken by an untimely storm and unable to get anything else.

Bird lovers are beginning to realize the importance of planting in their sanctuaries the wild shrubs and vines that provide food for the birds. Barberry bushes and mulberry trees are two of the most attractive. The mulberries ripening so gradually provide a dainty change for the birds for many weeks, and the barber- 


\section{B I R D OF PEA S E A R S H}

ries hang on until the leaves are green in the spring, and seed-eating birds will come to them and feed upon the seeds in the berries when a late snow storm has covered all other supply of food.

One bird lover instituted what he called a bird food tree, which was a great success. He heated a certain amount of fat, putting in it seeds and chopped nuts of different kinds, then, selecting a small bushy evergreen, he poured the mixture over it while it was still hot and it congealed on the tree. The birds could take from this whatever part of the food they wished. The result was that many stayed to nest near the food tree that had been such a bonanza to them. It did not decrease the value of the birds in the slightest; they went about their work among the leaves, the branches, or the trunks of the trees, or hunting insects on the ground just as diligently as they had done before, but it kept them working near by. Such a food tree in every sanctuary would attract valuable birds to the sanctuary and might save the lives of many. The winter birds which are always at the mercy of the elements, are very easily chilled when they can- 


\section{B I R D O F P E A E M A R S}

not get food, and the migrating birds coming early are often overtaken by storms that clear the air of insects, or freeze the ground for days at a time so they cannot get enough to keep them alive.

Studying bird life, one finds that in their natural state the small ponds and streams attract the nesting birds. Every year it has become more difficult for birds to find safety and a nesting place where there is any chance of getting either a drink or a bath. With the clearing away of the woods, springs and streams have dried up, and the larger rivers that have survived the change flow through the towns or the farm lands, and the trees on their banks are becoming few and far between.

Swallows always choose in preference a barn beside which there is a spring where they can drink and bathe and get the mud with which to plaster their nests. It was their appreciation of the spring at one of the barns that made us think of supplying a drinking fountain. Our first attempt in this direction was a pan of water in the middle of a nasturtium box on the lawn; and here the birds flew in among the flowers and drank and splashed. The Peewee 


\section{B I R D OF PEASEMAR H}

and the Song Sparrow, the Goldfinch and the Robin and the Catbird bathed there, and the whole family of Flickers, one after the other. When they had finished with their baths all the water was splashed out. With just this one little pan we could not keep them supplied. They would have it empty before we were up in the morning, and most birds wanted to bathe morning, noon and night. Then we considered how we could make for them a more permanent bath. One day, when walking among the old stumps and fallen logs on the flats beside the bush, a bright idea came to us. Why not take one of those big stumps and stand it upside down? The root ends extending out would make perches of all sizes, and the centre could be hollowed out and lined with cement so that we would have a very natural drinking fountain that would not leak. Here the birds could splash to their heart's content, and then dry and sun their feathers on the perches about it. So a stump was selected and brought up to the lawn. The drinking fountain made in this way won the immediate approval of the feathered tribe.

In making a drinking fountain it should be [ 193 ] 


\section{B I R S OF PEA S E A R H}

formed so that there are different depths of water; a small bird would not bathe in the water required for a large bird. Little shallow places at the edge should always be left for the small birds, while the centre might be several inches deep, in which such birds as the Flicker would not hesitate to enter. The surface should not be too smooth, as that would make it slippery. Where it is lined with cement this should be left a little rough.

A very satisfactory drinking fountain has been made by hollowing out the top of a bit of tree trunk that had been left a couple of feet high when one of the shade trees had been cut out. Some prefer to make the drinking fountains on the ground, but such a drinking fountain should never be among shrubs or long grass, as a cat might come up unseen and spring upon the birds when their plumage was drenched and heavy. A drinking fountain never fails to increase the number of birds that nest about the house.

Food and drink are not all that the birds require. Simple as their wants are, they must have something more than that, if the babies are to be housed in comfort. It was not many 
B I R D O F P E A S E A R S H

springs ago that a Robin spent one long morning tugging at the fringe that edged a towel on the clothes line. The next year their wants were anticipated, and a supply of nesting material put out. Shop twine, cut in small pieces, cotton batting, and bits of wool are readily gathered up. The wood-pile is the place they seem to like best to come for their nesting material. Quite by accident some string was thrown out there, and while at breakfast the next morning, we watched an Oriole tugging and pulling at a long piece that had twisted around a knot on a bit of apple wood. It got it off at last and flew away with one end of the string in its beak, the other floating away behind it. After that strings and bits of paper were put on the wood, and a fresh supply had to be put out every few days in the nest-building season. The arrival of a flock of sheep was a great help to the birds, for nothing could give a warmer lining to their nests than the wool shed on bush and fence. One hot day in June, a Robin was seen carrying great beakfuls of wool from the barnyard up to her nest in the aspen. She had been unfortunate in her first nest and was obliged to build again, and lined [ 195 ] 


\section{B I R D S O F P E A E M A R H}

her second nest with wool, even though the summer weather had come. It is really very difficult for birds to find the nesting materials they need, and where this is supplied to them they are sure to make their homes in greater numbers than they would do otherwise.

Food, drink, and a bit of string with which to weave their nests are very simple wants indeed, and he who supplies them for the birds will be repaid many times over. 


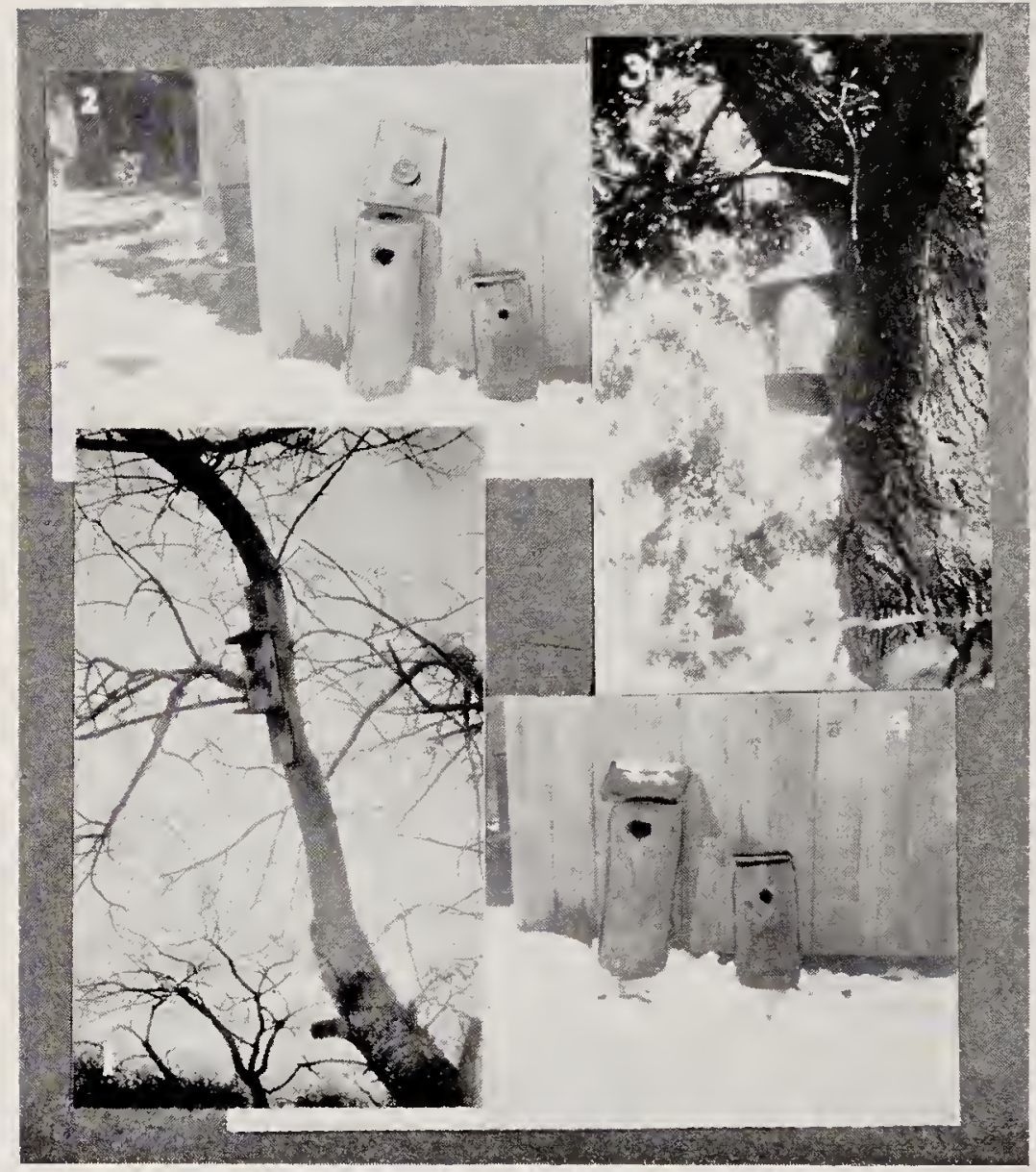

1. Nest box attached to board and nailed to tree. (Page 197.)

2. Roof, with plug to hold it in place. (Page 191.)

3. Nest box, with straight hollow. (Page 193.)

4. Nest box in Fig. 2, with roof adjusted. (Page 191.) 


\section{CHAPTER XXII}

HOW TO MAKE AND HANG NEST BOXES

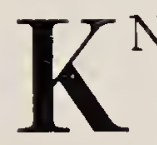

NOWING the difficulty birds that nest in hollow trees have in finding nesting places, one realizes that unless they are helped in some way they will be forced to leave altogether. Fortunately, with very little trouble, nest boxes sufficiently like their natural nesting places can be supplied to them. Every year it is more and more impressed upon us that this is the only way to keep these birds with us. Great pleasure and profit will be derived from this means of inducing the birds to come near us and make our gardens and orchards and fields take the place of the woods and swamps of long ago.

In order to make nest boxes with success one must study the natural homes of the birds and the surroundings they most desire. To induce the birds to inspect the nest boxes these should appear as much as possible like their natural [ 197 ] 


\section{B I R D O F PEASEM A R H}

homes, and the interiors should be like them or the birds will not remain and nest in them. Painted decorations should never be used.

Birds that do not build a nest inside the trees but burrow in the decaying wood, their peckings forming a soft lining, are more difficult for the inexperienced landlord to supply with acceptable nest boxes.

Here we have found that a cross section of a cedar log or apple wood, that is the large limbs cut off in pruning time, that had decayed in the centre, is the best thing out of which to make them. The section of log can be split in order to bore out the hollow. This should be shaped like a flask, rather pointed at the bottom, but filled in with some sawdust, an inch or more deep, according to the bird it is intended for. A Flicker should have about three inches of sawdust, but a smaller Woodpecker does not require quite so much. The entrance for the Flicker should be two and a half inches in diameter, while for a Woodpecker two inches is sufficient. The burrow should be deep enough below the entrance so that a cat can not reach her paw down to the nest. 


\section{B I R D O F P E A E M A R H}

The top of the section of $\log$ should be cut with a slope, and the entrance for the bird made under the lower side. A piece of weatherbeaten board makes a very good roof. Projecting over the entrance it will slope downwards and carry off the rain. If the cavity goes down to the bottom of the nest box a floor of board, like the roof, can be nailed on; this will allow sufficient drainage, but where the cavity does not go the full length of the cross section and no drainage through the box is possible, a little more sawdust should be supplied.

We have learned by experience that a roof that can be lifted up so that the nest box can be inspected, is a great advantage. If birds refuse to nest a second time in a nest box the cause is sometimes found by examining it. In one case a decayed egg was the reason. By lifting off the roof this could easily be discovered and removed. Sometimes wasps get in and their nests need to be cleared out. Last summer a young Bluebird died in one of the boxes. The old ones removed it themselves, but had they not been able to do so they could not have nested there another year, unless it had been discovered and removed. So there are many 


\section{B I R D O F PEA SEMARSH}

advantages in a removable roof. Small hinges at the back and a hook in front so the roof will raise like a trap door, can be used, but fastened thus it will not always remain perfectly tight, as high winds frequently loosen hook or hinges. We have found that a plug that just fits into the excavation at the top of the nest box, fastened under the roof, is the simplest and most satisfactory way of holding the roof down.

Flask shaped excavations are not easy to make and require special machinery and much labor. Fortunately the birds can be induced to do the work for themselves, and their beaks are the best of tools, if the wood is suitable. A section of an old log, decayed in the centre, can be cut in the same way, and an opening for the bird's entrance started in it. It can then be hung on a tree in place of a finished nest box. The Flickers, if they find other requirements desirable, will burrow it out to suit themselves. The idea of trying this experiment came after examining an old apple tree they had been working on. They evidently thought, from the decayed spot at the top, that the trunk was decayed all the way down the centre, and had [200] 


\section{B I R D O F P E A E M A R S H}

commenced making an opening. For hours a bird would remain stationary on the tree working at the hard apple wood. They had bored in almost two inches when, finding the wood still perfectly firm, they gave up. As the boys said, they knew now it was not rotten all the way down the centre and that they could not burrow out a nest. When birds will start boring into an apple tree upon so slight an indication of a possible nest, they would readily bore into a piece of cedar log, if an opening is started so that they can see the rotten centre, and burrow out their own nest, in which they will be very much at home. Our Flickers refused to nest in nest boxes we bought as an experiment, though they examined them. Nor would the Bluebirds, or even the Wrens nest in them. The Wrens filled one of them with dead leaves, but live in it they would not. As the Wrens are so adaptable, it must have been because more natural houses were available.

The most successful bird houses we have had have been those made out of cedar logs or apple wood, and the flask-shaped cavity is usually a first choice, even with Bluebirds and Tree Swallows that build nests inside the houses.

[201] 


\section{B I R D O F P E A E M A R S H}

But such a cavity is not necessary, for these birds will build their nests in houses which are hollowed straight down. The house in figure 3 in illustration was made in this way.

Our first Bluebird house was just a small grocery box, over which the boys tacked bark to cover the newness of the wood and give it a more natural appearance. The birds nested in it the first summer, but the following spring, when houses made of hollow apple wood were put up, they removed to one of those. Having studied the birds since then, we fear they were very uncomfortable and unsafe in that first house, and hard-pushed for a nesting place to have accepted it at all. It was draughty and hung on the tree up among the branches where, when the leaves came out, it was in perpetual shade, and the entrance was big enough to have admitted a squirrel or a small cat.

If the houses for these birds are made of boxes they should be firmly held together, with no draughty corners. The opening for the Bluebird should be not less than an inch and a half in diameter. This is the size always given, though we have found that just a trifle [202 ] 


\section{B I R D OF PEASEMAR H}

over is more satisfactory. As someone has suggested, the Georgian Bay air may make the Bluebirds a bit plumper. For the Wren, just an inch and a quarter is sufficient.

Of all birds Jenny Wren is the easiest to suit with a home. She has nested here in boxes of various shapes and sizes, from houses made from sections of hollow wood, to little tin cans, simply fastened up, with the proper openings made in them. One little Wren house had a chimney on the top, and the father bird delighted so in singing on the chimney that a long lath was nailed up at another nest box, and an hour later the Wren living in that house was perched on the top of it singing at the top of his voice.

Once we made a sad mistake. Pet, the Shetland pony, had just been clipped and somebody thought that the thick, long black hair would be just the thing for the birds to line their nests with, and accordingly put a handful of it in several of the nest boxes. The birds declined to locate in those houses. One very quaint little wren house, made out of a bit of hollow pump log and fastened against the stone wall, contained a little bit of it. The house and loca- 


\section{B I R D O F PEASEMAR S H}

tion were ideal. But that hair! It was examined by no less than three pairs of Wrens. They seemed to consult among themselves about it and then they went away. Evidently the birds took these houses that contained the hair to be the haunt of some little animal of uncertain character and were afraid to occupy them. So we learned that if birds wish to use hair off any animal they prefer to carry it in themselves. They know then that the owner of the hair is not coming back to claim the house and perhaps devour their offspring.

If the property where the birds are being provided for has not an abundance of trees and bushes of all sorts, where the Robins would be sure to find proper branch formations for their nests, shelves could be put up for them. Our experience has been that they prefer proper branch formations, of which there are an abundance here. If shelves are made they should be at least six inches wide, and if placed under the edge of a roof they should not be too close to it. If they have roofs of their own it is important to make these high enough, for when feeding the nestlings the birds stand on the edge of the nest and sometimes have the 
head raised, as the young will stretch up their necks for the food when they know the mother is coming. The roof, like all bird house roofs, should slant and project to keep out the storm.

Smaller shelves can be supplied for the Phoebes, unless there are plenty of nesting places for them.

In choosing locations for nest boxes and in hanging them, the taste and requirements of the birds must also be considered if one wishes to have success. The Flickers like to be in the orchard or along the edge of the orchard. The Woodpeckers here prefer the edge of the orchard, or the edge of the bush below the orchard bank. Bluebirds will be at home round the farm buildings or the house, especially if there be an old orchard and stretch of uncut grass close at hand. The Chickadees have been most at home in the trees at the edge of the swamp, though they spend much time in the orchard, which is only a short fly from the swamp, and some nest in the orchard. The Tree Swallows prefer to be near a spring, and the little Wrens will come as close to the house as they possibly can.

Various means may be used to fasten the [205] 


\section{B I R D OF PEASEMARSH}

houses to the trees. They may be nailed on a board projecting above and below, and the board nailed to the tree. Another way is to put a strong hook in the tree and a ring on the top of the bird house and simply hang it to the hook. A small hook at the bottom will keep the house from shaking.

If the branch or tree trunk, to which the house is attached, bends in the slightest the house must be hung on the under side. By observing the natural holes of the birds one finds that they never slope upwards, as this would let in the rain and sun. Some are on a perpendicular trunk, but if it slopes they are always on the under side. A house hung with the opening facing upwards would probably remain unoccupied.

The particular places on the tree trunks where the houses are to be hung should be chosen while the foliage is on the trees, otherwise when the leaves come out they may be too shaded. Birds require an exposed, or partly exposed tree trunk, where they have plenty of sun and air. The hollow trees of their natural homes are dead, or partly dead, and the foliage never very thick. A post or pole near trees is [ 206 ] 


\section{B I R D O F PEA S E A R S H}

one of the best locations for a nest box, and is usually easier to protect than a tree.

The bird landlord must not forget to protect the trees on which the nest boxes are hung, so that cats, squirrels, weasels or other fourfooted enemies of the birds cannot run up to the boxes. A very easy way of doing this is to put a piece of tin round the tree trunk. If fastened to the tree in the form of a cone quite a small piece of tin will answer the purpose. This should be high enough so that a fourfooted creature could not jump from the ground to the trunk above the tin. The trees thus protected should stand apart from others, so that a squirrel could not reach a box by jumping over from another tree. 



\section{CHAPTER XXIII}

\section{NESTING SITES}

$\mathrm{E}$ have seen how much the birds that
nest in hollow trees have been affected by the clearing of the land, but the birds that nest in trees and bushes, and even those nesting on the ground have found great difficulty in obtaining such a spot as they require to build their homes and rear their families. Dozens of incidents among these birds show how much they are in need of suitable nesting places. One in particular was told by an old gentleman, a pioneer of early days, who had lived many a summer with the birds. The story was of a pair of Robins that could not find the particular formation of branches that would give them a suitable crotch in which to weave their nest. Not far away was a station yard in which scraps of binder twine were being thrown about. Back and forth the Robins flew, carrying this twine to a [209] 


\section{BIRDS OF PEASEMARSH}

particular spot, where a rake handle rested in the branches of a willow tree. The strong twine thus secured was then woven with infinite care in and out between rake handle and branches, and over this foundation of binder twine the nest was built. Mrs. Robin did the building, but Mr. Robin stayed near, fought away the European Sparrows, and saw that she was not disturbed. The old gentleman specially liked to tell that when the rake was needed his wife said he might buy or borrow, but disturb the Robin he should not.

We look about at the trees and naturally think the birds have plenty to nest in, but if we knew more of the requirements of the birds we should understand that if they are not in a certain place, it is because for some reason it is not suitable for them. Possibly they cannot get the branch formations they require, or the shelter or the privacy they need, or they would be too far away from water or from food. A successful bird landlord must study the conditions the birds require. The cutting down and pruning of trees, the clearing away of bushes and shrubs, the removing of the old rail fences and the overgrown fence corners has de- 


\section{B I R D O F PEA E M A R H}

prived many of the birds of nesting places, or the necessary surroundings for their homes.

Every year several pairs of Orioles have nested here, and they are seldom known to hang their nests on any tree except an elm, though they have a choice of numerous kinds of tall trees. There seems to be something in the way the high branches of the elms curve over at the tip that answers the requirements of these birds.

Unfortunately these graceful trees are not so numerous in some country places as they were. The idea seems to have spread among some people that they are in some way detrimental. They will tell you most positively that the elms take all the moisture out of the ground for an astonishing distance round about, and that if they grow along the road-side they will spoil the crop half way across the field, or give other objections equally absurd. And so where the land has passed into the hands of those less intelligent and less experienced, the elms have decreased in number. These beautiful trees, left by the pioneers for their shade and their protection, have in recent years been cut down to an alarming extent by the more ignorant of 


\section{B I R D O F PEASEMAR H}

the land owners, who do not know the injury they are doing to themselves and to those about them, and to those who come after them.

The very fact that the elms attract the Orioles should be in itself enough to save them. These birds are friends which farmer and fruit grower cannot afford to lose. Living as they do almost altogether on leaf-eating insects and caterpillars, they probably destroy more of the moths that lay the eggs in the trees than any other bird. Unfortunately, however, they are not very numerous. Possibly the decreasing number of suitable trees on which to hang their marvelously woven nests has much to do with this. To preserve the elms and supply the birds with nesting material might help to bring them back in greater numbers.

The decreasing number of sheltering elms, the Oriole's chosen nesting place, is significant of the difficulties that other birds have in finding the trees in which to nest. Preserving groups of trees and groups of bushes at different places on the farm will do much towards increasing the number of birds: One tree standing alone, or one solitary bush is blown about by the wind, giving no shelter from [212] 


\section{B I R D O F P E A S M A R H}

storm, and a nest built there is exposed to the view of the bird enemies. The winds and the prying eyes of bird nesters are the very things from which the birds require protection.

The extensive cultivation of the country has interfered much with the birds that nest on the ground. In many places it is difficult for them to find the tall rank grass that shelters them, or the stumps and stones beside which they like to make their homes. Those that nest in the meadows are in constant danger from agricultural implements, or from the trampling of the stock. Many accidents to the nestlings are unavoidable. But much might be done for their preservation if some spot not necessary for cultivation were left for them and the grass allowed to grow tall and rank. In a surprisingly short time the birds would learn that this spot was safe and many would make their homes there. Tall, rank grass or brush heaps, are a great attraction to the Song Sparrow. Here in the orchard when the brush, after pruning, is piled in little heaps, it sometimes happens that before they can be burned some member of the Sparrow family is making a home in one of them, and so that particular 
B I R D O F PEASEMAR H

little brush heap must remain where it is all summer.

The birds that nest in swamps and beside the streams, have had the hardest time of all these last few years. The pretty bits of bush are disappearing, and with the going of the trees, springs and streams and marshes are drying up. In some cases this land is useless for agriculture and becomes only an exposed bed of weeds, where once among the ferns and grasses and fallen leaves the Woodcock or the Crane, or our favorite, To-whit To-whee, made their homes and reared their families.

The value of the birds as insect destroyers, their beauty and their cheerful songs are well worth the preservation of the nesting places that bring them back spring after spring from their far-away winter homes.

When the maples and elms and willows and aspens have been left for the birds one might consider the pruning of shrubs and shade trees, so that they will grow in such a way as to provide the branch formations that the birds need. Just by accident one way of doing this was discovered. The top branches of some of the apple trees had been cut back, the next year a little [ 214 ] 


\section{B I R D OF PEASEMARSH}

circle of suckers had grown up from the cutback ends, and the pruning of them that spring was neglected. When the leaves were off in the autumn we saw that in places where this branch formation occurred Robins had built their nests. We tried this with a chestnut tree beside the window and soon had a happy Robin's family.

Much can be done to help the birds by tying branches of shrubs and bushes in such a way that they will form foundations for the nests, and if some corner on the farm is left where sprouts of trees and shrubs grow up at their own sweet will, it will be a boon to some rare birds. In a little thicket here left for that purpose, we knew the Indigo Finch was nesting, for we had seen his mate carrying in nesting material, but not until the leaves were off did we see the nest on a little cross branch of a locust sprout, not two feet from the ground. Such a branch formation so near the ground, where there is plenty of surrounding cover, is readily accepted by these birds.

A thicket of shrubs, especially if old stumps and tree trunks are there and the grass left uncut, is a great attraction to all birds. It is a 


\section{B I R D S O F P A S M A R H}

real help to the small birds that nest on the ground, and a means of keeping them at our very door. To-whit To-whee always likes a fallen log or stump beside which to make his nest. Many other members of that family, and members of the invaluable Warbler family, would readily nest in such a spot. On one farm the Whip-poor-will always chose the rhubarb bed on which to lay her eggs, probably finding that the large leaves of the rhubarb gave the privacy and moisture of the woodland.

The birds that want a swampy home, preferably beside some pond or stream, are the most difficult to help. Their troubles are a plea for the preservation of the bushes that grow along the streams, in the swamps and on the hillsides. We cannot bring back those cool, shady places that have gone, but we can do what we can to induce the owners to leave what remain to the birds.

The birds that nest in swamps have had more difficulties in obtaining nesting places than the shore birds, for the shores have not been deprived as yet of so much of their natural condition, and the old nesting places on a sheltered beach have not all disappeared. But 


\section{B I R D OF PEA S E A R H}

unfortunately they are not so safe as they were before the days of motor cars and motor boats. More seclusion and greater protection is the best help that these birds can be given. 



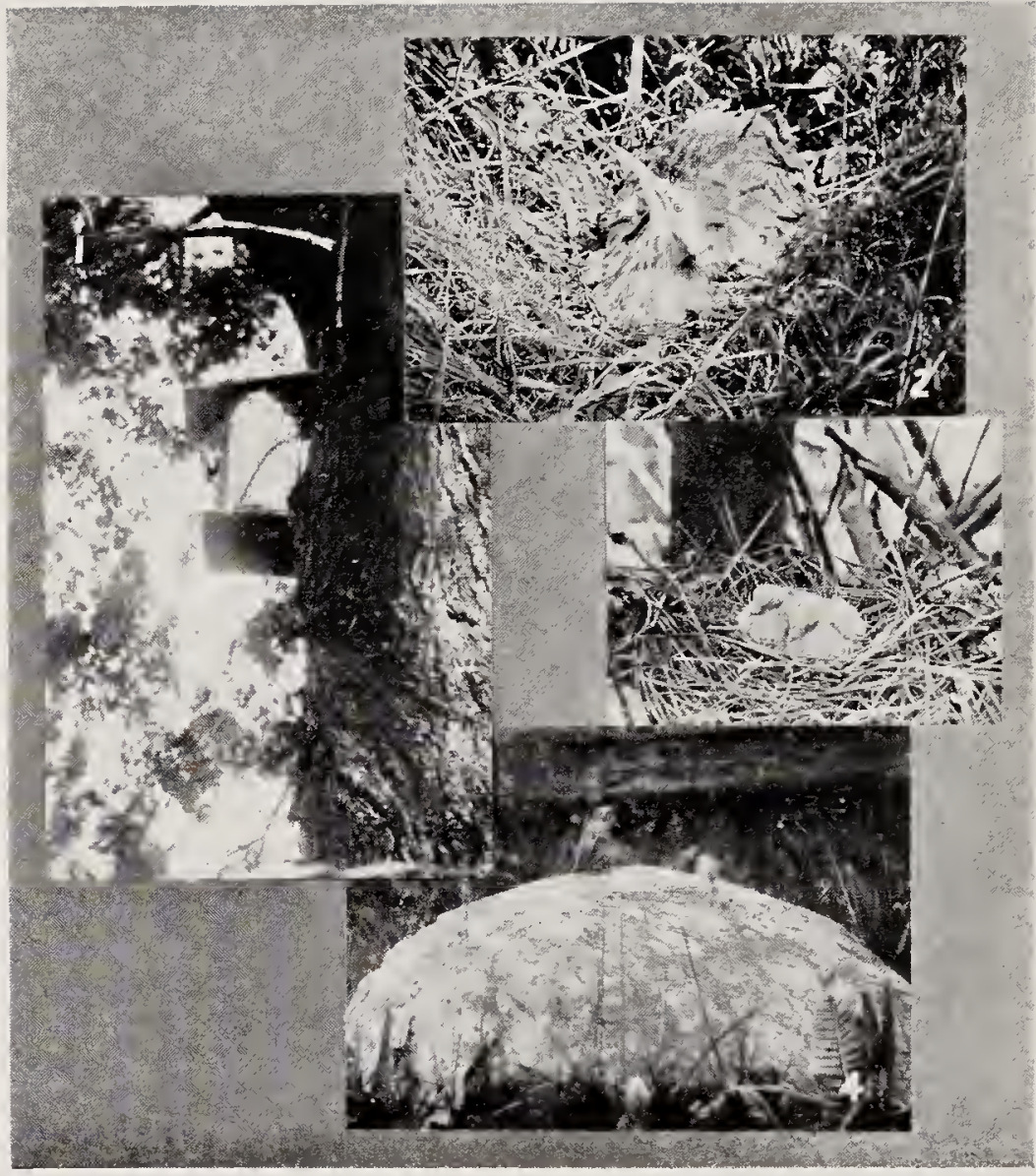

PHOTOS FROM THE S.INCTUARY

1. Father Bluebird at nest box. (Page 52.)

2. The Bittern on her nest. (Page 115.)

3. Baby Mourning Doves. (Page 100.)

4. Baby Bluebird the day it came out of nest box in Fig. 1. (Page 54.) 


\section{CHAPTER XXIV}

\section{BIRD SANCTUARIES AND BIRD CLUBS}

T $\mathrm{T}$ is remarkable how many prospective Sanctuary owners disregard altogether the tastes and simple requirements of the would-be feathered tenants. Only yesterday an individual was talking glibly of his plans for a newly acquired possession, a few acres of land along the shore, where hitherto the trees and bushes, the vines and reeds and waving grasses had grown in wild profusion. Among them many a bird had found cover, food and home. Now the new owner dilated on what he would do to this spot of rare beauty. He would cut those reeds and vines and all the tall, waving grass; he would trim the over-hanging branches of the trees. But his crowning triumph was to be at the mouth of the stream. It was where the Bitterns and Cranes and Herons had fished from time immemorial. Kingfisher nested in 


\section{BIRDS OF PEASEMARSH}

the bank, and Redwing in the overhanging bushes. The new owner would cut away those bushes, alter the bank completely, and make the place a harbour for motor launches.

"And then," he added, with a triumphant wave of his hand, "we will have it made a Bird Sanctuary."

It would indeed require a printed notice to show for what the place was intended. The birds would not weave their nests in those poor trees trimmed to spindling proportions. The shy Blue Heron would not come to live where pleasure launches had taken the place of reeds and bushes. The world of arrogant humans might say he had improved the place, but the wild things would go. As a bird sanctuary it would be as desolate as the house when the wedding guests were gone.

Very different is a real bird sanctuary, with its cool, shady retreats, its sheltering bushes and its profusion of dogwood and sumacs. It needs no printed notice to make known its purpose, hundreds of feathered songsters will proclaim its name. A visit there is an inspiration. Birds have nesting places, they have learned they are safe and that the food supply will not 


\section{B I R D O F P E A E M A R H}

run out, and so they have returned spring after spring, bringing others with them.

To obtain success, however, a sanctuary, when once established, should be carefully guarded. It is just as important to retain as it is to gain the confidence of the birds. The experience here shows that every sanctuary should be established on a permanent basis. Increasing the number of birds will increase the number of bird enemies, unless these are constantly kept down. To attract birds to any spot and then, when they have learned to know the spot as a haven of safety, to cease to give them the protection which made it safe, may result in more loss of bird life than if the sanctuary had never been established.

Much as one sanctuary in a district can do, it has its limitations. The birds do not know the boundary of the sanctuary and accidents may befall them when they are beyond its limits or passing on in their migratory flight. Especially has this been the case with game birds, numbers of which have so often been shot when passing on from a sanctuary where they have fed and rested. A line of sanctuaries that provide food and resting places for birds in 
B I R D OF PEASEMAR H

migrating would be a great factor in the preservation of migratory game birds. The experience of sanctuary owners proves that the birds readily learn that certain places are safe for them.

On the Miner farm in Essex County, Ontario, the most remarkable Wild Goose sanctuary on the continent, many hundreds of Geese come every April and rest on their journey to the north. Inside the sanctuary limits even a stranger may walk within a few feet of them without alarming them, but out on the lake, just two miles away, a boat could not get within half a mile of one of those Geese. On the lake they know they may be shot, but they have learned that inside the sanctuary they are always protected. It seems that birds must have some means of communication with other species, for during a spring migration while the Geese were resting there a flock of wild Swans flew over and circled round. It was as if the Geese had told them of their haven of safety and they had come to see it for themselves.

In choosing a place for a sanctuary where large, rare birds or game birds are to be attracted, it is important that it should have the 


\section{B I R D OF P E A E M A R H}

natural conditions that the birds require. Some birds have grown so suspicious of man that a sanctuary for them must be in a very solitary spot, at least until the birds have learned that they are being protected. Mr. W. E. Saunders, in a paper read before the Committee of Conservation, made the wise suggestion that places where these rare birds are found to be nesting should be made sanctuaries. In speaking of the Great Blue Heron and the Pelican, he says, "Some birds do not like people to make a fuss about them, and that refers particularly "to large wild birds, on whom human friendship is suddenly thrust. I had a remarkable experience along that line in Alberta. On a small island in Miquelon Lake, twelve miles north of Camrose, there were two hundred breeding pairs of White Pelicans. The Pelican, a bird about the size of an Eagle, is not accustomed to human interference. I visited the island with a friend and saw these two hundred nests, but the birds left the island before we landed and did not return for about an hour or two after we left. My companion was an enthusiastic ornithologist and bird protectionist, and his next door neighbor was the local M.L.A. 
BIRDS OF PEASEMARSH

Through his influence that island was declared a bird reserve and the nearest farmer a game warden, his duty being to see that the birds were not molested. He visited the island practically every day and the birds resented it so much that, since that year, there has not been a Pelican on the island. That shows that we must be careful in our attitude towards some of the wild birds.

"The Great Blue Heron used to nest in communities, and, while it does to a certain extent, the communities are very small. There is one heronry near London with about twenty odd nests. How it has escaped so long I do not know, because we have so many irresponsible people who do not think, whose impulse is to slaughter, and who go out with .22 rifles into a heronry just to see how many Herons they can kill. Then, of course, the eggs rot or the young starve to death. ... I do not see why it should not be possible to declare such places as heronries bird sanctuaries where guns would not be allowed, where special penalties would be enforced on any person going with a gun. As a rule the few places in which these heronries now exist are places where the neighbors [224] 


\section{BIRDS OF PEASEMARSH}

are favorable to the birds because, if that were not so, they would not have lasted nearly so long."

But even these shy birds may become unafraid of man, though it may take years to establish their confidence, for to what the birds once were they will return. The Pelican has been persecuted by man, and being a bird of rare intelligence, distrust of human beings has descended from generation to generation. When the white man first came to the country and firearms were unknown, the feathered creatures were not easily alarmed. Records of the early explorers show that of the large birds, some already extinct, some now the shyest and the rarest, showed not the slightest alarm at the approach of man, some even crowded about them and exhibited considerable curiosity and interest in the newcomers. This confidence can be regained. Individuals can do a little, but without co-operation there is danger of much of their work being undone.

The sanctuaries and bird clubs together can readily increase the bird population and save from extinction those large, rare birds that are already going. The sanctuary will give a safe 


\section{BIRDS OF PEASEMARSH}

home to the birds that remain to nest, and a resting place to those that pass on to nest farther north, and the bird club will protect the birds beyond the sanctuary gates. But the bird club must not be confined, it should be broad and far-reaching as the land where birds abound. A bird club that remains a small society composed of its founders and their friends, or those whom they wish to have as members, cannot do any great amount of good. And as the largest proportion of birds are found on the farms, active bird clubs should have an active farm membership.

A wide system of bird clubs could be made a very complete factor in the protection of our birds. Such a system should be international, otherwise the birds might be protected in one country and decreased in numbers in another. If such a society had its headquarters in some large centre, with a branch in each county, which had still smaller branches in each township or locality, these branches including bird societies of the school children, and each society pledged to protect the desirable birds, giving them shelter, nesting places, food where necessary, and protection from their enemies, 


\section{B I R D O F P E A E M A R S}

including Crows and Blackbirds and cats; and each society also pledged to make reports to their central branch, which in turn would report to the International Centre, a very great deal might be accomplished and some systematic record kept of the work for the birds and its results.

No bird could then decrease very rapidly in numbers without this being known at the centre of the bird protection work and prompt, far-reaching measures could be taken to prevent it from vanishing from the earth. 



\section{CHAPTER XXV}

\section{"LITTLE FEATHERED BROTHERS"}

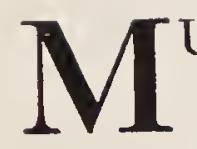

$\mathrm{UCH}$ as the birds have done to guard the products of the country, they have rendered a still greater service to the world. They have a value that cannot be weighed by abundant crops or verdant woods. It reaches beyond material things. From the earliest times the birds of the air have been an inspiration to the human race. Their influence has come down through the ages.

Before the days of the white man the Indians watched and marvelled at the ways of their "little feathered brothers," and the influence of the birds upon them is shown in their legends and in the speeches of many of their great chiefs.

The influence of the birds upon the white man on this continent dates back from the first voyage of Columbus. Had it not been for the land birds that passed them his discouraged men might have forced him to turn back when almost in sight of land. 


\section{B I R D OF PEA SEMAR H}

How it must have cheered Jacques Cartier in the strange New World to find, as he tells in his relations of his voyages, "Cranes, Swans, Wild Geese (white and gray), Ducks, Thrushes, Blackbirds, Turtles, Wild Pigeons, Finches, Redbreasts, Nightingales, Sparrows and other birds, even as in France."

When Sir John Franklin was on his last journey overland to the Arctic, he wrote of their delight at the return of Swans, Ducks and Geese, giving the first indications of spring after the long, cold, dark winter they had been forced to spend in the northland. When travelling down the Coppermine River, almost within sight of the northern ocean, he was serenaded by the many birds that were going to their nesting places. On July 11, he mentions in his diary the Ducks and Snowbirds that were nesting there, giving life to the dreary wastes.

Frequently birds were invaluable guides to the explorers travelling in an unknown country. "Late in the evening, as we descried the Ravens wheeling in circles round a small group of poplars, and according to our expectation we found the Indians encamped there," 


\section{B I R D O F P E A E M A R S}

Franklin tells of one occasion when to find the Indians meant life to his party.

As guides birds have been perhaps of the greatest service at sea. Many a fisherman caught in a dense fog or a blinding storm would have had no idea in which direction to steer his craft had there not also been some feathered fishers out that day; and no fog was too heavy or storm too black to confuse their sense of direction. No matter how far they had gone out to sea they knew which way to fly to their nests on the shore, and the poor lost human's craft could follow the birds to safety.

Though in these modern days when milestones greet us at every turn and every craft has its compass, we seldom require the services of winged guides, but we need, as the world will always need, the inspiration of their presence and their songs. Few there are who have never gone out into the garden or the orchard or the woods, sad and lonely and discouraged and come back with fresh hope, fresh energy, fresh joy because some tiny songster was pouring forth in sweetest notes its message of encouragement to man.

Once in a mining country far away among [231] 


\section{B I R D O F PEA S E A R S H}

hills and rocks, where few birds came and went, a group of men had gathered in a sheltered nook. They were men who had staked their little all and lost. The shadow of despair was over them. They had no heart to face the world. Then, suddenly, there poured forth from the tree tops above them a bird's song, sweet, rich and joyous, a song they had last heard in the gardens of their homes, a song that was blended with every memory of their childhood and every aspiration of their youth, and as they listened it came to them that all the better things of life were left to them. That glorious song that had come so unaccountably in the moment of their need, gave them back their own.

Shelley calls the Skylark an embodied joy, whose song is,

"Better than all measures of delightful sound, Better than all treasures that in books are found."

Our own Bobolink has one peculiarity of the English Skylark, it sings while it flies. Often when walking through the meadow the song of the Bobolink, like silver bells, comes down 


\section{BIRDS OF PEASEMARSH}

from over our head. And Bobolink sings his "bob-o-link" in sweet, sweet notes that no human being could imitate. The birds have the soul of music. If the world were deprived of this it would be deprived of one of its noblest inspirations.

THE END. 
ARMAC PRESS, LIMITED, TORONTO 


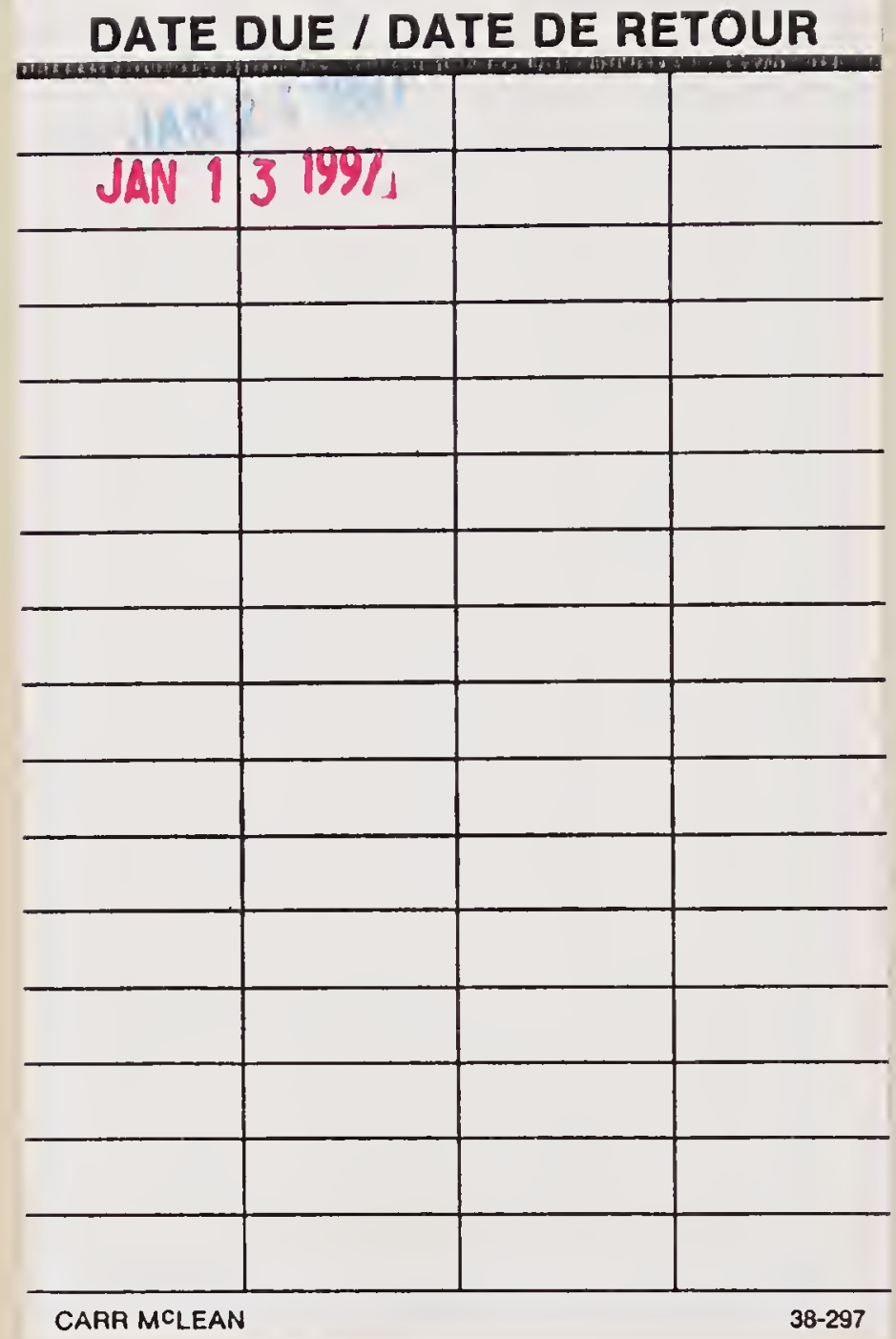




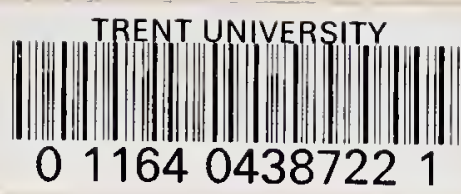




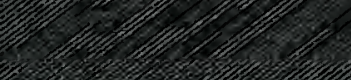

1

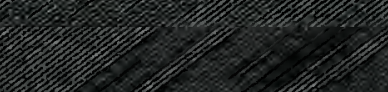

6. 2038

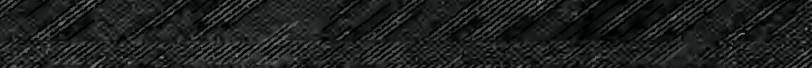

2010

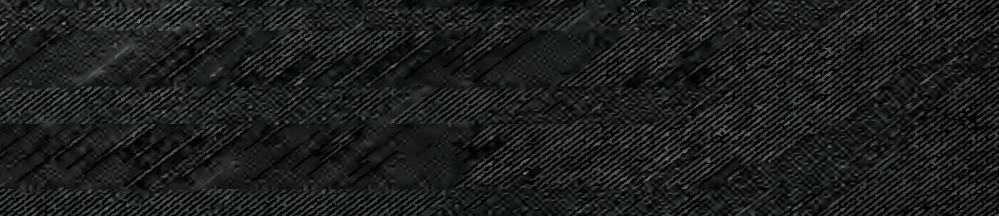

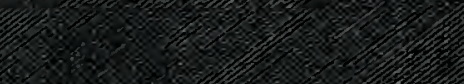

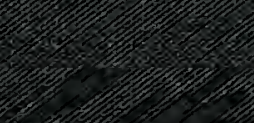

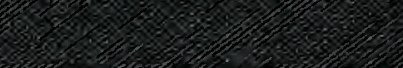

$\operatorname{lis}_{0} \times 5$ 